\title{
Do CEOs' Outside Directorships Affect the Performance of Their Own Firms?
}

\author{
by \\ Pengcheng Zhu
}

\author{
Submitted to the Graduate Faculty of \\ the Joseph Katz Graduate School of Business in partial fulfillment \\ of the requirements for the degree of \\ Doctor of Philosophy
}

University of Pittsburgh

2019 


\section{UNIVERSITY OF PITTSBURGH \\ JOSEPH KATZ GRADUATE SCHOOL OF BUSINESS}

This dissertation was presented

by

Pengcheng Zhu

It was defended on

June 21, 2019

and approved by

Dr. David J. Denis, Roger S. Ahlbrandt, Sr. Chair and Professor of Finance, Katz Graduate School of Business

Dr. Diane K. Denis, Katz Alumni Chair and Professor of Finance, Katz Graduate School of Business

Dr. Stephen A. Karolyi, Assistant Professor of Finance and Accounting, Tepper School of Business, Carnegie Mellon University

Dr. Andrew Koch, Associate Professor of Finance, Katz Graduate School of Business

Dr. Kenneth M. Lehn, Samuel A. McCullough Professor of Finance, Katz Graduate School of Business

Dissertation Director: Dr. David J. Denis, Roger S. Ahlbrandt, Sr. Chair and Professor of Finance, Katz Graduate School of Business 
Copyright @ by Pengcheng Zhu 2019 


\section{Do CEOs' Outside Directorships Affect the Performance of Their Own Firms?}

Pengcheng Zhu, PhD

University of Pittsburgh, 2019

The practice of CEOs serving on the board of other public companies has raised concerns from investors and proxy advisory firms about the potential harm to shareholders. In this paper, I analyze the change in performance of CEOs' own firms after their appointment as an outside director at another firm. Using the distance to appointing firms' headquarters as an instrumental variable for directorship appointments, I find that CEOs' own firms exhibit improvements in operating performance following their first appointment and the announcements of such appointments have a positive stock price reaction. Subsequent appointments do not result in performance declines. Performance improvements following the first appointments are stronger in cases where the appointing firm is relatively larger and where the appointing firm operates in vertically related industries. These findings resolve concerns from investors and show that CEOs' own firms can benefit from their outside directorships through CEOs' learning and information sharing. 


\section{Table of Contents}

Preface ................................ ix

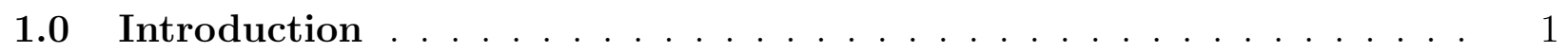

2.0 Literature Review $\ldots \ldots \ldots \ldots \ldots$

$3.0 \quad$ Hypotheses Development and Related Literature . . . . . . . . . . . . 17

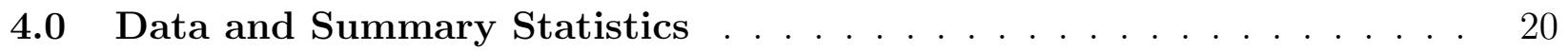

4.1 Sample of CEOs' outside directorship appointments . . . . . . . . . . . 20

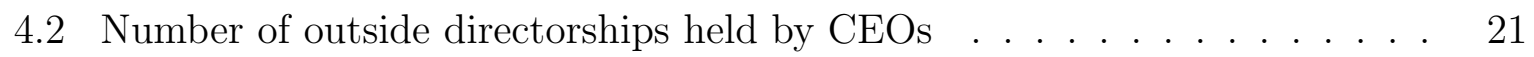

4.3 Characteristics of CEOs' firms and appointing firms $\ldots \ldots \ldots$

4.4 Network centrality of CEOs . . . . . . . . . . . . . . . . . . . 27

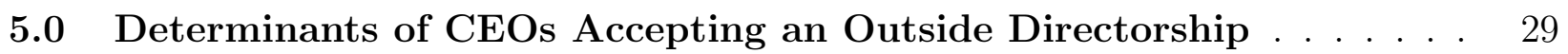

\begin{tabular}{|lll}
\hline 6.0 & Stock Price Reaction to CEOs' Outside Directorship Appointments . & 31
\end{tabular} 7.0 Change in Operating Performance Following CEOs' Outside Directorship

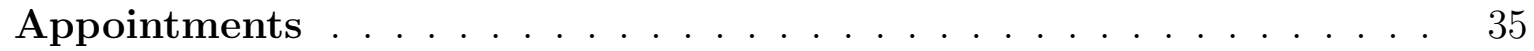

7.1 Change in operating performance, OLS results $\ldots \ldots \ldots \ldots$

7.2 Identification: instrumental variable $\ldots \ldots \ldots \ldots$. . . . . . . . . 38

7.3 Robustness tests $\ldots \ldots \ldots \ldots \ldots$. . . . . . . . . . . . . . . . 42

7.3 .1 Other measures of performance . . . . . . . . . . . . . . 42

7.3 .2 Observation window . . . . . . . . . . . . . . . . . 42

7.3 .3 Serial outside directorship appointments . . . . . . . . . . . 43

7.3 .4 Firms located in big cities $\ldots \ldots \ldots$. . . . . . . . . 43

$8.0 \quad$ Negative Performance Effect of (Multiple) Outside Directorships . . . 44

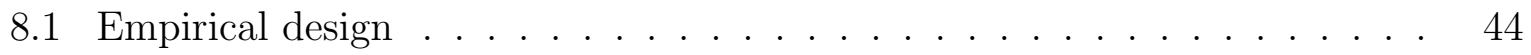

8.2 Agency costs $\ldots \ldots \ldots \ldots \ldots \ldots \ldots \ldots$

8.3 Multiple outside directorships $\ldots \ldots \ldots \ldots$

8.4 Expected number of outside directorships $\ldots \ldots \ldots \ldots$

8.5 Ex-post governance: CEO turnover $\ldots \ldots \ldots \ldots \ldots$ 
8.6 Termination of outside directorships $\ldots \ldots \ldots$. . . . . . . . . . . . . . . . 52

$9.0 \quad$ Beneficial Effect of Outside Directorships . . . . . . . . . . . . . . . . . . 54

9.1 Possible beneficial channels $\ldots \ldots \ldots$. . . . . . . . . . . . . . . . 54

9.2 Further on CEOs' learning . . . . . . . . . . . . . . . . . . . . 56

$9.3 \quad$ Marginal beneficial effect with multiple outside directorships . . . . . . . . 58

9.4 Comovement between CEO's firm and appointing firm . . . . . . . . . . . 59

9.5 Convergence in corporate policies . . . . . . . . . . . . . . . . . . . . . . . 61

10.0 Conclusions . . . . . . . . . . . . . . . . . . . . . . . . . . . . . . 65

Appendix. Definition of variables . . . . . . . . . . . . . . . . . . . 66

Bibliography ............................ 69 


\section{List of Tables}

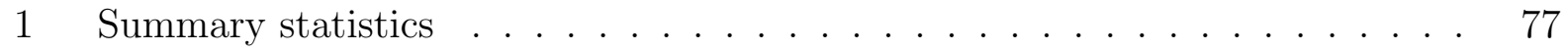

2 Characteristics of CEOs' firms and appointing firms $\ldots \ldots \ldots$. . . . . . 79

3 Determinants of CEOs accepting an outside directorship . . . . . . . . . . . . 81

4 Univariate analyses of CEO firms' announcement effect . . . . . . . . . . . . 82

5 Diff-in-Diff Panel OLS regression of ROA . . . . . . . . . . . . . . . . . 84

$6 \quad$ Diff-in-Diff Panel 2SLS regression of ROA $\ldots \ldots \ldots \ldots \ldots$

$7 \quad$ Robustness tests $\ldots \ldots \ldots \ldots \ldots$. . . . . . . . . . . . . . . . 87

8 Performance effect with agency proxy $\ldots \ldots \ldots \ldots$

$9 \quad$ Performance effect of multiple outside directorships $\ldots \ldots \ldots \ldots$

10 Expected number of outside directorships $\ldots \ldots \ldots$. . . . . . . . . . . 92

11 CEO turnover in CEOs' own firms . . . . . . . . . . . . . . . . . . . . 93

12 Outside directorship turnover in the appointing firms $\ldots \ldots \ldots$. . . . . 94

13 Beneficial effect of CEOs' outside directorships $\ldots \ldots \ldots$. . . . . . . . . 95

14 CEOs' general managerial ability . . . . . . . . . . . . . . . . . . . . . 96

15 CEOs without previous outside director experiences $\ldots \ldots \ldots$. . . . . . 97

16 Marginal beneficial effect with multiple outside directorships . . . . . . . . . 98

17 Change in corporate policies around CEOs' outside directorship appointments 100

A1 Diff-in-Diff Panel OLS regression of ROA in paired sample . . . . . . . . . . 101

A2 Multivariate analyses of CEO firms' announcement effect . . . . . . . . . . 102

A3 Poisson regression of number of CEOs' outside directorships . . . . . . . . . . 105

A4 Regression results for Non-S\&P 1500 firms $\ldots \ldots \ldots$. . . . . . . 106 


\section{List of Figures}

1 Level of ROA around year $\mathrm{t} \ldots \ldots$. . . . . . . . . . . . . . . 75

$2 \quad$ Distribution of distance to appointing firm's headquarters . . . . . . . . . . . 76 


\section{Preface}

I am grateful to my advisor, David Denis, for helpful discussions and suggestions. I acknowledge Diane Denis, Steve Karolyi, Andrew Koch, Kenneth Lehn, Sara Moeller, Frederik Schlingemann, Shawn Thomas, Thomas Scheider, and seminar participants at University of Pittsburgh, 2018 FMA Doctoral Consortium, University of Alabama for helpful comments. Part of this research has been supported by the Pittsburgh Supercomputing Center (PSC) through grant SES180012P. 


\subsection{Introduction}

Although the task of a Chief Executive Officer (CEO) is time-consuming, approximately $30 \%$ of active CEOs at S\&P 1500 firms hold directorships in other firms. Nonetheless, support for the presence of CEOs on other firms' boards is not universal. Some commentators worry that this practice may undermine CEOs' fiduciary duty to shareholders by distracting them from the management of their own firms. For example, a 2017 Wall Street Journal article speculates that CEOs generate extra personal earnings by sitting on outside boards at the expense of shareholders' value in their own firms.1

The two largest proxy advisors, Institutional Shareholder Services (ISS) and Glass Lewis, as well as the investment management firm Blackrock, have expressed similar concerns. ISS ${ }^{2}$, Glass Lewis? ${ }^{3}$, and Blackrock $4^{4}$ in their governance guidelines have made recommendations against CEOs holding more than one or two outside directorships. This view of these institutions has led investors to wonder whether it can be a bad practice for CEOs to sit on outside boards, especially on multiple outside boards at the same time 5 Such sentiments are consistent with a theoretical work by Conyon and Read $(2006)$, who argue that when executives do not have perfectly aligned interests with shareholders they have incentives to hold more outside directorships than the optimal level for shareholders. To study whether this negative view towards CEOs serving on outside boards is supported by empirical evidence, in this paper, I investigate whether CEOs' outside directorships hurt the performance of their own firms.

There are two competing hypotheses concerning the motivation behind CEOs' acceptance of outside directorships and the ultimate effect on the CEOs' own firms. One is the agency hypothesis, which argues that CEOs can pursue private benefits at the expense of shareholders in their own firms. To the extent that CEOs spend time and effort monitoring and advising

\footnotetext{
${ }^{1}$ Who wins when CEOs sit on Multiple Boards? Not investors. By Joann Lublin, Sep 26, 2017. Wall Street Journal (WSJ).

22018 Americas proxy voting guidelines updates, ISS. From the ISS voting guidelines available online, ISS started making the same recommendation since at least 2012.

2017 Proxy season preview, Glass Lewis

${ }^{4}$ Blackrock Proxy voting guidelines for U.S. securities, February 2018.

5 Should CEOs let their C-suite serve on outside boards? By Douglas Chia and Gary Larkin.
} 
other firms, this can impose costs on shareholders if such time could be otherwise spent on managing their own firms. Thus, in the absence of shareholder benefits, CEOs' outside directorships will impose a net cost on their firms' shareholders. Alternatively, the benefit hypothesis argues that CEOs can pursue outside directorships for the benefits of shareholders in their own firms. Though CEOs may have incentives to deviate from maximizing shareholders' value, CEOs' reputation concern and effective corporate governance can pressure them to accept outside directorships only when benefits exceed costs to shareholders. The benefits can be realized through CEOs' learning and information sharing.

Using a sample of 804 CEOs' outside directorship appointments in S\&P 1500 firms between 1999 and 2012, I find that CEOs in larger and older firms with more independent directors on the boards as well as CEOs with shorter tenure and lower beneficial ownership are more likely to accept outside directorships. Given that CEOs with shorter tenure and CEOs in firms with more independent boards are less likely to be entrenched while CEOs with lower beneficial ownership have fewer incentives to maximize shareholder value, it is not clear how the agency problem plays a role in this decision process.

Next, I conduct an event study to examine the stock price reaction to CEOs' outside directorship appointments. I obtain appointment dates from Factiva and appointing firms' proxy statements and 8-K forms. I choose the earliest date as the announcement date. I exclude appointments that are related to major restructuring activities. I also exclude announcements that are within two days of other possible confounding events. When CEOs take their first outside directorships, the average cumulative abnormal returns (CARs) adjusted by value-weighted market index over the $(-1,1)$ day event window are statistically significant and positive. When CEOs take another directorship when they already hold at least one, CARs are not different from zero. I also find that CARs are statistically significant and positive when a CEO is appointed by a firm larger in size. My results overall support the notion that external board service can be beneficial to CEOs' own firms, but also that the costs of additional responsibilities may offset the benefits when CEOs take more than one outside directorship.

Third, I study changes in operating performance measured by return on assets (ROA) around the appointment year in a Difference-in-Difference (DID) regression framework. All 
firms whose CEO does not have a new outside directorship appointment in the entire sample period I consider to be control firms. I use control firms to disentangle the counterfactual outcome of CEOs who do not accept an outside directorship. In the pooled OLS regressions with panel data, I find that compared to the control firms, the average change in ROA is not statistically different from zero from three years before to three years after CEOs' outside directorship appointments.

One challenge to the DID approach and the results of my performance analyses is posed by the endogeneity of CEOs' outside directorship appointments. These appointments and CEOs' acceptance of such appointments can be correlated with firm and CEO characteristics that are also correlated with operating performance. For example, more capable CEOs are more desirable as directors to other firms and are more likely to obtain appointments. At the same time, more capable CEOs are also likely to deliver better performance in their own firms. Omitting CEOs' ability from analysis can introduce a positive bias to estimates of the relationship between CEOs' directorship appointments and the change in performance. On the other hand, CEOs in firms with more agency problems are likely to take more directorships than the desirable number for shareholders. These CEOs may also simultaneously deliver worse performance. Omitting the governance structure from analysis can introduce a negative bias to the estimation results. Thus, it is not clear from economic reasoning in which direction my results may be biased.

To address this concern, I use the instrumental variable (IV) method. I follow the approach of Fahlenbrach, Low, and Stulz (2010) and use the distance to the headquarters of the appointing firm as an instrumental variable for the appointment of a CEO's outside directorship. Since control firms do not have corresponding appointing firms, I pair each firm whose CEO accepts an outside directorship with the control firms in the same two-digit SIC code industry and the same year. The logic of this instrument is that CEOs have high opportunity cost of time and prefer to join boards of nearby firms. Consistently, I find that this instrument is a strongly negative predictor of the probability that a CEO accepts a new appointment. One potential concern of the exclusion restriction requirement is that two firms close to each other can have co-movement in ROA. However, Pirinsky and Wang (2006) show that only stock returns of firms headquartered in the same geographic area tend to 
move together and this co-movement does not apply to economic fundamentals like earnings.

Using a two-stage least squares (2SLS) regression, I find that the change in ROA of CEOs' own firms is not statistically different from zero relative to control firms. This evidence suggests that the effect of CEOs' outside directorships on the performance of CEOs' firms is on average zero.

I find that CEOs' first outside directorships lead to an improvement in performance in their own firms. When CEOs take the second, third, or fourth outside directorships, I do not find a performance decline. My findings here also hold in firms with potentially more agency problems, for example, firms with lower CEOs' ownership, firms without blockholders, and firms with high Entrenchment index. When I take the number of outside directorships CEOs hold as endogenously determined by firm and CEO characteristics, I find that when CEOs are already holding more directorships than the expected number and continue by taking an another, their own firms underperform other firms in the following three years. However, among these firms themselves, I do not find a decline in operating performance.

When CEOs' outside directorships are associated with a decline in the operating performance of their own firms, their directorship terms tend to end more quickly than those of other CEOs. It is difficult to distinguish between CEOs' voluntary resignation, resignation forced by the boards of CEOs' own firms, and forced turnover by the boards of appointing firms. Though it is not clear whether this is due to a CEO's own decision or the result of outside pressure, at least the evidence is suggestive that when CEOs need to spend more time on their own firms, the termination of their secondary responsibility from outside directorships is an option.

Regarding the potential benefits of CEOs' outside directorships, when CEOs are appointed to larger firms or firms that operate in vertically related industries as outside directors, I find that CEOs' own firms perform better in the following three years. This positive performance effect is particularly strong for CEOs with relatively low general managerial ability. This is a reasonable outcome as general managerial knowledge is more easily transferred across firms and industries. The positive performance effect is also stronger for CEOs who do not have any previous experiences as outside directors. My tests of CEOs' general ability and previous outside board experience provide further support for the existence of a learning channel for 
CEOs. Taken together, these results suggest that CEOs' learning and information sharing can be important sources of benefits. There exist anecdotal stories supporting the learning channel. For example, the CEO of Cognizant Technology Solutions Corporation, Francisco D'Souza, joined the board of General Electric in 2013. He stated that "I learned a lot by joining the board of General Electric," and added that "[a] board seat gives you a great vantage point on a company." [6 $\mathrm{my}$ finding concerning information sharing is consistent with that of Dass, Kini, Nanda, Onal, and Wang (2014), namely, that directors from vertically related industries help bridge an information gap.

This paper contributes to two strands of literature. First, this paper is related to studies that examine the appointment of CEOs as outside directors Adams, Hermalin, and Weisbach, 2010). Previous researchers have tried to explain why CEOs sit on the boards of other firms.7 However, as far as I know, none has looked at the effect of CEOs' outside directorships on the performance of CEOs' own firms. Thus, this paper contributes to filling this gap by studying the performance effect in CEOs' own firms. Rosenstein and Wyatt (1994) along with Perry and Peyer (2005) studied the stock price reaction to executives' firms following the announcement of executives' outside directorship appointments. Unlike these two groups of researchers, I take a step further and also investigate the change in performance of CEOs' firms and whether it is caused by CEOs' outside directorships.

Second, this paper is related to studies on busy directors. Fich and Shivdasani (2006) as well as Falato, Kadyrzhanova, and Lel (2014) find that, when outside directors hold too many board positions, their monitoring effectiveness tends to decrease, thereby harming the firms' value. In contrast, Ljungqvist and Raff (2017) show that when directors sit on boards of firms with monitoring synergies, busy directors can be more effective monitors. Since CEOs are different from other directors in terms of their management role and have direct influence on corporate policies, I study whether potentially busier CEOs with outside directorship responsibilities deliver worse performance in their own firms.

\footnotetext{
${ }_{6}^{6}$ Grooming top executives includes outside board experience. March 2016, Wall Street Journal.

${ }^{7}$ For example, Linck, Netter, and Yang (2008) suggest that CEOs with less workload are more likely to serve on outside boards. Perry and Peyer (2005) suggest that CEOs who have poor incentives at their firms to maximize shareholder wealth may be more willing to serve on outside boards.
} 


\subsection{Literature Review}

After Jensen and Meckling (1976) suggested that the agency costs inherent in modern corporations resulting from the separation of control and management, corporate governance has been one of the hottest issues in financial economics. A board of directors is one of the economic institutions that, in theory, can help to solve the agency problems between shareholders and managers. We typically divide directors into two groups, inside directors and outside directors. A director who is a full-time employee of the firm in question is considered an inside director, while a director whose primary employment is not with the firm is deemed to be an outside director. Compared to inside directors, outside directors are less involved in everyday management and have fewer interactions with top executives.

The literature provides evidence consistent with the positive view of outside directors, especially independent outside directors. Multiple studies (Byrd and Hickman, 1992; Cotter, Shivdasani, and Zenner, 1997; Dahya, Dimitrov, and McConnell, 2008; Aggarwal, Erel, Stulz, and Williamson, 2008) indicate that an increase in board independence is associated with higher firm value. However, the difficulty in explaining these results comes from the endogeneity of board structure. Board structure arises endogenously because managers and shareholders choose its form in response to the governance issues they face. More recently, researchers have attempted to establish causality. Nguyen and Nielsen (2010) use sudden deaths of directors as shocks, and find that independent directors provide valuable service to shareholders. Guo and Masulis (2015) use the 2003 NYSE and Nasdaq listing rules change as a natural experiment, and find that greater board independence leads to higher $\mathrm{CEO}$ turnover sensitivity to performance. Knyazeva, Knyazeva, and Masulis (2013) use a supply-based instrumental variable for board independence, and find that board independence has a positive effect on firm value, operating performance, fraction of CEO incentive-based pay, and CEO turnover. Masulis and Zhang (2018) exploit exogenous events that sharply distract independent directors and find that these distraction events lead to declining firm valuation.

However, whether certain independent directors are truly independent from managers and can fully express their opinions when different from those of managers has been in 
doubt. The conventional definition of an independent director is that the director has neither financial nor familial ties to the $\mathrm{CEO}$ or the firm. But an independent director who has other types of connections with the CEO or with the firm may not be truly independent. One example of such is a co-opted director, defined as a director who is appointed by the incumbent CEO. Coles, Daniel, and Naveen (2014) show that firms with more co-opted directors have less effective monitoring, which is reflected in lower CEO turnover-performance sensitivity and higher CEO pay. Another example is a socially connected director. Hwang and Kim 2009) find that firms with more directors who are socially connected to the CEO have lower CEO turnover-performance sensitivity and higher CEO pay. Fracassi and Tate (2012) also find that network ties with the CEO weaken the intensity of board monitoring. Cohen, Frazzini, and Malloy (2010) report another type of directors that are not truly independent - directors who have a prior overly optimistic assessment of the firm as sell side analysts. Lee, Lee, and Nagarajan (2014) find that both social and political connections matter. They find that alignment in political orientation between the CEO and independent directors is associated with lower firm value, lower operating profitability, and increased internal agency conflicts such as a reduced likelihood of dismissing poorly performing CEOs, a lower CEO pay-performance sensitivity, and a greater likelihood of accounting fraud. The evidence from these studies suggests that some outside directors can be independent according to the regulatory definitions but are not truly independent from managers. The heterogeneity of outside directors can obscure the value they add to firms and calls for more careful interpretation of the relationship between board independence and certain firm outcomes.

However, although outside directors have advantages over inside directors in terms of governing managers, the biggest obstacle to their fulfillment of monitoring and advising roles probably comes from information asymmetry between managers and outsiders. Outsiders have less information about firms' investment opportunities and the quality of investment projects. As a result, outside directors may lack the information necessary to evaluate managers' decisions and actions. Several theoretical studies Raheja, 2005; Harris and Raviv, 2006; Adams and Ferreira, 2007) indicate that the effectiveness of outsiders in both monitoring and advising functions depends on their information environment. Duchin, 
Matsusaka, and Ozbas (2010) use the 2003 NYSE and Nasdaq listing rules change as a natural experiment, and find that the effectiveness of independent directors varies with the cost of information acquisition. For firms with low information acquisition costs, greater board independence leads to better performance, while the reverse of this relationship exists for firms with a high cost of information acquisition. The results suggest that a more independent board is not necessarily better for all firms and suggest the potential danger in focusing on certain aspects of governance while ignoring other inherent firm characteristics.

Due to the information advantage held by managers, outside directors are expected to be able to ask the right questions and acquire information useful in fulfilling their roles of monitoring and advisory. As a result, outside directors with a background in specific areas are considered more favorable by shareholders. For example, certain industry experiences enable directors to better analyze information pertinent to firms' operation and financial conditions as well as evaluate the decisions made by managers, thereby providing valuable information to the boards. Wang, Xie, and Zhu (2015) find that the presence of directors with prior experiences in a firm's own industry reduces earnings management and the excess compensation of CEOs, and increases CEO turnover-performance sensitivity. The authors address the endogeneity concern using a geography-based instrumental variable. Dass et al. (2014) examine directors with experiences from a firm's upstream (supplier) or downstream (customer) industries, and find that these directors help bridge the information gap, thereby producing a positive impact on firms' value and performance.

Some studies have focused on outside directors with a specific expertise, for example, financial expertise. Agrawal and Chadha 2005) find that firms with a greater number of outside directors with corporate financial management experience have a lower probability of restating earnings. However, if such directors are also employees of a financial institution, they may inadvertently act as double-edged swords in that they bring benefits to the firms they serve but they also can introduce conflicts of interests between shareholders of their own primary employers and shareholders of the firms they serve as outside directors. Güner, Malmendier, and Tate (2008) find that commercial bankers on boards bring more external financing to the firms and that these firms tend to have good credit but poor investment opportunities. They also find that investment bankers on boards are associated with larger 
bond issues but worse acquisitions. These results suggest that easier access to the capital market through directors as bankers sometimes benefit directors' primary employers rather than the firms doing the borrowing.

When directors represent other parties at the same time, these directors can endanger the interests of shareholders in the firms they serve as outside directors. This does not only apply to bankers. Outside directors representing labor can influence management to take actions favorable to workers rather than shareholders. Faleye, Mehrotra, and Morck (2006) find that labor-controlled publicly-traded firms tend to invest less in long-term assets, take fewer risks, grow more slowly, and exhibit lower labor productivity. Gorton and Schmid (2004) report similar findings for a set of German firms. They find that firms with equal representation of employees and shareholders on the supervisory board trade at a $31 \%$ stock market discount compared with firms where employee representatives fill only one-third of the supervisory board seats. However, Fauver and Fuerst (2006) find that labor representation on boards of German firms is associated with better performance, especially in firms with a greater need for coordination. The benefits from employee representation do not hold for union representatives. The results of these studies suggest that labor representation on boards can affect firm policies, and that the effect on firm value and performance can vary across firms.

Another type of directors comprises ones that are politically connected. Reports from the literature indicate that these directors can be particularly helpful to firms that regularly deal with government or rely on government contracts. Agrawal and Knoeber (2001) find that firms relying more on governmental decisions are more likely to appoint directors with backgrounds in politics and law. Goldman, Rocholl, and So (2013) consider the nature of political connections in greater detail, and find that firms in the US with boards connected to the winning party experience a significant increase in procurement contracts after the 1994 election.

Directors of United States (US)-based firms are not themselves necessarily solely domestic but can also reside and work in countries outside the US. Masulis, Wang, and Xie (2012) document that about $13 \%$ of S\&P 1500 corporations have foreign independent directors, defined as independent directors domiciled in foreign countries. These directors can be US citizens or foreign nationals. The authors find that these directors help firms make 
better cross-border acquisitions, but reduce board effectiveness in monitoring and disciplining CEOs. The net effect on firm performance is negative, especially when the firm's operation in the outside director's home region becomes less important. Estélyi and Nisar (2016) focus on foreign nationals on boards without regard for where these individuals reside. The authors find that directors with foreign nationality contribute to board diversity and that this diversity is positively associated with firms' international market operations and operating performance. Iliev and Roth (2018) focus on directors' foreign board experiences, and find that companies converge to the governance characteristics and board practices of foreign firms through these directors. This learning channel is stronger for firms domiciled in less-developed governance markets, suggesting a spillover of better governance practices.

Directors with management skills who have experience in running other firms are in high demand from public firms. CEOs at other firms understand the issues facing top management and have experiences and skills that can be essential to monitoring and advising. Although the latter may not be shared by other professional directors, CEO directors' experiences can be valuable for advising the CEO at the appointing firm, especially if the CEO directors previously have dealt with similar situations. Small firms with a lot of growth opportunities tend to have greater advisory needs and would benefit from having CEO directors on their boards. CEO directors also have a unique authority in that they can deal with the CEO of the appointing firm as peers, and stand up to the CEO in a way that typical outside directors cannot (Fahlenbrach et al., 2010). With all these advantages in mind, however, CEO directors are not always desirable candidates for outside directors. CEOs are already busy managing their own firms, thus it is questionable whether they also have enough time to devote to disciplining the $\mathrm{CEO}$ and providing valuable advice to the appointing firm. In addition, if two CEOs simultaneously serve on the board of each other's firm, this interlock practice can introduce mutual "back-scratching" so that two CEOs make each other's life easier and reduce the disciplining efforts of both firms.

The empirical evidence concerning whether CEO directors add value to the appointing firms is mixed. Fich (2005) reports that investors react more positively to CEO directors than other outside directors, and finds increases in operating performance after the appointments of $\mathrm{CEO}$ directors. The author suggests that CEOs are sought as outside directors to enhance 
firm value. The caveat in the study is that the author does not address the endogeneity concern of CEOs' outside directorships. In a more recent study, Fahlenbrach et al. (2010) use a geography-based instrumental variable and find no evidence that CEOs on boards add value and influence corporate policies, at least relative to other outside directors. The authors suggest that CEOs may strategically choose their board seats in firms that require less time and effort to monitor and advise or that CEOs are too busy with their primary firm to have a substantial impact on the boards they sit on. Kang, Kim, and Lu (2017) find that outside directors with CEO experiences in the same industry are particularly helpful in enhancing value-added growth by guiding managers towards higher value-added R\&D investment and higher quality innovations.

Unlike the previous mixed results, more consensus exists concerning the negative aspects of the CEO interlock practice. Hallock (1997) document that about $8 \%$ of CEOs are reciprocally interlocked with another CEO and roughly $20 \%$ of firms have at least one current or retired employee sitting on the board of another firm. Interlocked CEOs earn significantly higher compensation. Fich and White (2005) explore why CEOs sit on each other's boards. They find that CEOs' bargaining power, which is measured by longer tenure, a good performance record, and a seat on the board's nominating committee, is positively associated with interlocks. The authors argue that their findings are consistent with the view that a reciprocal CEO interlock is more likely a means used to enhance a CEO's private interests and is less likely a corporate governance feature for advancing the interests of shareholders. Fahlenbrach et al. (2010) find that when CEOs sit on each other's boards, there is a decline in operating performance following the appointment of an interlocked CEO director. Bizjak, Lemmon, and Whitby (2009) extend the analyses to interlocked boards instead of interlocked CEO directors. They find that board interlocks increase the likelihood of "option backdating", a controversial practice that serves to increase top management's pay by ex post adjusting the date on which options are dated. This finding provides further evidence that interlocks benefit management, possibly at the expense of shareholders.

With respect to the supply side of CEO directors, researchers have examined why both CEOs and their own firms want CEOs to devote time and effort to other firms. Board service is time consuming, so CEOs who have more flexibility in their use of time may be 
more likely to take outside directorships. Vancil (1987) finds that CEOs are more likely to serve on outside boards when close to retirement and their own firms are likely to promote one of the inside management members to the CEO position. The author suggests the reason for this action is the expectation that the CEO may delegate some authority to the future CEO and thus freeing more time for the CEO to serve as an outside director at another firm. Booth and Deli (1996) find that CEOs at firms with fewer growth opportunities and CEOs not taking a Chairman role hold more outside directorships. They also find that an outside directorship can be a means of bonding with suppliers and customers when a CEO is also a director on the supplier's (buyer's) board.

In addition to motivations that are value increasing to shareholders, CEOs may pursue board seats for their own benefit. Perry and Peyer (2005) find that CEOs who have less incentive to maximize shareholder value at their primary firms are more willing to serve on outside boards. CEOs who serve as outside directors may acquire personal benefits in the form of monetary as well as non-monetary compensation. Yermack (2004) finds that a one standard deviation increase in firm value results in a change of a director's expected wealth by about $\$ 285,000$. Though financial incentives for outside directors are much smaller than those offered to top managers, the incentives appear nontrivial to directors, especially for those who serve on multiple boards. Adams and Ferreira (2008) find that directors are less likely to miss board meetings when board meeting fees are higher, suggesting that compensation plays a role in some directors' participation.

Along with monetary compensation, experience as an outside director can increase a CEO's reputation. Fich and White (2005) find that well-performing CEOs are more likely to obtain outside directorships, and that serving as an outside director further increase a CEO's chance of obtaining a director position in the future. Numerous studies indicate that CEOs value their reputation and are more likely to join boards that will provide them with information and better prospects. Linck et al. (2008) find that the willingness of CEOs to serve as directors is negatively related to the workload and the risk of having a bad performance in the position. Masulis and Mobbs (2014) find that directors put more effort into firms with more prestige by increasing their board attendance rate and that directors are less willing to relinquish their relatively more prestigious directorships. The authors use 
firm size to measure prestige. Fahlenbrach, Low, and Stulz (2017) find that outside directors tend to leave boards in anticipation of negative stock and operating performance in order to protect their reputation. Reports from the literature suggest that monetary compensation may play a role in CEOs' decisions, but that reputation considerations and career concerns may be more important determinants of CEOs' willingness to accept outside directorships.

While there has been an extensive discussion in the literature concerning CEOs' motivation for accepting outside directorships, it is surprising that there is little empirical evidence on the effect of CEOs' outside directorships on their own firms. Rosenstein and Wyatt (1994) use a sample of 124 announcements in which an officer of one public firm joins the board of another firm and look at the abnormal returns following these announcements. They find negative average abnormal returns for nonfinancial sending firms and positive average abnormal returns for financial sending firms. The authors attribute the negative abnormal returns in nonfinancial sending firms to the distractions posed for CEOs by the added duties and attribute the positive abnormal returns in financial sending firms to better networking by the CEOs. However, the authors do not provide evidence supporting their hypotheses. Perry and Peyer 2005) use a sample of 349 announcements in the period from 1994 to 1996 in which an executive officer of one public firm joins the board of another. They find that, when CEOs already have at least two outside directorships, the average abnormal stock returns are negative in sending firms with higher agency costs, as measured by CEOs' beneficial ownership and board independence ratio.

While both of these studies include CEO executives as well as non-CEO executives, the finance literature contains more evidence linking firm value and operating performance to CEOs (Bertrand and Schoar, 2003). There is not much evidence suggesting that non-CEO executives have a direct effect on firm value and operating performance. Also, both studies consisted of examinations of the stock price reaction to CEOs' firms at the announcement of outside directorship appointments. It is possible that an announcement of outside directorship signals a CEO's talent, thereby enabling more investors to appreciate this CEO's value. Thus, the positive stock price reaction from an event study does not necessarily reflect any material effect on the performance of the primary firms of the CEOs under study. On the other hand, negative stock price reactions may reflect extant agency problems in the CEOs' 
own firms and do not lead to any further decline in performance. Thus, it is also important to investigate the changes in the performance of sending firms. In any event, if CEOs' outside directorships have a material effect on performance in subsequent years, additional evidence is needed to shed light on the channels through which this performance effect works.

Conyon and Read (2006) offer a theoretical explanation to the effect that serving on the boards of other firms helps to build CEOs' human capital. At the same time, however, with the existence of the principal-agent problem between managers and shareholders, CEOs have incentives to hold more directorships than the optimal level from shareholders' perspective to gain additional income and prestige. CEOs' outside directorships can benefit their own firms, but the benefits may be offset by costs from holding too many outside directorships. Ultimately, it is an empirical question whether CEOs' outside directorships benefit or hurt their own firms.

There are anecdotal stories suggesting benefits from outside directorships may enhance CEOs' human capital. For example, the CEO of Cognizant Technology Solutions Corporation, Francisco D'Souza, joined the board of General Electric Co. in 2013. He stated that "I learned a lot by joining the board of General Electric" and added that "[a] board seat gives you a great vantage point on a company."1 However, there is a lack of empirical evidence from a large sample showing that CEOs have gained human capital from outside directorships which in turn adds value to their own firms.

Empirical studies indicate that when a director serves on boards of firms that are related, information sharing and transfer of experiences can benefit these firms. The same logic applies to the context of CEOs' firms and appointing firms. Directorship can act as a channel through which information and skills are transferred between firms. Dass et al. (2014) show that directors from companies in upstream or downstream industries help bridge an information gap. In particular, these directors can help overcome information challenges such as anticipating industry conditions, which is especially important for firms in innovative industries facing unpredictable supply and demand. Ljungqvist and Raff (2017) find that monitoring synergies exist when directors sit on the boards of multiple firms in related industries. However, not all studies indicate a positive influence resulting from directors

\footnotetext{
${ }^{1}$ Grooming top executives includes outside board experience. March 2016, Wall Street Journal.
} 
from vertically related industries. Ellis, Fee, and Thomas (2018) find that the presence of industry expert directors on boards lead to increased segment investment yet the profitability of these segments is lower, which is more consistent with the view that experienced directors play favorites rather than act as dispassionate advisors.

Networking may be another channel by which CEOs' firms benefit from CEOs' outside directorships. A CEO's network is likely to expand after outside directorship appointments through connection with directors in the appointing firm. The literature indicates that personal connections provide an effective channel for private information. Cohen, Frazzini, and Malloy (2008) find that portfolio managers place larger bets on connected firms and perform significantly better on these holdings relative to their nonconnected holdings. Cohen et al. (2010) find that sell-side analysts perform better if they share an alma mater with the key executives of covered firms. Larcker, So, and Wang (2013) show that firms with more connected board members earn superior risk-adjusted stock returns that can be attributed to greater information access. In the context of executives, Fracassi (2016) finds that managers are influenced by their social peers when making corporate policy decisions and that managers sharing more connections tend to adopt similar policies.

However, executives' network connections are not always beneficial to shareholders. Personal ties can interfere with effective corporate governance and director monitoring by weakening directors' independent judgment. Hwang and Kim (2009) find that CEOs with personal connections to board members have higher compensation, lower pay-performance sensitivity, and lower turnover-performance sensitivity. Fracassi and Tate (2012) show that CEO-director connections weaken board monitoring and destroy corporate value. El-Khatib, Fogel, and Jandik (2015) find that CEOs who are more central in their social network tend to conduct more M\&A deals with value losses compared to less central CEOs.

The negative view of CEOs' outside board service shares the same rationale that busy directors deliver worse performance due to overcommitment. Earlier studies have mixed results on whether busy directors are value-destroying (e.g., Core, Holthausen, and Larcker, 1999; Ferris, Jagannathan, and Pritchard, 2003; Fich and Shivdasani, 2006; Field, Lowry, and Mkrtchyan, 2013), while recent studies have more evidence supporting the value-destroying argument. Falato et al. (2014) use the sudden death of a board member as an exogenous 
shock that reduces outside directors' attention to their other board committees, and find that directors' busyness is detrimental to board monitoring quality and shareholder value at other firms. Hauser (2018) studies directors who lose a directorship after a merger, which makes them less busy, and finds better performance from less distracted directors. The most related paper in the context of executives is Perry and Peyer (2005), who find that announcement returns are negative when executives take multiple directorships simultaneously and executives' firms have more severe agency problems. 


\subsection{Hypotheses Development and Related Literature}

Whether a CEO accepts a board position offered at another firm is a decision made jointly by the CEO and the board of directors at her own firm. A CEO does not need formal shareholder approval to accept outside directorships, but the CEO typically communicates with the board of her own firm and receives informal approval before joining outside boards 1 Whether a board allows the CEO to take an outside directorship presumably depends on the board's perception of costs and benefits to the shareholders. Meanwhile, the CEO weighs her private costs and benefits when making this decision. This process, therefore, has the potential to generate conflicts of interest between the CEO and shareholders.

When CEOs' outside directorships are mainly driven by CEOs' private benefits instead of the interests of shareholders, shareholders can be worse off. In contrast, when the benefits to shareholders exceed the costs borne by shareholders, CEOs' outside directorships would benefit their own firms.

CEOs' private benefits come in both pecuniary and non-pecuniary forms. Pecuniary benefits are compensation packages from the appointing firms. Though several studies (Yermack, 2004; Adams and Ferreira, 2008) point out that monetary compensation plays only a small role in attracting CEOs to serve as outside directors, this perquisite can be desirable, especially for CEOs whose pay is not in the top tier. In terms of non-pecuniary benefits, external directorships signal CEOs' talent and ability as well as improve their reputation in the director labor market, thus increasing their chances to obtain director positions in the future (Yermack, 2004; Fich, 2005; Adams and Ferreira, 2008).

The time and effort that CEOs spend on monitoring and advising other firms can impose costs on their own firms. It is important to note that CEOs bear only a fraction of the costs since they are less than $100 \%$ owners. Boards of directors in CEOs' own firms are supposed to prevent CEOs from simply pursuing private benefits and endangering shareholders' wealth, but directors do not always act in the interest of shareholders due to incentives not perfectly aligned with those of shareholders. When there is no effective internal or external governance

\footnotetext{
${ }^{1}$ Questions to Ask When Your Director or Executive Officer Wants to Join Another Board. March 2012.
} 
to curb CEOs' behavior, CEOs are more likely to seek external directorships regardless of the cost to shareholders. Both CEOs' incentives and corporate governance play a role in CEOs' decisions to take external directorships.

Thus, in the absence of other shareholder benefits from CEOs serving as outside directors at other firms, CEOs' outside directorships will impose a net cost on shareholders. Conyon and Read (2006) show with a model that executives with interests less than perfectly aligned with those of shareholders are likely to spend more time on external directorships than is optimal for their own firms.

The potential harm to shareholders from CEOs' extra responsibilities is analogous to the possible reduction in monitoring effectiveness from busy directors, which has been documented in the literature. Several studies of busy boards (Fich and Shivdasani, 2006, Falato et al., 2014) suggest that when directors hold too many board positions, it can be detrimental to their monitoring effectiveness and eventually to the firms' value. CEOs' additional responsibilities as outside directors can be a cause for concern, especially when CEOs hold multiple outside directorships at the same time. Loderer and Peyer (2002) and Perry and Peyer (2005) study the announcement effect of CEOs' outside director appointments and provide some evidence consistent with this argument.

In sum, when the agency problem is the main issue, CEOs with stronger incentives to seek private benefits and CEOs working in firms with less effective governance are more likely to accept outside director positions. Under this agency hypothesis, I expect that the immediate stock price reaction to the announcements of CEOs' outside director appointments to be negative and that the long-term operating performance of CEOs' own firms to decline.

Alternatively, CEOs' outside directorships may be driven by motivations that benefit shareholders. Under this benefit hypothesis, I expect that the immediate stock price reaction to the announcements of CEOs' outside directorship appointments to be positive and the long-term operating performance of CEOs' own firms to improve.

CEOs' outside directorships can benefit their own firms in at least four ways. First, CEOs' outside directorships can enhance their human capital and management skills (Perry and Peyer, 2005), which in turn benefit their own firms. The benefits may be greater when CEOs join the boards of larger and more prestigious firms. Second, the appointment of 
a CEO to another firm's board can facilitate information sharing between these two firms. Shared information is potentially more important if two firms are similar or related industries. Dass et al. (2014) find that directors from companies in upstream or downstream industries help bridge an information gap. Ljungqvist and Raff (2017) find that monitoring synergies exist when directors sit on the boards of multiple firms in related industries. Third, CEOs can benefit from new connections with directors in the appointing firms. Some anecdotal evidence suggests that CEOs get the most from what directors in other firms can provide on certain topics rather than simply observing how other firms conduct their business.2 In addition to direct connections, CEOs may form new indirect connections through directors in the appointing firms. Well-connected CEOs usually have better and easier access to valuable information and more resources with which to achieve their goals (El-Khatib et al., 2015). Fourth, CEOs' firms can sign new contracts with the appointing firms. CEOs' directorships help reduce coordination costs and contractual frictions, which facilitate the contracting process and make the appointing firms more likely to become new suppliers or customers (Booth and Deli, 1996). This new business relationship can benefit CEOs' firms by increasing growth opportunities as well as boosting sales and operating performance. These channels are not mutually exclusive and may overlap each other. For example, a seat on the board of a larger firm not only facilitates a CEO's learning but also enables information sharing and expansion of the CEO's network.

Though CEOs may have incentives to deviate from maximizing shareholders' value, their reputation concern and effective corporate governance can pressure CEOs to accept outside directorships only when the benefits to shareholders exceed the costs to shareholders. More independent boards and more effective monitoring from investors are usually associated with less entrenched CEOs. In addition, CEOs' reputation depends on the performance of their own firms. Brickley, Linck, and Coles (1999) show that the likelihood a retired CEO serves on her own board and/or an outside board is positively related to her performance as a CEO. As a result, CEOs may not want to sacrifice their own firms' performance to seek private benefits from outside directorships because the cost can be too high.

\footnotetext{
$\sqrt[2]{\text { Fewer CEOs are serving on outside boards. By Marc Hogan, G100 Companies. }}$
} 


\subsection{Data and Summary Statistics}

\subsection{Sample of CEOs' outside directorship appointments}

I obtain data on directors from the ISS (formerly RiskMetrics) database for the years 1999 to 2012. The sample begins in 1999 because the records in ISS before 1999 are incomplete. The sample ends in 2012 because the analyses in this paper require financial variables at least three years following directorship appointments. In other words, my data on financial variables ends in 2015. The ISS database contains yearly individual directors' information for S\&P 1500 firms. I include both independent directors and linked directors (often called gray directors), directors who are affiliated with the firms they serve.

Data on CEOs is from the BoardEx database. BoardEx includes information about senior management members, directors, and other related employees. I identify individuals who are labeled as CEOs based on the description of their roles in the database. To determine which CEOs are also outside directors in other firms, I match the CEO data and the director data by individual's name, age, and primary employer's name. ISS discloses most directors' primary employer. For outside directors who have multiple primary employer matches in the same year, I manually choose the correct employer by searching information in the proxy statements of appointing firms. For each CEO, I require the directorship appointment year to be during this CEO's tenure.

I require CEOs' firms to have data in Compustat and CRSP. In addition, I require firm-year observations to have data on key variables - firm size, market-to-book asset ratio, and return on assets. I only include public firms whose headquarters are located within the US. I add this requirement because later in the paper I will use firms' headquarters locations to calculate the distance between firms, while non-U.S. firms are irrelevant for this calculation. The data ona CEO's total compensation and beneficial ownership is from S\&P's ExecuComp database.

Since appointing firms from the ISS database are S\&P 1500 firms, and the ExecuComp 
database only covers S\&P 1500 firms, I require CEOs' firms to be S\&P 1500 firms as well $\bigsqcup^{1}$ To identify S\&P 1500 firms, I use the Index Constituents dataset in Compustat. Nearly 80\% of CEOs' firms are S\&P 1500 firms.

The final sample of CEO directors is the overlap of BoardEx, ISS, Compustat, and CRSP databases. This sample covers S\&P 1500 firms whose CEO becomes an outside director in another S\&P 1500 firm between 1999 and 2012. The sample contains 804 CEOs' outside directorship appointments for 641 unique CEOs. Out of 641 CEOs, 510 (79.6\%) have one directorship appointment during the sample period, 109 (17\%) have two appointments, $15(2.3 \%)$ have three appointments, $5(0.8 \%)$ have four appointments, one CEO has five appointments, and one CEO has six appointments.

\subsection{Number of outside directorships held by CEOs}

In this section, I document summary statistics related to the number of CEOs' outside directorships. The ISS database has a variable named outside_public_boards that measures the number of public boards a director sits on every year. However, this variable is problematic for four reasons. First, for some firms this variable includes cases of a CEOs sitting on her home board, while for some this variable only includes outside boards. This issue can happen for the same CEO across different years within the same firm. Second, this variable counts the number of directorships a CEO holds at the proxy statement filing date of CEO's own firm. If a CEO's outside directorship appointment occurs before the filing date during that fiscal year, then this variable includes the new appointment. Otherwise, this variable does not include the new appointment. Third, when a CEO holds multiple outside directorships in a fiscal year, this variable can have different values in the same year. This problem arises due to different proxy statement filing dates and also because the ISS can have wrong entries for a CEO's primary employer (CEO's own firm). Fourth, this variable is missing for some CEOs.

\footnotetext{
${ }^{1}$ In robustness tests, I find that excluding non-S\&P 1500 firms does not affect the main results. In fact, no results show up with statistical significance among non-S\&P 1500 firms as shown in Appendix Table A4.
} 
Due to these issues, I manually collect the number of outside directorships a CEO already holds right before a new appointment. For each appointment, I read the proxy statement of CEO's own firm and count how many boards of public firms a CEO already sits on. To determine whether a firm is public or not, I use the information on a firm's website, Bloomberg, and the Securities and Exchange Commission (SEC)'s Electronic Data Gathering, Analysis, and Retrieval system (EDGAR) website. I then cross check with proxy statements of the appointing firm and other firms in which the CEO holds an outside directorship. It is common for CEOs to accept a new outside directorship right after or not long before an existing directorship ends. If this CEO's existing outside directorships end before the new appointment or end after the new appointment but in the same fiscal year and there is an indication that this CEO plans to resign from the existing one(s), then I do not include these existing directorships. I make this adjustment to focus on how many outside directorship commitments a CEO has after a new appointment.

I report the frequency distribution of this number in Table 1 Panel A. For $48 \%$ of CEOs, when they accept a new appointment, they do not have other continuing outside directorship commitments in hand. $32 \%$ of CEOs already have one outside directorship before a new appointment and decide to hold two at the same time. $15 \%$ of CEOs already have two, and $5 \%$ of CEOs already have at least three. The data suggests that it is common for CEOs to hold more than one or two outside directorships at the same time.

\section{[Insert Table 1 here]}

Panel B displays the number of outside directorship appointments by year. From 1999 to 2012, out of all firms' outside directorship appointments, about 5\% are held by directors who are also CEOs in other firms. The percentage does not vary much over time. This percentage is comparable to the number (around 5\%) reported in Fahlenbrach et al. (2010) and lower than the numbers reported in Booth and Deli (1996) as well as Fich (2005) that focus on larger firms.

Since CEOs' outside directorships beginning before 1999 are not included in the sample, in Panel C I report the number of firms whose CEO holds at least one outside directorship 
between 1999 and 2012 regardless of the appointment year. ISS has a complete coverage of public firms in which a CEO at another firm serves as an outside director. For each CEO every year, I use the number of public firms, in which the CEO serves as an outside director, as the number of outside directorships a CEO holds. On average about $28 \%$ of S\&P 1500 firms have their CEOs sitting on at least one outside board. The percentage numbers seem a little low compared to the numbers sometimes reported in the press. For example, the Spencer Stuart 2012 board index document ${ }^{2}$ reports that about $48 \%$ of CEOs in S\&P 500 firms hold at least one outside directorship in other firms. To identify S\&P 500 firms, I find firms that constitute the S\&P 500 index every year from the Index Constituents database in Compustat. I report the statistics in the last three columns in Panel C. On average, about $43 \%$ of CEOs in S\&P 500 firms sit on outside board(s). This suggests that CEOs in larger firms are much more likely to hold outside directorships than CEOs in smaller firms.

\subsection{Characteristics of CEOs' firms and appointing firms}

Table 2 displays the summary statistics of firms whose CEO accepts a new outside directorship. I compare firms whose CEO accepts a new outside directorship appointment in a fiscal year to firms whose CEO does not.

[Insert Table 2 here]

As shown in Panel A, firms whose CEO accepts a new outside directorship appointment are larger and older. These firms have better operating performance. This can be explained from both supply and demand sides. On the supply side, investors are less likely to challenge when CEOs have done a good job. On the demand side, firms are more likely to hire CEO directors with good track records. CEOs accepting new outside directorships tend to have shorter tenure, higher total compensation, more equity-based compensation, and lower

\footnotetext{
${ }_{2}^{2}$ Spencer Stuart 2012 board index report.
} 
beneficial ownership than CEOs that do not. In Section 5, using a multivariate regression, I will examine how these characteristics are associated with CEOs' acceptance of outside directorships.

Panel B displays the relation between CEOs' own firms and the appointing firms.

In the sample, over $50 \%$ of CEOs are appointed by larger firms (as measured by market value and market share). This is consistent with the notion that CEOs usually join boards of larger firms to acquire a better reputation, which is also reported in Fahlenbrach et al. (2010). A firm's market value is the stock price at the end of a fiscal year multiplied by number of common shares outstanding. A firm's market share is the percentage of its sales in the same two-digit Standard Industrial Classification code (SIC2) industry.

Under Section 8 of the Clayton Antitrust Act, directors cannot serve on boards of competing firms. In $14 \%$ of CEOs' outside directorship appointments, CEO's own firm and the appointing firm are in the same SIC2 industry. When I use four-digit SIC code or industry classifications defined by Hoberg and Phillips 2010) and Hoberg and Phillips (2016), which analyze product descriptions in 10-K forms, in less than $10 \%$ of appointments, CEO's own firm and the appointing firm are in the same industry. This does not mean that some CEOs have served in competing firms. For example, in February 2012, Adobe System's CEO - Bruce Chizen - was appointed to join the board of Synopsys, Inc. Both firms are in the industry sector categorized as prepackaged software (SIC code: 7372) and are grouped into the same industry based on Hoberg-Phillips classifications. However, Adobe Systems and Synopsys operate in different niche markets and are not considered direct competitors along their main product lines. However, due to the potential for industry misclassifications resulting from use of the SIC code pointed out by Hoberg and Phillips (2016), henceforth, I will define two firms in the same industry based on Hoberg-Phillips classifications.

In about $10 \%$ of new appointments, CEO's own firm and the appointing firm are in vertically related industries based on the Bureau of Economic Analysis (BEA) Input-Output tables. I follow the procedure outlined by Becker and Thomas (2011) together with that of Ahern and Harford (2014) to calculate the customer-supplier trade percentage between two industries. When two firms operate in two industries that have a customer-supplier relationship and either customer percentage or supplier percentage exceeds $1 \%$, I define 
these two firms as vertically related. I find that, in vertically related cases, CEOs' firms cluster in computer and electronic equipment industry as well as business service industry (results not tabulated).

In addition to industry relationships, Hameed, Morck, Shen, and Yeung (2015) and Ljungqvist and Raff (2017) suggest that two firms are informationally related if one firm's earnings can explain the other firm's earnings after controlling for market and industry earnings. Informationally related firms tend to have co-movement in fundamentals. Following Hameed et al. (2015), for each CEO firm-appointing firm pair, I first regress the quarterly return of assets (ROA) for the CEO's firm over a five-year window on market ROA (the value-weighted average ROA of all firms, excluding the CEO's firm and the appointing firm) and industry ROA (the value-weighted average ROA of all firms in the same Fama-French 48 industry, again excluding the CEO's firm and the appointing firm), and obtain $R_{1}^{2}$. I require at least 12 non-missing quarterly observations over the five-year window. Next, I add the ROA of the appointing firm to the regression and obtain $R_{2}^{2}$. The contribution of this latter ROA to the explanatory power is defined as $\left(R_{2}^{2}-R_{1}^{2}\right) /\left(1-R_{1}^{2}\right)$. This number is the information correlation between two firms. In the sample, about $61 \%$ of firm pairs have sufficient data to calculate this information correlation. I define two firms informationally related if their information correlation is above the sample median. When I use this measure, about $30 \%$ of firm pairs are informationally related.

About $12 \%$ of the CEO's own firm and the appointing firm have business transactions in at least one year within three years around appointment. For a director who is also the CEO in another firm, the appointing firm usually discloses in the proxy statements if there is a business relationship with the primary employer of this director, especially after 2002 when the Sarbanes-Oxley Act was passed and NYSE and Nasdaq exchanges issued new listing rules about disclosure of directors' independence (Chhaochharia and Grinstein, 2007). On the SEC's EDGAR website, I search the appointing firm's proxy statements between three years before and three years after a CEO's appointment to identify business transactions between the CEO's firm and the appointing firm. The most common business transaction comes from a customer-supplier relationship, while other forms, such as a joint venture or a purchase alliance, are rare. 
When a business transaction exists, the transaction amount is always very small, which is often described as insignificant in the proxy statements. For directors who are identified as linked in ISS, they are mostly identified as independent directors by the appointing firms based on NYSE and Nasdaq rules. This is due to the fact that ISS has a more restrictive definition of directors' independence than the NYSE and Nasdaq Chhaochharia and Grinstein, 2007). A director who has a business relation with the firm is defined as independent based on NYSE and Nasdaq rules as long as the business relation is insignificant. In contrast, ISS would define a director like this as linked.

In my sample, only $2 \%$ of the CEOs' firms already have business transactions with the appointing firms before CEOs' appointments. About $11 \%$ of the CEOs' own firms start a new business relationship with the appointing firms after appointments are made or in the same year.

Firm disclosures about transactions have a different level of detail. Some firms only describe the business relationship as insignificant, while some firms have dollar amount of transactions. For this reason, I do not quantify the business relation to avoid self-reporting bias. For example, Bruce Claflin, the then CEO of 3Com Corporation, was appointed to the board of Advanced Micro Devices (AMD) in 2003. AMD disclosed that "Although the Company received payment from 3Com Corporation for product purchases during 3Com's fiscal year 2002 and 2003, the Board has concluded that the business relationship of Mr. Claflin, as Chief Executive Officer of 3Com, with the Company is well below the thresholds in the NYSE independence rules, is otherwise immaterial and does not interfere with Mr. Claflin's exercise of independent judgment in his service on the Audit Committee." As another example, Michael Splinter, the then CEO of Applied Materials, was appointed to the board of NASDAQ OMX in March 2008. These two firms started a new business relationship in 2009. In fiscal year 2009 and 2010, NASDAQ OMX disclosed that "Applied Materials paid NASDAQ OMX approximately $\$ 0.1$ million in the ordinary course of business." 


\subsection{Network centrality of CEOs}

After a new outside directorship appointment, a CEO will likely forge new connections to directors in the appointing firm and new indirect connections through these directors. To measure changes in a CEO's network around new appointments, I use network centrality measures.

First, I need to construct a network that connects all directors. The BoardEx database has biographical information on directors and top executives, including past and current employment, education, and other activities. Following Fracassi (2016), I use individuals' biographical information to construct pairwise network connections between each pair of individuals in the database for each year. Employment connections capture overlap of employment in organizations including public firm, private firm, nonprofit organization, government sector, and university. Education connections require that two individuals attended the same school and graduated within one year of each other. Connections developed from other activities comprise an overlap of participation in clubs, nonprofit organization, associations, foundations, and institutions. As some organizations are large and members probably don't know each other, I require that an individual is not merely a member and has an active role in the organization. Common active roles are director, President, Chairman, Trustee, and committee member. For any two individuals, as long as they have one connection, they are defined as connected. More connections between two individuals do not necessarily mean stronger connections, so I merely define this binary relationship and do not add weight to connections.

Network centrality is a collection of measures that describe an individual's position and importance in a social network. Two centrality measures are commonly used in the network analyses and finance literature (El-Khatib et al., 2015; Fracassi, 2016):

(1) Degree: The number of direct connections (or first-degree connections) an individual has scaled by the total number of individuals in the network. It measures the relative size of an individual's direct network.

(2) Eigenvector: A relative score assigned to an individual based on the concept that more connected individuals contribute more to the network. It measures the importance and 
influence of an individual in the network and considers how well an individual is connected to other highly connected individuals.

For both measures, a higher value means that an individual is more central in a network and is more exposed to word-of-mouth information as well as knowledge of available resources.

Nguyen (2012) finds that a CEO's social activity connections with directors in the firm are associated with weaker corporate governance. Fracassi (2016) finds that only employment and education connections between the directors/CEOs of two firms are associated with similarity in corporate policies. As it is not clear which type of CEOs' network matters more in the context of this paper, I therefore use all types of social network including employment connections, education connections, and other activities connections in BoardEx ${ }^{3}$ Once a connection is formed, it continues to exist until one individual passes away. Thus, the network is monotonically increasing over time. In 2012, the network includes over 84 million employment connections, 45 million education connections, and 5 million other activities connections.

I compute centrality measures for each year from 1998 to 2013 to calculate the change in each CEO director's centrality. Table 2 Panel $\mathrm{C}$ shows that after new appointments, CEO directors on average become more central in their network. CEOs' degree and eigenvector have a positive change in both mean and median values. Both mean and median values of changes are statistically significant at the $1 \%$ level. The positive changes indicate that outside directorships help CEOs build more connections.

\footnotetext{
${ }^{3}$ In robustness tests, I find that using more restrictive connections, for example, only employment connections, only employment connections in public firms, only education connections, and only other activities connections, does not change the results qualitatively. For employment connections, the results do not change qualitatively either if I require that the overlap of employment did not end more than ten years ago.
} 


\subsection{Determinants of CEOs Accepting an Outside Directorship}

I use logistic regressions to study characteristics of both the firm and the CEO which are correlated with CEOs' acceptance of outside directorship appointments. In the logistic regressions, the dependent variable is a dummy variable equal to one for 804 firm-year observations in which a $\mathrm{CEO}$ accepts a new outside directorship in that year, and equal to zero for other control firm-year observations.

Estimating non-linear models with fixed effects introduces the incidental parameter problem. Consequently, maximum likelihood estimators are generally inconsistent. To avoid this issue, I choose the conditional maximum likelihood estimation method used by the conditional logit model (clogit command in Stata). Standard errors are corrected for heteroscedasticity and clustered at the firm level.

\section{[Insert Table 3 here]}

Table 3 column (1) shows that larger and older firms and firms with a higher market-to-book ratio are more likely to see their CEOs accepting a new outside directorship. I use the ROA along with buy-and-hold stock return in the previous 12 months to measure firms' operating performance and financial performance, respectively. The positive coefficient of ROA indicates that firms supplying CEO directors tend to have better performance in the past. This is consistent with the prior literature reporting that CEOs with a better track record are more desirable candidates in the director labor market. CEOs in financial firms (firms with one-digit SIC of 6) are less likely to serve on outside boards. This is because in the sample only about $8 \%$ of CEOs' firms are financial firms.

I add variables that capture CEOs' characteristics and corporate governance structure in column (2). Institutional ownership and the presence of blockholder investors do not have a statistically significant association with CEOs' acceptance of outside directorships. CEOs in firms with more independent directors are more likely to accept new directorships. A 
CEO's tenure is commonly used to measure CEO's power. The negative coefficient of CEO's tenure is inconsistent with the agency hypothesis predicting that CEOs with longer tenure tend to have more power in the boards and are more likely to extract economic rent from outside directorships. While it is possible that CEOs with longer tenure already have outside directorships in hand and thus less likely to accept another one, the positive coefficient of the number of CEO's existing outside directorships leads me to reject this conjecture.

Older CEOs are more likely to become outside directors. This is probably because older CEOs have more experiences and thus are more desirable directors to other firms. CEOs over 62 years old are less likely to accept outside directorships, suggesting that CEOs near retirement are not more likely to take director positions as a transition for future jobs after retirement.

The CEO's total compensation amount and their equity-based (stocks and stock options) compensation percentage do not have statistically significant coefficients. The CEO's beneficial ownership has a statistically significantly negative coefficient, indicating that CEOs with a higher beneficial ownership are less likely to accept outside directorships. Since CEOs with a higher beneficial ownership bear more costs associated with value-reducing events, this result suggests that the CEOs' financial tie with firms' value plays a role in the CEOs' acceptance of outside directorships. 


\subsection{Stock Price Reaction to CEOs' Outside Directorship Appointments}

In this section, I analyze the stock price reaction to CEOs' own firms around the time of the CEOs' outside directorship appointments. If investors think that CEOs' outside director experiences benefit their own firms, the reaction is expected to be positive on average. In contrast, if investors view outside directorships as harmful to shareholders, the reaction is expected to be negative on average.

I collect announcement dates for CEOs' directorships from Factiva and appointing firms' proxy statements (DEF 14A forms) and 8-K forms. I obtain regulatory filings from the SEC's EDGAR website. I start with 804 appointments. For each proxy statement of an appointing firm during the appointment year, I search whether the CEO of interest is listed as a director nominee in the statement. If the $\mathrm{CEO}$ is named among a slate of director nominees, I use the proxy filing date as the announcement date. For an 8-K form conveying appointment information, if there is a separate press release appended (Exhibit 99.1), I use the announcement date of the press release. If there is no separate press release, I use the filing date of the 8-K form. Next, I search the earliest date that can be found in Factiva for all director appointments. For each appointment, I choose the earliest date from either Factiva, DEF $14 \mathrm{~A}$ forms, or the 8 -K forms as the announcement date 11 I exclude appointments that are related to takeovers, merger \& acquisitions, spin-offs, or major restructuring activities. To obtain a cleaner announcement effect, I exclude announcement dates that are within two days of other possible confounding events of the CEOs' own firms, such as earnings announcements, mergers, acquisitions, 8-K form filings, and 13G/13D form filings. The final event study sample includes 594 announcements.

\section{[Insert Table 4 here]}

\footnotetext{
${ }^{1}$ Director nominations almost always end with formal appointments in annual shareholder meetings (Cai, Garner, and Walkling, 2009). Directors can be nominated or appointed any time of the year and receive formal approval at the following annual shareholder meeting. I use the earliest public notification date of a director's first nomination or appointment or election as the announcement date regardless of shareholder voting status.
} 
I compute market-adjusted cumulative abnormal returns (CARs) as the difference between cumulative stock returns and the CRSP value-weighted market returns. The market-adjusted CARs over the $(-1,1)$ day event window of CEOs' firms have mean and median values that are not statistically different from zero. The CARs are also not statistically different from zero when I use the $(-5,1),(-5,5),(-10,1)$, and $(-10,10)$ day event windows. The results are similar to those of Fich (2005) and Perry and Peyer (2005) who find statistically insignificant CARs for the CEOs' own firms.

The CARs over the $(-1,1)$ day event window for appointing firms are not statistically different from zero in mean or median values. These results are consistent with those of Fahlenbrach et al. (2010), who find statistically insignificant announcement effect for appointing firms.

The CARs over the $(-1,1)$ day window for the CEOs' own firms and the appointing firms have a correlation coefficient 0.14 that is significant at the $1 \%$ level. This positive association suggests that CEOs' outside directorships are viewed as beneficial or detrimental to both sides at the same time. Investors do not view CEOs' directorships as beneficial to the appointing firms while detrimental to CEOs' own firms or vice versa.

Next, I examine cross-sectional variations in CARs over the $(-1,1)$ day window. In Table 4 Panel B, Panel C, and Panel D, I report mean values and their differences. I use asterisks $\left(^{*}\right)$ to indicate the statistical significance for mean values in each group and the differences across groups.

I find that, when CEOs do not hold any outside directorship before taking one, the average CAR is $0.27 \%$ and significant at the $10 \%$ level. This suggests that investors on average view CEOs' first outside directorships as beneficial to their own firms. When CEOs take the second outside directorships, the average CAR by itself is not statistically different from zero, though it is statistically significantly more negative than the average CAR for CEOs' first outside directorships. When CEOs take the third and fourth outside directorships, I do not find statistically significantly more negative stock price reaction. The results suggest that external board service can be beneficial to CEOs' own firms, but the costs of additional responsibilities may wipe out the benefits when CEOs are overcommitted.

To examine the correlations between CARs and the agency costs, I divide sample into 
one group with higher agency costs and the other group with lower agency costs based on three proxies to the agency problem-CEO's ownership, presence of blockholders, and Entrenchment index (E index). CEOs with lower beneficial ownership are less financially tied to their firms' value and potentially have less incentive to maximize shareholders' value. The presence of blockholders and a low E index are generally associated with improved monitoring (Edmans, 2014; Bebchuk, Cohen, and Ferrell, 2008).

As shown in Panel C, I only find a statistically significantly negative average CAR among firms with a relatively high degree of CEO's ownership, which is not consistent with the agency hypothesis. Furthermore, I find that the presence of a statistically significantly more negative stock price reaction to CEOs' second directorships (compared to their first) does not only exist in firms with potentially high agency costs, for example, firms with a low CEO's ownership. It also exists in firms with potentially low agency costs, for example, firm with blockholder investors and a low E index. In sum, there is little evidence suggesting that holding multiple outside directorships destroys firms' value based on investors' perceptions.

The positive stock price reaction to CEOs' first outside directorships can come from a positive signal of CEOs' ability and/or a material beneficial effect on the following operating performance. If the announcements simply send a positive signal of CEOs' ability to the market, I do not expect that the CARs will have cross-sectional variations based on the benefit hypothesis. To examine whether at least part of the announcement effect reflects investors' expectation of changes in subsequent operating performance, I study the cross-sectional variations in CARs with respect to four potential channels.

When CEOs are appointed by larger firms (as measured by market value) compared to their own firms, the average CAR is statistically significantly more positive than those when CEOs are appointed by smaller firms. The positive stock price reaction may reflect investors' expectation that directorships in larger firms may help CEOs learn more and make better decisions in their own firms. The positive reaction may also reflect certification of CEOs' ability considering that larger firms are willing to hire them as outside directors.

When the CEOs' firms and the appointing firms operate in vertically related industries, the average CAR by itself is statistically significantly positive and also more positive than the cases when CEOs' firms and appointing firms do not operate in vertically related industries. 
The differences in mean values are not statistically different from zero when CEO's firm and the appointing firm are in the same industry or informationally related. There is no reason to think that CEOs' ability varies based on whether the appointing firms operate in related industries. These results provide some support for the beneficial effect on operating performance through the information sharing channel.

The changes in CEO's network are not associated with statistically significant changes in stock prices. It is possible that the changes are not big enough to have a material effect. I find that the average CAR is not statistically different from zero even for larger changes in CEOs' network (results not tabulated)..

The average CAR is statistically significantly positive if the CEOs' firms enter a new business contract with the appointing firms, despite the fact that most of these contracts are small in size. However, the mean values are not statistically more positive than they are for those cases where no new business contracts are established.

Overall, the results of the event study provide some support for the benefits obtained from the CEOs' outside directorships applicable to the performance of CEOs' own firms, and relieve some concerns that more than one outside directorship can distract CEOs from their main jobs and be detrimental to firms' value.

A potential drawback of the event study results from the difficulty of obtaining accurate announcement dates. It usually takes firms a long time to seek outside directors, especially when a director is an active $\mathrm{CEO}$ in another firm. The dates I find are possibly not the earliest dates that the investors learn about the appointments. To overcome this potential drawback, I complement this evidence by studying the changes in operating performance of the CEOs' own firms. 


\subsection{Change in Operating Performance Following CEOs' Outside Directorship Appointments}

In this section, I examine the changes in operating performance of the CEOs' own firms following CEOs' directorship appointments and determine whether there is a causal link between the two.

\subsection{Change in operating performance, OLS results}

I use ROA to measure operating performance. ROA is defined as the operating income before depreciation (Compustat item OIBDP) divided by book value of total assets at the beginning of the year. I use operating income instead of net income (Compustat item NI) for two reasons. First, operating income is less affected by unusual/extraordinary items and more closely reflects day-to-day operations. Second, corporate events often result in changes in capital structure, which affect interest expenses and consequently net income, but may leave operating income unaffected if firms' operations do not change (Barber and Lyon, 1996).

I use a Diff-in-Diff (DID) approach to examine the changes in ROA for treated firms after CEOs' outside directorship appointments relative to control firms. Treated firms are firms whose CEO becomes an outside director in another firm. The firms whose CEO does not have a new outside directorship appointment in the entire sample period are control firms. In other words, treated firms in non-treated years are excluded. Control firms are used to partially control for firm and CEO characteristics that are correlated with both firms' participation decision and operating performance.

For each firm observation at year t, I require CEOs to be in term at least one year before and two years after year t. If CEOs' outside directorships affect subsequent operating performance, it may take more than one year to realize. I require CEOs to be in term one year before, because otherwise, the changes in ROA may simply reflect the turnover of CEOs. 
The parallel trend assumption is important to draw any meaningful conclusions from the DID method. For every firm-year observation, I plot the mean and median values of ROA in treated firms and control firms from three years before to three years after in Figure 1. The two groups of firms have a similar level in ROA before year $t$.

\section{[Insert Figure 1 here]}

The DID Panel ordinary least squares (OLS) regression model is:

$$
\Delta R O A_{i, t-3} \text { to } t+3=\beta_{1} \text { Treat }_{i, t}+\beta_{2} \Delta X_{i, t-1}+\beta_{3} \Delta S_{s, t-1}+f_{\text {ind }, t}+\epsilon_{i, s, t}
$$

where i, s, and t index firms, firms' headquarters states, and fiscal years, respectively. For each firm $\mathrm{i}$ in fiscal year $\mathrm{t}$, the dependent variable is the average ROA from year $\mathrm{t}+1$ to $\mathrm{t}+3$ minus the average ROA from year $\mathrm{t}-3$ to $\mathrm{t}-1$. Since CEOs are required to be in term at least in year $t-1, t, t+1$, and $t+2$, the ROA in other years can be missing. If the CEO in any other year is different from the CEO in year t, I define the ROA in that year as missing. This adjustment ensures that the changes in ROA do not simply reflect changes in management. The average ROA only accounts for years with non-missing values. For example, if the ROA in year $t+3$ is missing, the average ROA from year $t+1$ to $t+3$ would be the average ROA from year $\mathrm{t}+1$ to $\mathrm{t}+2$.

I use the average ROA over three years instead of ROA in a single year for two reasons. First, changes in ROA following CEOs' outside directorship appointments may need multiple years to take place. It can be less informative or misleading just to use year $t+1$. Second, some firms have volatile ROA over time. Taking an average over three years mitigates the volatility of performance of some firms, which may bias the estimation results.

In the DID regression, independent variables included must be unaffected by the treatment status. Accordingly, I include independent variables that are realized in year t-1. On the right-hand side of the regression equation, treat dummy is an indicator for treated firms in year t. $\Delta$ is the first-difference operator. $X_{i, t-1}$ is the vector of time-varying firm-level control variables, including natural log of firm size, market-to-book ratio, total investment scaled 
by lagged assets, and sales growth rate. These firm characteristics are potentially correlated with both treatment participation and the outcome variable - operating performance.

Since firms' operating performance can be correlated with local economic conditions, I include two county-level variables. $S_{s, t-1}$ is the vector of county-level control variables, including natural log of per capita personal income and unemployment rate. I map each firm's zip code of its business address, where the headquarters is located, to the corresponding county using a 2010 correspondence file from the Census Data Center ${ }^{1}$ County-level per capita personal income data is from the US Bureau of Economic Analysis. County-level unemployment rate data is from the US Bureau of Labor Statistics. Since one zip code can be mapped to more than one county in one year, I use population-weighted average of per capita personal income and unemployment rate for each firm-year observation.

Compustat has zip codes for firms' headquarters. However, Compustat only reports firms' current headquarters locations, not historical locations. Changes in firms' headquarters locations may lead to inaccurate estimates. To remedy this issue, I search the SEC's EDGAR website and extract historical locations from firms' 10-K filings for each year. I use firms' historical zip codes for all the subsequent empirical tests in this paper. About $30 \%$ of firms have zip codes in the previous years which are different from their current ones.2 ${ }^{2}$ The pervasiveness of change in headquarters locations suggests that using the current location for all historic years for a firm can potentially be problematic.

I include SIC2 industry-year fixed effects to remove unobserved time-varying industry conditions. Gormley and Matsa (2013) recommend using fixed effects over industry-adjusted ROA because the latter approach can produce inconsistent estimates and distort statistical inferences. I do not include firm fixed effects because they are differenced out in this first-differencing setup. Standard errors are clustered at firm level. All variables are winsorized at $1 \%$ and $99 \%$ to avoid outliers.

First-differencing has two advantages over the approach using an empirical specification

\footnotetext{
${ }^{1}$ The Census Data Center also has the 2000 zip code to county correspondence file. I choose the 2010 file because it covers more zip codes. However, the results are qualitatively similar if I use the 2000 correspondence file. I choose to use county-level variables rather than metropolitan area-level variables because many firms are not located in metropolitan areas.

${ }^{2}$ Heider and Ljungqvist (2015) report that in their sample about $15 \%$ of firms have headquarters in a different state from their current one. I expect that when I use more a granular location identifier, such as zip code, more firms would have a change in location at some point in the past.
} 
including the level of ROA and controlling for firm fixed effects. First, first-differencing easily accommodates the 2SLS regressions and econometric models in the cross-sectional analyses later. It reduces one dimension of difference in the regression analyses. Second, using the change in average ROA allows me to collapse observations over multiple years and avoids the unbalanced panel issue in level regressions (Imai and Kim, 2013).

\section{[Insert Table 5 here]}

The OLS regression results with various econometric specifications are reported in Table 5. I only include the variable of interest - treat dummy - as the independent variable without any controls in column (1). The coefficient is positive but not statistically significant at the conventional level. In column (2), I add industry-year fixed effects to control for changing industry conditions. The coefficient for treat dummy has a positive value of 0.007 that is significant at the $10 \%$ level. In column (3), I control for firm size and market-to-book ratio. Sequentially, in column (4), I add change in investment scaled by lagged assets value and change in sales growth rate to control for growth opportunities. In column (5), I control for local economic conditions. None of the coefficients for treat dummy in these three columns is statistically significant.

The OLS regression results suggest that there is no statistically significant association between CEOs' outside directorship appointments and changes in firms' operating performance in subsequent years.

\subsection{Identification: instrumental variable}

One challenge to the DID approach and the performance analyses is posed by the endogeneity of CEOs' outside directorship appointments. The decision to take outside directorship appointments depends on the trade-off between benefits and costs whether it is from the CEOs' perspective or the shareholders' perspective. The trade-off between benefits 
and costs is correlated with the characteristics of firms and CEOs, and these firm-specific and CEO-specific characteristics are likely to be correlated with operating performance as well. For example, more capable CEOs also appear more desirable as directors to other firms and are more likely to obtain appointments. At the same time, more capable CEOs are also likely to deliver better performance in their own firms. Omitting the CEOs' ability from analysis may introduce a positive bias to the estimated relation between CEOs' outside directorship appointments and changes in performance of their own firms. On the other hand, CEOs in firms with more agency problems are likely to take more directorships than desirable for shareholders, and may deliver worse performance at the same time. Omitting governance structure may introduce a negative bias to the estimation results. Thus, it is not clear from economic reasoning in which direction my results may be biased.

To address the endogeneity concern, I use an instrumental variable that provides a plausibly exogenous variation in firms' participation decision.

The instrumental variable is based on firms' geographic location. I use the distance to the headquarters of the appointing firm as the instrumental variable following Fahlenbrach et al. (2010). I calculate the distance between two firms' headquarters based on their historical five-digit zip codes obtained previously. I take the log of the distance to address the left skewness of this instrumental variable. I choose the headquarters location of a firm because this is the location where the CEO works most of the time. The logic of this instrument is that CEOs have high opportunity costs of time and prefer to join the boards of nearby firms. I exclude any firms that are located in Hawaii or Alaska to avoid outliers in the distance. Less than $1 \%$ of firms in the sample are located in these two states, and the results are not affected by this exclusion.

Since control firms do not have corresponding appointing firms, I pair each treated firm to all control firms in the same SIC2 industry and the same year. I match on industry because appointing firms often cite directors' expertise or experiences in a certain industry as one of the most valued qualifications for being outside directors. Except industry, I do not impose any other requirement to pair control firms and treated firms because matching on covariates may change the distribution of certain firm characteristics among control firms. Without knowing which observables are more important, plus the fact that I cannot match on 
unobservable characteristics, I choose not to match on any covariate initially. Regression and matching are essentially both control strategies. Thus,later I will sequentially add covariates in regressions to show how the estimation results change with control variables.

\section{[Insert Figure 2 here]}

Figure 2 shows the distribution of the distance to the appointing firms in miles for treated firms and paired control firms. CEOs are clearly often appointed to nearby firms as outside directors. A large proportion of treated firms are located within 200 miles of the appointing firms.

The ideal instrument should be correlated with CEOs accepting outside directorships and affect the performance of CEOs' own firms only through the outside directorship appointments. One potential concern is that firms located in big cities have more firms in close proximity and the CEOs in these firms are more likely to join nearby firms. The location of a firm can also affect its operating performance through local economic conditions, which would violate the exclusion restriction requirement. County-level personal income and unemployment rate already control for observed local economic conditions. Any remaining confounding variables must be orthogonal to these county-level controls. It is unlikely that the unobservable measures of local economic conditions are orthogonal to these two variables. Another concern can come from a possible co-movement in ROA between a CEO's firms and the appointing firm located in the same area. However, Pirinsky and Wang (2006) show that only stock returns of firms headquartered in the same geographic area tend to move together and this co-movement does not apply to economic fundamentals such as earnings.

The two-stage least squares (2SLS) DID regressions $3^{3}$ are:

$$
\begin{aligned}
& \text { 1st stage }: \text { Treat }_{i, t}=\gamma_{1} \ln (1+\text { distance to appointing firm })_{i, t}+\gamma_{2} \Delta X_{i, t-1} \\
& +\gamma_{3} \Delta S_{s, t-1}+f_{\text {ind }, t}+u_{i, s, t} \\
& \text { 2nd stage }: \Delta R O A_{i, t-3} \text { to } t+3=\beta_{1} \widehat{\text { Treat }}_{i, t}+\beta_{2} \Delta X_{i, t-1}+\beta_{3} \Delta S_{s, t-1}+f_{i n d, t}+\epsilon_{i, s, t}
\end{aligned}
$$

\footnotetext{
${ }^{3}$ In execution, I run all 2SLS regressions in one step using Stata command reghdfe to ensure that the standard errors are adjusted correctly.
} 
To compare with the panel OLS results in Table 5, I use the same order of specifications in Table 6. $4^{4}$ In this paired sample, standard errors are clustered at the treated firm level because standard errors of firms paired with the same treated firm are in the same industry and the same year are likely to be correlated.

\section{[Insert Table 6 here]}

I report the first-stage regression results in Table 6 Panel A. The instrument has a negative coefficient in all specifications, which means that CEOs are more likely to join the boards of firms that are geographically closer to their own firms. This is consistent with the prediction. In column (2)- (5), the control of industry-year fixed effects and other independent variables has little effect on the coefficients of the instrument, suggesting that the distance to an appointing firm matters to a firm's participation decision and it isolates a fairly robust exogenous part of estimated probability. Also, the F statistics of all the first-stage regression specifications exceed the commonly used threshold of 10 for a strong instrumental variable, which indicates that the instrument satisfies the relevance condition. Such good properties of this instrument elevate the credibility of causal inferences I will later draw.

In Table 6 Panel B, I report the second-stage results. In all of the specifications, the instrumented treat dummy variable does not have a statistically significant coefficient. The IV results indicate that the average performance effect of CEOs' outside directorship appointments is not different from zero.

\footnotetext{
${ }^{4}$ The reader may be concerned that the sample I use for the OLS regressions in Table 5 and the paired sample I use for the 2SLS regressions in Table 6 are different, which makes them not comparable. I report Panel OLS regression results in this paired sample in the Appendix table A1. The OLS results in these two samples are qualitatively similar.
} 


\subsection{Robustness tests}

\subsubsection{Other measures of performance}

In addition to the ROA, return on sales (ROS), also called profit margin, is also a frequently used measure for operating performance. I define this variable as net income divided by sales over the same year. I use the same 2SLS regressions in the paired sample. As shown in Table 7 column (1), the coefficient of the instrumented treat dummy is not statistically significant.

Operating performance measures the operation efficiency within a period, while accounting performance and market-to-book asset ratio (also called Tobin's Q) includes investors' expectation of future operations. If CEOs' outside directorship appointments have an average zero effect on subsequent operations, then there is no reason to expect a non-zero average effect on subsequent accounting performance or Tobin's Q. I use buy-and-hold stock returns to measure accounting performance. Tobin's $\mathrm{Q}$ is the ratio of market value of assets to book value of assets. The results in column (2) and (3) confirm my prediction.

\section{[Insert Table 7 here]}

\subsubsection{Observation window}

It may take several years for operations to change even if CEOs' firms benefit from their outside directorships. Using the average of operating performance from year $t+1$ to $t+3$ may fail to capture the performance effect. To mitigate this concern, I change observation windows in the post-appointment period. In column (4), I use the average ROA from year $t+2$ to $t+4$. In column (5), I use the average ROA from year $t+3$ to $t+5$. The coefficient of treat dummy is positive and significant at the $10 \%$ level if I use the $[\mathrm{t}+3, \mathrm{t}+5]$ window. This result suggests that it may take more than three years for the benefits of CEOs' outside directorships to be reflected in an improvement in operating performance. A caveat of this result is that ROA can get noisier when I use a longer observation window. 


\subsubsection{Serial outside directorship appointments}

Although more than $80 \%$ of CEOs in my sample only hold one outside directorship appointment during the sample period, some CEOs take more than one. If there are less than three years in the middle of two appointments for the same CEO, the change in ROA calculated around the first appointment can also pick up the effect of the second one. When this happens, I only keep the first appointment. The results are not affected by this adjustment, as shown in column (6).

\subsubsection{Firms located in big cities}

As I stated previously, CEOs in firms located in big cities are more likely to become outside directors in other firms. It may be a concern that CEOs working in big cities are more talented and have more resources, which may obscure the negative effect of CEOs' outside directorships. I therefore exclude firms from the top three cities nationally in which most treated firms are located-New York, Houston, and Chicago. Column (7) shows that excluding these three cities does not change the results qualitatively. 


\subsection{Negative Performance Effect of (Multiple) Outside Directorships}

\subsection{Empirical design}

My previous results suggest that the average effect of CEOs' outside directorship appointments on the performance of their own firms is zero, however, there can be heterogeneity in this effect across firms. In this section, I analyze the cross-sectional variations in the performance effect.

I use the same 2SLS regression setup and interact treat dummy with different conditioning variables that I also use to analyze cross-sectional variations in the performance effect. With two endogenous variables, treat dummy and its interaction with a conditioning variable, I use the natural log of distance and its interaction with the same conditioning variable as instrument variables 1

The 2SLS regression model is:

$$
\begin{aligned}
\text { 1st stage } & : \text { Treat }_{i, t}=\gamma_{1} \ln (1+\text { distance to appointing firm })_{i, t}+\gamma_{2} \Delta X_{i, t-1} \\
& +\gamma_{3} \Delta S_{s, t-1}+f_{\text {ind, },}+u_{i, s, t} \\
\text { 2nd stage } & : \Delta R O A_{i, t-3} \text { to } t+3=\beta_{1} \widehat{\text { Treat }}_{i, t} \times C_{i, t}+\beta_{2} \widehat{\text { Treat }}_{i, t}+\beta_{3} C_{i, t}+\beta_{4} \Delta X_{i, t-1} \\
& +\beta_{5} \Delta S_{s, t-1}+f_{\text {ind,t }}+\epsilon_{i, s, t}
\end{aligned}
$$

where $\mathrm{C}$ is the conditioning variable.

In this section, I first study whether CEOs working at firms with higher agency costs take outside directorships at the expense of shareholders, I then investigate whether multiple outside directorships hurt CEOs' own firms. In section 9, I will use the same empirical design to examine whether firms can benefit from CEOs' outside directorships.

\footnotetext{
${ }^{1}$ The same principle applies when I interact treat dummy with two variables in later analyses.
} 


\subsection{Agency costs}

The agency hypothesis argues that CEOs can pursue private benefits at the expense of shareholders in their own firms. If CEOs' private benefits are the principal reasons for their acceptance of outside directorships, then CEOs with less aligned interests with shareholders and CEOs at firms with ineffective monitoring are more likely to do this.

To test the agency hypothesis, I examine whether CEOs' outside directorships have a negative performance effect in firms whose CEO's ownership is lower than sample median, in firms without blockholder investors, and in firms with high E index. The agency proxy is an indicator for firms with higher agency costs. The results are reported in Table 8.

\section{[Insert Table 8 here]}

In column (1), the coefficient for treat dummy is positive and significant at the $10 \%$ level. This indicates that firms with a relatively higher CEO's ownership show an improvement in performance during the three years after CEOs' outside directorship appointments. The negative coefficient of the interaction term means that, compared to firms with a higher CEO's ownership, firms with a lower CEO's ownership have a smaller increase in ROA. The change in ROA within these firms is the sum of the coefficient of treat dummy and the coefficient of the interaction term. The sum is negative but not statistically different from zero, meaning that firms with a relatively lower CEO's ownership do not suffer a performance decline after CEOs take their directorship appointments.

As shown in column (2), firms with at least one blockholder owner show an improvement in performance during the post-appointment period. For firms without any blockholder investor, the changes in performance are not statistically different from zero.

In column (3), the positive coefficient of treat dummy indicates that firms with fewer anti-takeover provisions show an improvement in performance. The coefficient of the interaction term is negative and significant at the $5 \%$ level, but the sum of these two coefficients is not statistically different from zero. Thus, for firms with more anti-takeover provisions, the changes in performance post-appointment are not statistically different from zero. 
The results in this section do not support the agency hypothesis predicting that higher agency costs are associated with worse performance following CEOs' outside directorship appointments.

\subsection{Multiple outside directorships}

Outside directorships potentially make CEOs busier and may distract them from the fiduciary duty they owe to their own firms. This can be especially costly when CEOs hold more than one outside directorship at the same time. In this section, I examine the marginal performance effect of CEOs' new outside directorships when they already hold one, two, and three directorships, respectively.

[Insert Table 9 here]

I report the results in Table 9 Panel A. In column (1), as a baseline, I test when CEOs do not hold any outside directorship before accepting a new appointment, whether their own firms' performance changes in the subsequent three years. In column (2), I test whether their own firms perform worse in the subsequent three years when CEOs already hold one outside directorship before accepting a new appointment. For this column, I exclude all firms whose CEO holds more than one outside directorship. In column (3) and (4), I exclude all firms whose CEO holds more than two and three outside directorships, respectively. Since there are few firms whose CEO already holds four outside directorships prior to the new appointment, I exclude these firms because the sample size may not be large enough for meaningful statistical inferences.

In column (1), the coefficient of the interaction term is positive and significant at the $10 \%$ level, indicating that the average performance effect of CEOs' first directorships is statistically significantly more positive than their subsequent directorships. The marginal

effect of CEOs' first directorships is the sum of the coefficient of the interaction term and the 
coefficient of treat dummy, and it is positive and significant at the $10 \%$ level. This finding is consistent with my prior event study result that the average abnormal returns are positive after the announcements of CEOs' first directorship appointments.

In column (2), the marginal effect of CEOs' second directorships is the sum of the coefficient of the interaction term and the coefficient of treat dummy. The sum is not statistically significant, indicating that on average the performance effect of CEOs' second outside directorships is zero.

In column (3), the marginal effect of CEOs' third directorships is positive and significant at the $10 \%$ level, indicating that on average the performance effect of CEOs' third outside directorships is positive. The marginal effect of CEOs' fourth outside directorships is not statistically different from zero, as shown in column (4).

In sum, the performance effect of CEOs' first outside directorships is positive. The performance effect of CEOs' subsequent outside directorships may also be positive. It is not clear why CEOs' second and fourth outside directorships do not have a statistically significant performance effect, but their third directorships seem to improve performance. Overall, the results here indicate that there is no performance decline for CEOs who hold multiple directorships.

According to the agency hypothesis, CEOs are more likely to hold more outside directorships than the optimal level for shareholders when CEOs have fewer incentives to maximize shareholders' value or when they face ineffective monitoring from the board and investors. As a result, CEOs' multiple outside directorships can be more detrimental to shareholders in these cases.

I examine whether CEOs' multiple outside directorships result in worse performance in firms with higher agency costs. The results are reported in Table 9 Panel B. The agency proxy is an indicator for firms with a lower CEO's ownership than sample median in column (1) and (2), for firms without a blockholder investor in column (3) and (4), and for firms with E index greater than 3 in column (5) and (6), respectively. For the firms meeting these conditions, the maximum number of existing outside directorships for the CEOs is three.

In column (1), the marginal effect of CEOs' second directorships in treated firms with CEO's ownership below sample median is the sum of coefficients of the triple interaction 
term and the interaction term of treat dummy and the agency proxy compared to other treated firms. The sum is not statistically different from zero. The same result applies to CEOs' third directorships, as shown in column (2). Thus, compared to other treated firms, I do not find a more negative performance effect of CEOs' outside directorships when CEOs have a relatively low beneficial ownership. I find similar results when firms do not have blockholders and when firms have a relatively high E index.

When treated firms do not have blockholders, the marginal effect of CEOs' second directorships is the sum of four coefficients- the coefficients of treat dummy, its interaction with the agency proxy, its interaction with the variable $\mathrm{C}$, and the triple interaction term. The marginal effect of CEOs' second directorships is negative and significant at the $5 \%$ level, but the marginal effect of CEOs' third directorships is positive and significant at the $5 \%$ level. However, as I do not obtain similar results for the other two measures of agency costs, and it is not clear why the marginal effects of CEOs' second and third directorships appear opposite to each other, I still cannot claim that more than one outside directorship is harmful to CEOs' own firms.

Overall, I do not find enough evidence suggesting that the performance effects of more than one outside directorship are (more) negative in firms with potentially higher agency costs. It is possible that firms endogenously choose the optimal ownership and governance structure, and thus these proxies to agency costs do not have an association with the performance effect of CEOs' outside directorships.

\subsection{Expected number of outside directorships}

Until now, I have treated the number of CEOs' existing outside directorships as an exogenous variable in the regressions. However, the number of such appointments is likely to be endogenously chosen by CEOs and the boards of their own firms. Consequently, any additional outside directorship should have a negative performance effect only when the total number of CEOs' outside directorships exceeds investors' prefrence.

To obtain the number of directorships CEOs are expected to hold, I follow Perry and 
Peyer (2005) and regress the number of outside directorships held by CEOs on firm and CEO characteristics in a Poisson regression model. The predicted values are the expected numbers of CEOs' existing outside directorships. The Poisson regression results are reported in Appendix Table A3. CEOs hold more outside directorships if they are older but not near retirement age or if they work at larger and older firms with a lower market-to-book ratio and a lower sales growth rate. CEOs' ownership is negatively associated with the number of outside directorships only when the ownership level surpasses a certain threshold, for example, 20\%. Board size, board independence ratio, and whether a CEO is also the Chairman in her own firm do not have a statistically significant relation with number of outside directorships held by CEOs.

\section{[Insert Table 10 here]}

I use the difference between the actual number and estimated number of CEOs' existing outside directorships as the excess number of directorships. This value ranges between -3 and 4 . I test whether firms with a positive excess number underperform other firms. Consistent with the prediction, as shown in Table 10 column (1), I find that when CEOs already hold more outside directorships than the expected number and continue taking an additional one, their own firms underperform other firms in the subsequent three years. The average difference is significant at the $10 \%$ level. However, among these firms themselves, the marginal effect of an additional directorship, which is represented by the sum of coefficients of treat dummy and its interaction with the agency proxy, is not statistically different from zero.

Again, I do not find that holding more than the expected number of outside directorships leads to a decline in performance at firms with potentially more agency problems or a greater decline in performance compared to other treated firms, as shown in columns (2), (3), and (4).

Overall, my results do not support the claim that holding more outside directorships than expected is detrimental to the performance of CEOs' own firms. 


\subsection{Ex-post governance: CEO turnover}

Thus far, I have found little evidence suggesting that holding multiple outside directorships leads to a decline in the performance of CEOs' own firms. However, if CEOs insist on taking more than necessary outside directorships, they may face the threat of forced turnover if the additional commitment turns out to be a distraction.

To find out whether a decline in operating performance after CEOs' directorship appointments could lead to a turnover of their CEO jobs, I test whether the changes in ROA of the CEOs' own firms are associated with CEOs' turnover in the next five years. I conduct this analysis in the paired sample. The 2SLS regression model is:

$$
\begin{aligned}
& \text { 1st stage : } \text { Treat }_{i, t}=\gamma_{1} \ln (1+\text { distance to appointing firm })_{i, t}+\gamma_{2} X_{i, t-1}+f_{\text {ind, } t}+u_{i, s, t} \\
& \text { 2nd stage : CEO turnover }{ }_{i, t+1} \text { to } t+5=\beta_{1}{\widehat{\text { treat }_{i, t}}} \times \text { Negative } \Delta R O A_{i, t-3} \text { to } t+3 \text { dummy } \\
& \left(\Delta R O A_{i, t-3} \text { to } t+3\right)+\beta_{2} \widehat{\text { Treat }}_{i, t}+\beta_{3} \text { Negative } \Delta R O A_{i, t-3} \text { to } t+3 \text { dummy } \\
& \left(\Delta R O A_{i, t-3} \text { to } t+3\right)+\beta_{4} X_{i, t-1}+f_{i n d, t}+\epsilon_{i, s, t}
\end{aligned}
$$

The difference between this model and the regression model (8.1) lies in the second stage. In the second stage, dependent variable is an indicator for CEOs who are turned over in their own firms within the next five years. The conditioning variable is an indicator for a negative change in ROA or the change in ROA. The coefficient $\beta_{1}$ of the interaction term measures the relative sensitivity of CEOs' turnover to change in operating performance after CEOs' directorship appointments. The readers should note here that the change in ROA is correlated with treat dummy. Here I focus on the difference in turnover-performance sensitivity between CEOs who hold outside directorship appointments and CEOs that do not.

I rely on the end dates of CEOs' terms provided in the BoardEx database to define CEOs' turnover in their own firms. Since attempting to distinguish forced from voluntary turnovers based on announcements may underestimate the predictive power of performance Jenter and Lewellen, 2017), I include all turnovers regardless of disclosed reasons. Since including retiring CEOs potentially introduces a bias in estimating the turnover sensitivity induced by 
poor performance, I exclude CEOs over 62 years old. I control for firm characteristics-firm size and market-to-book ratio as well as CEOs' characteristics, such as the number of years they have held their position as CEO and their age. I add industry-year fixed effects to control for changing industry conditions.

\section{[Insert Table 11 here]}

In Table 11 column (1), the coefficient of the negative change in the ROA dummy is positive and statistically significant at the $1 \%$ level, indicating that CEOs who perform more poorly are more likely to lose their jobs. However, the coefficient of the interaction term is not statistically significant. These results suggest that CEOs with outside directorships are not more likely to get turned over due to poor performance than are other CEOs.

Agency problems may already exist at firms whose CEOs are allowed to accept an outside directorship even if it is perceived to have a detrimental effect on the shareholders; CEOs can protect themselves from turnover by influencing the boards. I cannot find a higher turnover-performance sensitivity for CEOs with outside directorship appointments, possibly for these reasons among others.

To check this possibility, I examine whether CEOs in firms with blockholders and a lower E index are more likely to be turned over in response to worse performance after CEOs' directorship appointments. I do not examine CEOs with greater ownership because CEOs' internal incentive is not an outside governance mechanism. In column (2) and (3), neither coefficient of the triple interaction term is statistically significant., suggesting that even in firms with potentially lower agency costs that CEOs with new outside directorship appointments are not more likely to be turned over due to poor performance.

In column (4)-(6), I use the continuous variable - change in ROA - as the conditioning variable. The results are similar.

In sum, I do not find evidence showing that CEOs are more likely to be turned over if their outside directorships are associated with a decline in operating performance of their own firms. 


\subsection{Termination of outside directorships}

Replacing CEOs can be very costly for firms. If the responsibilities from outside directorships make CEOs unable to be fully devoted to their own firms, a potentially less costly approach is to force the CEOs to drop their directorships. However, due to the difficulty of distinguishing between CEOs' voluntary resignations, resignations forced by the boards of CEOs' own firms, and forced turnover by the boards of the appointing firms, I cannot make any causal conclusions regarding this issue. In this section, I provide univariate statistics, regression results, and anecdotal evidence to examine the termination of CEOs' outside directorships.

On average, CEOs are 56 years old when they accept new outside directorship appointments and hold the directorships for 8.8 years. The average tenure of CEOs' outside directorships is slightly longer than the average tenure of non-CEO outside directors - 7.4 years - in the ISS database. For 166 out of 804 (about 21\%) appointments, CEOs end their directorships actively or passively while they are still in the CEO position. These CEOs on average hold outside directorships for about five years. For other CEOs who still hold outside directorships after they retire from the CEO position, they hold those directorships an average of ten years ${ }^{2}$

I then use regressions to examine the association between changes in ROA of CEOs' own firms and turnover of outside directorships in the subsequent five years. Since I can only identify directorship turnovers for CEOs with actual outside directorship appointments, for this analysis I only include the treated firms. Considering that the turnover of CEOs' outside directorships can be confounded by the turnover of CEO positions in their own firms, I require that CEOs hold the executive position in the five years after directorship appointments. As in the previous analyses of CEO turnover, I exclude CEOs over 62 years old.

\section{[Insert Table 12 here]}

\footnotetext{
${ }^{2}$ I calculate the length of director tenure at the end of year 2017. If the CEO is still holding the outside directorship at the end of 2017, I use year 2017 as the end year. This truncation can underestimate the actual outside director tenure a CEO holds.
} 
I report regression results in Table 12. The dependent variable is an indicator for CEOs' outside directorship turnovers within five years after the appointments. In Table 12 column (1), the positive coefficient of the negative ROA change dummy is statistically significant at the $5 \%$ level. In Table 12 column (5), the negative coefficient of the ROA change variable is statistically significant at the $10 \%$ level. Both coefficients indicate that changes for the worse operating performance of CEOs' own firms are associated with shorter outside directorship terms in the appointing firms. Again, this directorship turnover sensitivity to the performance of CEOs' own firms is not statistically different across CEOs' ownership, whether CEOs' own firms have blockholders, or the E index in CEO's firms, as shown in column (2)-(4) and (6)-(8).

These regression results suggest that when CEOs' outside directorships are associated with a decline in the operating performance of their own firms, their directorship terms are shorter than those of other CEOs. CEOs and/or the boards may decide to end the outside directorships, it is also possible that the appointing firms decide to terminate the directorships held by poor-performing CEOs. Even if the termination of directorships is an active decision made by CEOs and the boards of their own firms, since I do not find variations in the directorship turnover sensitivity to performance across CEOs' internal incentives or governance structure, it is not clear whether this is a voluntary decision or the outcome of boards' pressure.

When CEOs' directorships end, I find that relatively few appointing firms make a statement about their directors' resignation or their decision not to stand for re-election, and only sometimes they disclose specific reasons, such as time constraints imposed by the CEOs' primary executive jobs or personal health reasons.

Although I cannot elucidate the mechanism between CEOs' outside directorships, a worsening operating performance of their own firms, and the termination of CEOs' directorships, the evidence suggests that when CEOs need to spend more time on their own firms, the termination of their secondary responsibility from outside directorships is an option. 


\subsection{Beneficial Effect of Outside Directorships}

In this section, I investigate the possible benefits of CEOs' outside directorships and the sources of these benefits.

\subsection{Possible beneficial channels}

For the possible benefits from CEOs' outside directorships, I test four channels as described in the hypotheses section. I report results in Table 13. 11

[Insert Table 13 here]

One channel comprises CEOs' learning experiences. When the appointing firm is larger than a CEO's firm, the CEO is expected to build up more human capital. I use an indicator for appointments in which the appointing firm's market value (market share) is larger than the CEO firm's market value (market share).

Coefficients of the interaction term are positive and significant at the $5 \%$ level and $10 \%$ level in column (1) and (2), respectively. This indicates that CEOs' firms benefit from CEOs' board seats in larger firms. The coefficient 0.14 indicates that such CEOs' firms have an average 14 percentage points increase in ROA compared to other firms. The sum of the coefficient of the interaction term and the coefficient of treat dummy is also positive and significant at the $5 \%$ level in column (1) and (2), indicating an improvement in performance at CEOs' own firms. Considering that the average ROA of treated firms is $15 \%$, the magnitude of this coefficient seems too large. Since the IV estimate measures local average treatment effect and the instrument only applies to firms whose participation decision is affected by

\footnotetext{
${ }^{1}$ Both event study and performance analyses indicate that CEOs' first directorship appointments have positive effect on firm value and performance. In this section, I include all directorship appointments regardless of the number of directorships CEOs already hold. But the results are qualitatively similar when I restrict to CEOs who hold no more than one outside directorship.
} 
the distance to the appointing firms, without knowing the percentage of firms to which this IV applies, I am wary of making much of the magnitude here.

The second channel is information sharing between a CEO's firm and the appointing firm. If this channel is important, I would expect a larger increase in ROA when a CEO's firm and the appointing firm are related, for example, they are in the same industry or vertically related or informationally related. I use an indicator for each of these three relations as the conditioning variable.

The coefficients of the interaction term in columns (3)- (5) are not statistically different from zero. However, the sum of the coefficient of the interaction term and the coefficient of treat dummy is positive and significant at the $10 \%$ level in column (4). This result suggests that when a CEOs' firm and the appointing firm operate in vertically related industries, there is an improvement in the performance of CEO's own firm, though the improvement is not statistically different from that in cases where a CEO's firm and the appointing firm are not in vertically related industries..$^{2}$ This finding is a little weaker than the event study result, in which both CARs and the difference in CARs are positive and significant at the $10 \%$ level for vertically related cases. Regardless, however, the results suggest that information sharing is likely an important source of performance improvement among vertically related firms.

The third channel is the change in CEOs' network. The conditioning variables are the change in two centrality measures - degree and eigenvector at the appointment year. In column (6) and (7), the interaction terms do not have statistically significant coefficients. Thus, these results do not support this channel.

The fourth channel is a new business relation developed with the appointing firm. I define a new business relationship as occurring if the appointing firm and the CEO's firm do not have business transactions before an outside directorship appointment but start having transactions after. The conditioning variable I use to test this channel is an indicator for a new business relation. Since CEOs in control firms are not appointed to the pseudo appointing firms, this conditioning variable is zero for all control firms. I am aware that a control firm can still start a contract with the pseudo appointing firm without its CEO

\footnotetext{
${ }^{2}$ The coefficient of the interaction term is significant at the $1 \%$ level in column (4) if I do not cluster standard errors at the treated firm level. This underscores the importance of getting standard errors right by clustering.
} 
sitting on board of the appointing firm, and this business relation can be disclosed in the

annual reports. However, firms usually only disclose business partners with which they have a significant relationship with in $10-\mathrm{K}$ forms. For example, firms are required to disclose customers and suppliers that account for over 10\% of sales. In contrast, when CEOs are appointed to outside boards, the new contracts are usually small in size. As the contract size is mostly not disclosed, simply comparing treated firms and control firms without controlling for the contract size can lead to misleading inferences. Thus, as the conditioning variable is zero for all control firms and will be omitted in the regression, the interaction term measures the difference in ROA changes between treated firms that start a new business relation with the appointing firms and other treated firms rather than other control firms.

The results in column (8) suggest that a new business relation does not seem to benefit CEOs' firms more than other firms. The contract size may be often not substantial enough to have a detectable effect on performance.

Overall, the cross-sectional regression results provide support for CEOs' learning channel and information sharing channel. When CEOs are appointed as outside directors by larger firms and firms that operate in vertically related industries, their own firms have an improvement in operating performance during the subsequent three years.

\subsection{Further on CEOs' learning}

I argue that when CEOs are appointed as outside directors by larger firms, the improvement in operating performance is realized through CEOs' learning. In this section, I describe more evidence supporting this channel.

When serving on the boards of other firms, CEOs can learn both firm-specific knowledge of the appointing firms and general management knowledge. Since general management knowledge is more transferable across firms and industries, I expect that CEOs benefit more from the general knowledge gained at the appointing firms. General knowledge can be particularly beneficial to CEOs that have relatively low general managerial ability. I follow Custódio, Ferreira, and Matos (2013) and use an index that measures CEOs' general 
managerial ability based on their past work experiences. I obtain data on CEOs' work experiences from the BoardEx database.

This General Ability (GA) Index is constructed in Custódio et al. (2013) as following:

$$
G A \text { index }=0.268 X_{1}+0.312 X_{2}+0.309 X_{3}+0.218 X_{4}+0.153 X_{5}
$$

$X_{1}$ is the number of positions, such as production, finance, sales, and marketing, a CEO has held in the past. $X_{2}$ is the number of firms a CEO has worked for before. $X_{3}$ is the number of industries at the four-digit SIC level a CEO has worked in. $X_{4}$ is a dummy variable equal one if a CEO has held a CEO position at another firm. $X_{5}$ is a dummy variable equal one if a CEO has worked for a multi-division firm. A firm is defined as a multi-division firm if it has more than one business segment. I obtain the data of firms' business segments from the Compustat Segment database.

\section{[Insert Table 14 here]}

I standardize this index and define CEOs with a negative index as those with relatively less general managerial ability. I expect these CEOs to benefit more from the learning experience. The results in Table 14 confirm my prediction. The triple interaction term has a positive coefficient that is significant at the $1 \%$ level in column (2). This positive coefficient indicates that CEOs' own firms have a larger improvement in operating performance when CEOs have relatively less general managerial ability before joining the boards of larger firms. When firm size is measured by market value, this triple interaction term has a positive coefficient but it is not statistically significant, as shown in column (1).

If CEOs' learning is the source of benefit, then first-time learners, CEOs who do not have any previous experience of sitting on outside boards, should benefit more. Using the

start and end dates of each outside directorship tenure from the ISS database, I identify CEOs who have never been appointed as outside directors before they take a new outside directorship appointment.

[Insert Table 15 here] 
I interact treat dummy with the no experience dummy in the 2SLS regression, and report the results in Table 15. In column (1), the coefficient of the interaction term is positive and significant at the $5 \%$ level, and the sum of this coefficient and the coefficient of treat dummy is also positive and significant at the $5 \%$ level. This indicates that for CEOs without any previous experience as outside directors, their very first outside directorship appointments lead to an improvement in performance in their own firms, and this improvement is statistically larger than that in firms with experienced CEOs. In addition, the improvement in performance is stronger for cases when CEOs are appointed to larger firms compared to their own, as shown in column (2) and (3).

Together, these results on CEOs' general ability and previous outside board experiences provide more support for CEOs' learning channel.

\subsection{Marginal beneficial effect with multiple outside directorships}

The beneficial effect obtained through CEOs' learning suggests that on average benefits exceed costs to shareholders when CEOs are appointed to larger firms. However, when CEOs continue taking more directorships, the costs may offset benefits. To study how the beneficial effect varies with the number of directorships held by CEOs, I examine the marginal effect of their first, second, third, and fourth outside directorships, respectively when CEOs are appointed to larger firms.

\section{[Insert Table 16 here]}

I report the results in Table 16. The coefficient of the interaction term of treat dummy and the larger appointing firm dummy measures the marginal effect of CEOs' first directorships. The coefficients in both columns are positive and statistically significant, indicating an improvement in operating performance after CEOs' first directorships.

The marginal effect of CEOs' second outside directorships is the sum of coefficients of the interaction term of treat dummy, the larger appointing firm dummy and its interaction 
with the second directorship dummy. The sum is statistically significantly positive when I use market value as the proxy for firm size as shown in column (1), while the sum is not different from zero when I use market share as the proxy for firm size as shown in column (2). I find the same results for CEOs' third directorships. As for CEOs' fourth directorships, the marginal effect is not different from zero for both measures.

These results show a clear pattern of decreasing marginal beneficial effect of CEOs' outside directorships.

\subsection{Comovement between CEO's firm and appointing firm}

Along with CEOs' learning, the comovement between CEOs' own firms and appointing firms can potentially increase. This can be explained by the learning experiences that translate into CEOs' management style and similar ways of conducting business operations. The previous literature has documented comovement between firms sharing certain commonalities. Pirinsky and Wang (2006) find that stock returns of companies headquartered in the same geographic area exhibit a strong degree of comovement. Burt, Hrdlicka, and Harford (2018) find stock return comovemnet between firms sharing directors.

I study the comovement in both fundamentals measured by ROA and stock returns. I use two methods to measure the comovement. The first method measures the comovement of CEOs' firms by the time-series sensitivity of ROA/returns to those of the appointing firms.

For ROA, I run the following regression using quarterly ROA over the 10-year window around appointments. I exclude the appointment year, leaving five years before and after each appointment. If a quarter is outside a CEO's tenure or directorship tenure, that quarter is excluded. The coefficient $\beta_{1}$ measures the change in correlation in the covariance structure of fundamentals. Each firm is required to have at least 12 quarters of data before and after the appointment, respectively. As firms' fundamentals can be affected by

market-wide fluctuations and industry common shocks, such as shifts in demand and supply and technological changes, I control for market and industry conditions. Market ROA is the asset-weighted ROA for all the firms in Compustat, excluding CEOs' firms and appointing 
firms. Industry ROA is the asset-weighted ROA for all the firms in the same industry defined by Fama-French 48 industry classification, excluding CEOs' firms and appointing firms.

$R O A_{C E O, q}=\alpha+\beta_{1} R O A_{A p p t, q} \times$ Post $+\beta_{2} R O A_{A p p t, q}+\beta_{3}$ Post $+\beta_{4} R O A_{M k t, q}+\beta_{5} R O A_{\text {Ind,q }}+\epsilon_{q}$

I run the regression for each appointment separately, and obtain a coefficient $\beta_{1}$. The mean value of coefficients $\beta_{1}$ is not statistically different from zero, indicating no stronger comovement in fundamentals after appointments.

For stock returns, I use monthly stock returns from CRSP. To exclude systematic factors that can lead to a comovement, I use the Fama-French five-factor model as the baseline regression. Market return is the value-weighted return for all the firms in CRSP with a share code 10 or 11, excluding CEOs' firms and appointing firms. The other four factors are obtained from the Kenneth French data library. The remaining variables are the same as in the ROA regression. The mean value of coefficients $\beta_{1}$ is 0.03 and statistically significant at the $5 \%$ level.

$$
\begin{aligned}
\operatorname{Ret}_{C E O, m}=\alpha & +\beta_{1} \operatorname{Ret}_{A p p t, m} \times \text { Post }+\beta_{2} \operatorname{Ret}_{A p p t, m}+\beta_{3} \text { Post }_{+}+\beta_{4} \operatorname{Ret}_{M k t, m}+\beta_{5} S M B_{m} \\
& +\beta_{6} H M L_{m}+\beta_{7} R M W_{m}+\beta_{8} C M A_{m}+\epsilon_{m}
\end{aligned}
$$

As CEOs tend to sit on boards of nearby firms, and Pirinsky and Wang (2006) find comovement in stock returns of firms headquartered in the same area due to geographic segmentation, the comovement I find in stock returns may reflect geographic locations. To check this possibility, I add monthly return of each CEO firm's corresponding Metropolitan Statistical Area (MSA) index. MSA index return is the value-weighted return for all the firms headquartered in the same MSA in CRSP with a share code 10 or 11, excluding CEOs' firms and appointing firms. Using the 2000 zip code to MSA crosswalk file obtained from the Missouri Census Data Center, I define a firm's location as the Metropolitan Statistical Area of its headquarters. Nearly $95 \%$ of CEOs' firms are headquartered in metropolitan areas. Adding MSA index returns does not reduce the sample size by much. The mean value of the coefficients $\beta_{1}$ is no longer statistically different from zero. After controlling for geographic 
proximity of appointing firms, I do not find a statistically significant increase in comovement between CEOs' own firms and appointing firms.

The second method measures the explanatory power of one firm's fundamentals or returns to the other firm. This method has been used previously by others (for example, Hameed et al. 2015) to study the comovement between firms.

I first regress CEO firms' quarterly ROA on market ROA and industry ROA over the 10-year window around appointments. The definitions of market ROA and industry ROA are the same as in the previous method. For each appointment, I obtain R-squared $R_{1}^{2}$.

$$
R O A_{C E O, q}=\alpha+\beta_{1} R O A_{M k t, q}+\beta_{2} R O A_{I n d, q}+\epsilon_{q}
$$

Next, I add appointing firms' quarterly ROA in the regression, and obtain R-squared $R_{2}^{2}$.

$$
R O A_{C E O, q}=\alpha+\beta_{1} R O A_{M k t, q}+\beta_{2} R O A_{I n d, q}+\beta_{3} R O A_{A p p t, q}+\epsilon_{q}
$$

The additional explanatory power from adding the appointing firms' ROA out of the part

that cannot be explained by market and industry ROA is measured by $\left(R_{2}^{2}-R_{1}^{2}\right) /\left(1-R_{1}^{2}\right)$. I obtain this ratio for each appointment. The mean value of the ratios is positive but not statistically different from zero.

I use the same procedure and the Fama-French five-factor model to measure the comovement in stock returns. The mean value of the ratios is again positive but not statistically different from zero.

In sum, I do not find evidence that there is a stronger comovement in fundamentals or stock returns between CEOs' own firms and appointing firms after outside directorship appointments.

\subsection{Convergence in corporate policies}

Measures like ROA and stock return capture many firm-specific characteristics. Even if CEOs' firms and appointing firms have convergence in certain specific policies, it is possible that the convergence in these policies cannot be detected by general measures like ROA and 
stock return. In this subsection, I study whether CEOs' own firms start to adopt similar corporate policies as appointing firms after CEOs' outside directorship appointments.

I compare a set of policies for each paired set of CEO's firm and appointing firm before and after the appointment, and report mean values of levels, differences, and the change in differences for each variable in Table 17. For each appointment, I use a three-year window to compare policies in the pre- and post-appointment period. The appointment year is not included. If a year is outside a CEO's tenure or outside directorship tenure, that year is excluded. I report the mean value before and after the appointments for CEOs' own firms and the appointing firms, respectively. For each appointment, I calculate the change in CEO's own firm and the appointing firm, respectively. I also calculate the change in absolute value of the difference from before to after the appointments to see whether the distances in corporate policies change around appointments. I use one-sample t test to test whether these changes and differences are statistically different from zero.

\section{[Insert Table 17 here]}

As shown in Table 17, before directorship appointments, regarding financial policies, on average CEOs' own firms have lower leverage, lower dividend yield, greater R\&D expenses, and higher acquisition expenses compared to appointing firms.

In the post-appointment period, CEOs' own firms still have lower leverage ratio and dividend yield than appointing firms, and the differences in book leverage, market leverage, and dividend yield show little changes. The situation is a little different for investment. Both CEOs' own firms and appointing firms cut CAPX and R\&D expenses with similar magnitudes, and CEOs' own firms still have higher R\&D expenses in the post-appointment period. I use the absolute value of differences to measure distance regardless of the sign of differences. I find that the distances in CAPX and R\&D expenses are reduced after appointments. This finding indicates more similar investment policies after CEOs' directorship appointments. Since CEOs' own firms and appointing firms do not have statistically significant changes in acquisition expenses, I do not provide more details of acquisition expenses. 
To further investigate whether closer investment policies are driven by changes in CEOs' own firms, I check whether CEOs' own firms reduce (increase) investment when they have a higher (lower) level of investment compared to the appointing firms initially. When CEOs' own firms start at a higher (lower) level of CAPX, I find that $63 \%(42 \%)$ of them cut (increase) CAPX. When CEOs' firms change CAPX, in about $51 \%$ of cases CEOs' firms change by a larger amount compared to the appointing firms. This evidence suggests that CEOs' firms actively change CAPX to a level that is closer to that of the appointing firms. When CEOs' own firms start at a higher (lower) level of R\&D expenses, I find that $64 \%$ (25\%) of them cut (increase) R\&D. When CEOs' firms change R\&D, in about $71 \%$ of cases CEOs' firms change by a larger amount compared to the appointing firms. These evidence suggests that CEOs' firms actively change their investment to be closer to that in the appointing firms.

In terms of governance and compensation policies, as on average CEOs' own firms are smaller than appointing firms, it is expected that CEOs' own firms have smaller boards and lower CEOs' total compensation. Prior to appointments, CEOs' own firms have less independent boards and lower CEOs' beneficial ownership. While the distance in CEOs' beneficial ownership widens after appointments, the distance in board independence declines by a significant amount. In the post-appointment period, both CEOs' firms and appointing firms make their boards more independent. When CEOs' own firms have less (more) independent boards to start with, I find that $83 \%$ (32\%) of them increase (decrease) board independence. When CEOs' firms change board independence, in about $47 \%$ of cases CEOs' firms change by a larger percent compared to the appointing firms. This evidence suggests that CEOs' firms do not contribute more than appointing firms in the convergence of board independence.

While the differences in E index and CEOs' equity compensation percentage before appointments are not statistically different from zero, both become more convergent after appointments. While about $63 \%$ of CEOs' own firms have a higher E index to start with, only $7 \%$ of them decrease E index after appointments. Most CEOs' firms become more defensive in anti-takeover provisions regardless of the policy in appointing firms. As to CEOs' equity compensation percentage, both CEOs' firms and appointing firms link CEOs' compensation 
more to equity, and appointing firms increase by larger amounts. The appointment firms contribute more to the convergence.

Taken together, there is evidence of convergence in some corporate policies between CEOs' firms and appointing firms after CEOs' outside directorship appointments. In particular, CEOs' firms actively cut investment to levels closer to those of appointing firms.

The next question is whether the cut in investment benefits CEOs' firms through an improvement in investment efficiency. If this is the case, then investment policy would act as a specific channel through which CEOs' learning benefits their own firms.

I calculate the changes in investment-q sensitivity to study investment efficiency following McLean, Zhang, and Zhao (2012). The linear regression model is

$$
\frac{I_{i, t}}{A_{i, t-1}}=\alpha+\beta_{1} Q_{i, t-1} \times \text { Post }+\beta_{2} \frac{C F_{i, t-1}}{A_{i, t-1}} \times \text { Post }+\beta_{3} Q_{i, t-1}+\beta_{4} \frac{C F_{i, t-1}}{A_{i, t-1}}+\beta_{5} \text { Post }+\epsilon_{i, t}
$$

Investment (I) and cash flows (CF) are scaled by lagged book value of total assets (A). I use the sum of CAPX and R\&D expenses, CAPX, and R\&D expenses to measure investment. The coefficient $\beta_{1}$ captures the change in investment-Q sensitivity after appointments. If there is an improvement in investment efficiency, then the coefficient $\beta_{1}$ would be positive.

I run the regression for each appointment separately, and find that the mean value of coefficient $\beta_{1}$ is not statistically different from zero for all three measures of investment. 3 These results suggest that the reduction in investment initiated in CEOs' own firms is not associated with an improvement in investment efficiency after CEOs' outside directorship appointments.

\footnotetext{
${ }^{3}$ The results are qualitatively similar if I run the regression once in a pooled sample including all appointments.
} 


\subsection{Conclusions}

CEOs' directorships in other firms have raised concerns that these extra responsibilities may hurt CEOs' own firms. Overall, I find little evidence supporting these concerns. I do not find a decline in the performance of the CEOs' own firms, nor do stock prices react negatively to the announcements of CEOs' outside directorship appointments. Instead, my results support the view that CEOs' outside directorships can benefit their own firms through CEOs' learning and information sharing. When CEOs are appointed to larger firms and firms that operate in vertically related industries, CEOs' own firms exhibit an improvement in operating performance in the subsequent three years. I find that CEOs' own firms benefit most from their first directorships. The marginal beneficial effect declines when CEOs continue taking more directorships. However, even when CEOs hold multiple directorships, I do not find a decline in operating performance at the CEOs' own firms. 


\section{Appendix}

\section{Definition of variables}

\begin{tabular}{|c|c|c|}
\hline Variable & Definition & Data source \\
\hline \multicolumn{2}{|l|}{ Firm characteristics } & \\
\hline Assets & Book value of assets & Compustat \\
\hline Market value (of equity) & $\begin{array}{l}\text { Stock price at the end of a fiscal year multiplied by } \\
\text { number of common shares outstanding }\end{array}$ & Compustat \\
\hline Market-to-book ratio & (Assets - book equity + market value of equity)/assets & Compustat \\
\hline Market share & Percentage of sales in the same SIC2 industry & Compustat \\
\hline $\begin{array}{l}(\mathrm{CAPX}+\mathrm{R} \& \mathrm{D}) / \\
\operatorname{lag}(\text { Assets })\end{array}$ & $\begin{array}{l}\text { (Capital expenditures }+\mathrm{R} \& D \text { expenses)/lagged assets, } \\
\text { R\&D expenses set to } 0 \text { if missing }\end{array}$ & Compustat \\
\hline Sales growth rate & Percent change in sales & Compustat \\
\hline Return on assets (ROA) & Operating income before depreciation/lagged assets & Compustat \\
\hline Return on sales (ROS) & Net income/sales & Compustat \\
\hline Stock return & Buy-and-hold return over the fiscal year & CRSP \\
\hline Institutional ownership & Percent of common shares owned by institutions & Thomson $13 \mathrm{~F}$ \\
\hline Blockholder presence & $\begin{array}{l}\text { Presence of at least one institutional shareholder that } \\
\text { holds more than } 5 \% \text { of common shares }\end{array}$ & Thomson $13 \mathrm{~F}$ \\
\hline $\begin{array}{l}\text { Per capita personal } \\
\text { income }\end{array}$ & $\begin{array}{l}\text { County-level data based on firm's headquarters (Map } \\
\text { firm's zip code to county using } 2010 \text { correspondence file) }\end{array}$ & $\begin{array}{l}\text { Bureau of } \\
\text { Economic } \\
\text { Analysis }\end{array}$ \\
\hline Unemployment rate & $\begin{array}{l}\text { County-level data based on firm's headquarters (Map } \\
\text { firm's zip code to county using } 2010 \text { correspondence file) }\end{array}$ & $\begin{array}{l}\text { Bureau of } \\
\text { Labor } \\
\text { Statistics }\end{array}$ \\
\hline \multicolumn{2}{|c|}{ Governance and CEO characteristics } & \\
\hline Board size & Number of directors on the board & ISS \\
\hline $\begin{array}{l}\text { Board independence } \\
\text { ratio }\end{array}$ & Number of independent directors/board size & ISS \\
\hline E index & E index defined in Bebchuk et al. (2008) & ISS \\
\hline CEO's tenure & Number of years in CEO's position & ISS \\
\hline CEO's age & Age & ISS \\
\hline $\begin{array}{l}\text { CEO's total } \\
\text { compensation }\end{array}$ & $\begin{array}{l}\text { CEO's total compensation including value of stocks and } \\
\text { option grants }\end{array}$ & Execucomp \\
\hline $\begin{array}{l}\text { CEO's equity-based } \\
\text { compensation percent }\end{array}$ & $\begin{array}{l}\text { Percent of total compensation that comes from stocks and } \\
\text { options }\end{array}$ & Execucomp \\
\hline
\end{tabular}




\begin{tabular}{|c|c|c|}
\hline $\begin{array}{l}\text { CEO's beneficial } \\
\text { ownership }\end{array}$ & Percent of shares held by CEO & Execucomp \\
\hline Degree centrality & $\begin{array}{l}\text { Number of direct connections scaled by the total number } \\
\text { of individuals in the network (Compute using Python } \\
\text { package Centrality) }\end{array}$ & BoardEx \\
\hline Eigenvector centrality & $\begin{array}{l}\text { Relative score assigned based on the concept that } \\
\text { connections to individuals with high scores contribute } \\
\text { more to the network (Compute using Python package } \\
\text { Centrality) }\end{array}$ & BoardEx \\
\hline $\begin{array}{l}\text { General ability (GA) } \\
\text { index }\end{array}$ & $\begin{array}{l}0.268 X_{1}+0.312 X_{2}+0.309 X_{3}+0.218 X_{4}+0.153 X_{5}, \\
\text { where } X_{1} \text { is the number of positions, such as production, } \\
\text { finance, sales, and marketing, a CEO has held in the past. } \\
X_{2} \text { is the number of firms a CEO has worked for. } X_{3} \text { is } \\
\text { the number of industries at the four-digit SIC level a CEO } \\
\text { has worked in. } X_{4} \text { is a dummy variable equal one if a } \\
\text { CEO has held a CEO position at another firm. } X_{5} \text { is a } \\
\text { dummy variable equal one if a CEO has worked for a } \\
\text { multi-division firm. A firm is defined as a multi-division } \\
\text { firm if this firm has more than one business segment. The } \\
\text { data of firms' business segments are obtained from the } \\
\text { Compustat Segment database. }\end{array}$ & $\begin{array}{l}\text { BoardEx, } \\
\text { Compustat }\end{array}$ \\
\hline \multicolumn{2}{|c|}{ Relationship between CEO's firm and appointing firm } & \multirow[b]{2}{*}{$\begin{array}{l}\text { Hoberg-Phillips } \\
\text { data library }\end{array}$} \\
\hline Same industry & Same industry based on Hoberg-Phillips classifications & \\
\hline Vertically related & $\begin{array}{l}\text { I follow the procedure in Becker and Thomas }(2011) \text { and } \\
\text { Ahern and Harford }(2014) \text { to calculate the } \\
\text { customer-supplier trade percentage between two } \\
\text { industries. When two firms operate in two industries that } \\
\text { have a customer-supplier relationship and either customer } \\
\text { percentage or supplier percentage exceeds } 1 \%, \text { I define } \\
\text { these two firms as vertically related. }\end{array}$ & $\begin{array}{l}\text { Bureau of } \\
\text { Economic } \\
\text { Analysis } \\
\text { Input-Output } \\
\text { table }\end{array}$ \\
\hline
\end{tabular}




\begin{tabular}{|c|c|c|}
\hline Informationally related & $\begin{array}{l}\text { Following Hameed et al. }(2015) \text {, for each CEO } \\
\text { firm-appointing firm pair, I first regress the quarterly ROA } \\
\text { of CEO's firm over a five-year window on market ROA } \\
\text { (the value-weighted average ROA of all firms, excluding } \\
\text { CEO's firm and appointing firm) and industry ROA (the } \\
\text { value-weighted average ROA of all firms in the same } \\
\text { Fama-French } 48 \text { industry, excluding CEO's firm and } \\
\text { appointing firm), requiring at least } 12 \text { non-missing } \\
\text { quarterly observations, and obtain } R_{1}^{2} \text {. Next, I add the } \\
\text { ROA of the appointing firm to the regression and obtain } \\
R_{2}^{2} \text {. The contribution of the additional explanatory power } \\
\text { is defined as }\left(R_{2}^{2}-R_{1}^{2}\right) /\left(1-R_{1}^{2}\right) \text {. This number is the } \\
\text { information correlation between two firms. I define two } \\
\text { firms informationally related if their information } \\
\text { correlation is above the sample median. }\end{array}$ & Compustat \\
\hline $\begin{array}{l}\text { New business } \\
\text { relationship }\end{array}$ & $\begin{array}{l}\text { A new business relationship with the appointing firm } \\
\text { starts at CEO's outside directorship appointment year or } \\
\text { in the following three years }\end{array}$ & $\begin{array}{l}\text { Appointing } \\
\text { firms' proxy } \\
\text { statements, } \\
\text { SEC EDGAR }\end{array}$ \\
\hline
\end{tabular}




\section{Bibliography}

Adams, Renee B, and Daniel Ferreira, 2007, A theory of friendly boards, The journal of finance $62,217-250$.

Adams, Renée B, and Daniel Ferreira, 2008, Do directors perform for pay?, Journal of Accounting and Economics 46, 154-171.

Adams, Renée B, Benjamin E Hermalin, and Michael S Weisbach, 2010, The role of boards of directors in corporate governance: A conceptual framework and survey, Journal of economic literature 48, 58-107.

Aggarwal, Reena, Isil Erel, René Stulz, and Rohan Williamson, 2008, Differences in governance practices between us and foreign firms: Measurement, causes, and consequences, The Review of Financial Studies 22, 3131-3169.

Agrawal, Anup, and Sahiba Chadha, 2005, Corporate governance and accounting scandals, The Journal of Law and Economics 48, 371-406.

Agrawal, Anup, and Charles R Knoeber, 2001, Do some outside directors play a political role?, The Journal of Law and Economics 44, 179-198.

Ahern, Kenneth R, and Jarrad Harford, 2014, The importance of industry links in merger waves, The Journal of Finance 69, 527-576.

Angrist, Joshua D, and Jörn-Steffen Pischke, 2008, Mostly harmless econometrics: An empiricist's companion (Princeton university press).

Barber, Brad M, and John D Lyon, 1996, Detecting abnormal operating performance: The empirical power and specification of test statistics, Journal of financial Economics 41, 359-399.

Bebchuk, Lucian, Alma Cohen, and Allen Ferrell, 2008, What matters in corporate governance?, The Review of financial studies 22, 783-827.

Becker, Mary J, and Shawn Thomas, 2011, Changes in concentration across vertically related industries .

Bertrand, Marianne, and Antoinette Schoar, 2003, Managing with style: The effect of managers on firm policies, The Quarterly journal of economics 118, 1169-1208.

Bizjak, John, Michael Lemmon, and Ryan Whitby, 2009, Option backdating and board interlocks, The Review of Financial Studies 22, 4821-4847. 
Booth, James R, and Daniel N Deli, 1996, Factors affecting the number of outside directorships held by ceos, Journal of Financial Economics 40, 81-104.

Brickley, James A, James S Linck, and Jeffrey L Coles, 1999, What happens to ceos after they retire? new evidence on career concerns, horizon problems, and ceo incentives, Journal of Financial Economics 52, 341-377.

Burt, Aaron, Christopher M Hrdlicka, and Jarrad Harford, 2018, How much do directors influence firm value?, Forthcoming in: Review of Financial Studies .

Byrd, John W, and Kent A Hickman, 1992, Do outside directors monitor managers?: Evidence from tender offer bids, Journal of financial economics 32, 195-221.

Cai, Jie, Jacqueline L Garner, and Ralph A Walkling, 2009, Electing directors, The Journal of Finance 64, 2389-2421.

Chhaochharia, Vidhi, and Yaniv Grinstein, 2007, Corporate governance and firm value: The impact of the 2002 governance rules, the Journal of Finance 62, 1789-1825.

Cohen, Lauren, Andrea Frazzini, and Christopher Malloy, 2008, The small world of investing: Board connections and mutual fund returns, Journal of Political Economy 116, 951-979.

Cohen, Lauren, Andrea Frazzini, and Christopher Malloy, 2010, Sell-side school ties, The Journal of Finance 65, 1409-1437.

Coles, Jeffrey L, Naveen D Daniel, and Lalitha Naveen, 2014, Co-opted boards, The Review of Financial Studies 27, 1751-1796.

Conyon, Martin J, and Laura E Read, 2006, A model of the supply of executives for outside directorships, Journal of Corporate Finance 12, 645-659.

Core, John E, Robert W Holthausen, and David F Larcker, 1999, Corporate governance, chief executive officer compensation, and firm performance, Journal of financial economics 51, 371-406.

Cotter, James F, Anil Shivdasani, and Marc Zenner, 1997, Do independent directors enhance target shareholder wealth during tender offers?, Journal of financial economics $43,195-218$.

Custódio, Cláudia, Miguel A Ferreira, and Pedro Matos, 2013, Generalists versus specialists: Lifetime work experience and chief executive officer pay, Journal of Financial Economics 108, 471-492.

Dahya, Jay, Orlin Dimitrov, and John J McConnell, 2008, Dominant shareholders, corporate boards, and corporate value: A cross-country analysis, Journal of Financial Economics 87, 73-100. 
Dass, Nishant, Omesh Kini, Vikram Nanda, Bunyamin Onal, and Jun Wang, 2014, Board expertise:: do directors from related industries help bridge the information gap?, Review of Financial Studies 27, 1533-1592.

Duchin, Ran, John G Matsusaka, and Oguzhan Ozbas, 2010, When are outside directors effective?, Journal of financial economics 96, 195-214.

Edmans, Alex, 2014, Blockholders and corporate governance, Annu. Rev. Financ. Econ. 6, $23-50$.

El-Khatib, Rwan, Kathy Fogel, and Tomas Jandik, 2015, Ceo network centrality and merger performance, Journal of Financial Economics 116, 349-382.

Ellis, Jesse A, C Edward Fee, and Shawn Thomas, 2018, Playing favorites? industry expert directors in diversified firms, Journal of Financial and Quantitative Analysis 53, 1679-1714.

Estélyi, Kristína Sághy, and Tahir M Nisar, 2016, Diverse boards: Why do firms get foreign nationals on their boards?, Journal of Corporate Finance 39, 174-192.

Fahlenbrach, Rüdiger, Angie Low, and René M Stulz, 2010, Why do firms appoint ceos as outside directors?, Journal of Financial Economics 97, 12-32.

Fahlenbrach, Rüdiger, Angie Low, and René M Stulz, 2017, Do independent director departures predict future bad events?, The Review of Financial Studies 30, 2313-2358.

Falato, Antonio, Dalida Kadyrzhanova, and Ugur Lel, 2014, Distracted directors: Does board busyness hurt shareholder value?, Journal of Financial Economics 113, 404-426.

Faleye, Olubunmi, Vikas Mehrotra, and Randall Morck, 2006, When labor has a voice in corporate governance, Journal of financial and quantitative analysis 41, 489-510.

Fauver, Larry, and Michael E Fuerst, 2006, Does good corporate governance include employee representation? evidence from german corporate boards, Journal of financial economics $82,673-710$.

Ferris, Stephen P, Murali Jagannathan, and Adam C Pritchard, 2003, Too busy to mind the business? monitoring by directors with multiple board appointments, The Journal of finance 58, 1087-1111.

Fich, Eliezer M, 2005, Are some outside directors better than others? evidence from director appointments by fortune 1000 firms, The Journal of Business 78, 1943-1972.

Fich, Eliezer M, and Anil Shivdasani, 2006, Are busy boards effective monitors?, The Journal of finance 61, 689-724.

Fich, Eliezer M, and Lawrence J White, 2005, Why do ceos reciprocally sit on each other's boards?, Journal of Corporate Finance 11, 175-195. 
Field, Laura, Michelle Lowry, and Anahit Mkrtchyan, 2013, Are busy boards detrimental?, Journal of Financial Economics 109, 63-82.

Fracassi, Cesare, 2016, Corporate finance policies and social networks, Management Science $63,2420-2438$.

Fracassi, Cesare, and Geoffrey Tate, 2012, External networking and internal firm governance, the Journal of finance 67, 153-194.

Goldman, Eitan, Jörg Rocholl, and Jongil So, 2013, Politically connected boards of directors and the allocation of procurement contracts, Review of Finance 17, 1617-1648.

Gormley, Todd A, and David A Matsa, 2013, Common errors: How to (and not to) control for unobserved heterogeneity, The Review of Financial Studies 27, 617-661.

Gorton, Gary, and Frank A Schmid, 2004, Capital, labor, and the firm: A study of german codetermination, Journal of the European Economic Association 2, 863-905.

Güner, A Burak, Ulrike Malmendier, and Geoffrey Tate, 2008, Financial expertise of directors, Journal of financial Economics 88, 323-354.

Guo, Lixiong, and Ronald W Masulis, 2015, Board structure and monitoring: New evidence from ceo turnovers, The Review of Financial Studies 28, 2770-2811.

Hallock, Kevin F, 1997, Reciprocally interlocking boards of directors and executive compensation, Journal of financial and Quantitative Analysis 32, 331-344.

Hameed, Allaudeen, Randall Morck, Jianfeng Shen, and Bernard Yeung, 2015, Information, analysts, and stock return comovement, The Review of Financial Studies 28, 3153-3187.

Harris, Milton, and Artur Raviv, 2006, A theory of board control and size, The Review of Financial Studies 21, 1797-1832.

Hauser, Roie, 2018, Busy directors and firm performance: Evidence from mergers, Journal of Financial Economics 128, 16-37.

Heider, Florian, and Alexander Ljungqvist, 2015, As certain as debt and taxes: Estimating the tax sensitivity of leverage from state tax changes, Journal of Financial Economics 118, $684-712$.

Hoberg, Gerard, and Gordon Phillips, 2010, Product market synergies and competition in mergers and acquisitions: A text-based analysis, The Review of Financial Studies 23, $3773-3811$.

Hoberg, Gerard, and Gordon Phillips, 2016, Text-based network industries and endogenous product differentiation, Journal of Political Economy 124, 1423-1465. 
Hwang, Byoung-Hyoun, and Seoyoung Kim, 2009, It pays to have friends, Journal of financial economics 93, 138-158.

Iliev, Peter, and Lukas Roth, 2018, Learning from directors' foreign board experiences, Journal of Corporate Finance 51, 1-19.

Imai, Kosuke, and In Song Kim, 2013, On the use of linear fixed effects regression estimators for causal inference, Unpublished Manuscript .

Jensen, Michael C, and William H Meckling, 1976, Theory of the firm: Managerial behavior, agency costs and ownership structure, Journal of financial economics 3, 305-360.

Jenter, Dirk, and Katharina A Lewellen, 2017, Performance-induced ceo turnover .

Kang, Shinwoo, E Han Kim, and Yao Lu, 2017, Does independent directors' ceo experience matter?, Review of Finance 22, 905-949.

Knyazeva, Anzhela, Diana Knyazeva, and Ronald W Masulis, 2013, The supply of corporate directors and board independence, The Review of Financial Studies 26, 1561-1605.

Larcker, David F, Eric C So, and Charles CY Wang, 2013, Boardroom centrality and firm performance, Journal of Accounting and Economics 55, 225-250.

Lee, Jongsub, Kwang J Lee, and Nandu J Nagarajan, 2014, Birds of a feather: Value implications of political alignment between top management and directors, Journal of Financial Economics 112, 232-250.

Linck, James S, Jeffry M Netter, and Tina Yang, 2008, The determinants of board structure, Journal of financial economics 87, 308-328.

Ljungqvist, Alexander, and Konrad Raff, 2017, Busy directors: strategic interaction and monitoring synergies, Technical report, National Bureau of Economic Research.

Loderer, Claudio, and Urs Peyer, 2002, Board overlap, seat accumulation and share prices, European Financial Management 8, 165-192.

Masulis, Ronald W, and Shawn Mobbs, 2014, Independent director incentives: Where do talented directors spend their limited time and energy?, Journal of Financial Economics 111, 406-429.

Masulis, Ronald W, Cong Wang, and Fei Xie, 2012, Globalizing the boardroom - the effects of foreign directors on corporate governance and firm performance, Journal of Accounting and Economics 53, 527-554.

Masulis, Ronald W, and Emma Jincheng Zhang, 2018, How valuable are independent directors? evidence from external distractions, Journal of Financial Economics . 
McLean, R David, Tianyu Zhang, and Mengxin Zhao, 2012, Why does the law matter? investor protection and its effects on investment, finance, and growth, The Journal of Finance 67, 313-350.

Nguyen, Bang Dang, 2012, Does the rolodex matter? corporate elite's small world and the effectiveness of boards of directors, Management Science 58, 236-252.

Nguyen, Bang Dang, and Kasper Meisner Nielsen, 2010, The value of independent directors: Evidence from sudden deaths, Journal of financial economics 98, 550-567.

Perry, Tod, and Urs Peyer, 2005, Board seat accumulation by executives: A shareholder's perspective, The Journal of Finance 60, 2083-2123.

Pirinsky, Christo, and Qinghai Wang, 2006, Does corporate headquarters location matter for stock returns?, The Journal of Finance 61, 1991-2015.

Raheja, Charu G, 2005, Determinants of board size and composition: A theory of corporate boards, Journal of financial and quantitative analysis 40, 283-306.

Rosenstein, Stuart, and Jeffrey G Wyatt, 1994, Shareholder wealth effects when an officer of one corporation joins the board of directors of another, Managerial and Decision Economics $15,317-327$.

Vancil, Richard F, 1987, Passing the baton: Managing the process of CEO succession (Harvard Business School Pr).

Wang, Cong, Fei Xie, and Min Zhu, 2015, Industry expertise of independent directors and board monitoring, Journal of Financial and Quantitative Analysis 50, 929-962.

Wooldridge, Jeffrey M, 2010, Econometric analysis of cross section and panel data (MIT press).

Yermack, David, 2004, Remuneration, retention, and reputation incentives for outside directors, The Journal of Finance 59, 2281-2308. 
Figure 1. Level of ROA around year $\mathrm{t}$

This figure shows mean and median ROA from three years before to three years after for each firm at year t. Sample of CEOs' outside director appointments is from 1999 to 2012. Treated firms are firms whose CEO accepts a new outside directorship in year t. Control firms are firms whose CEO does not have an outside director appointment in the entire sample period.

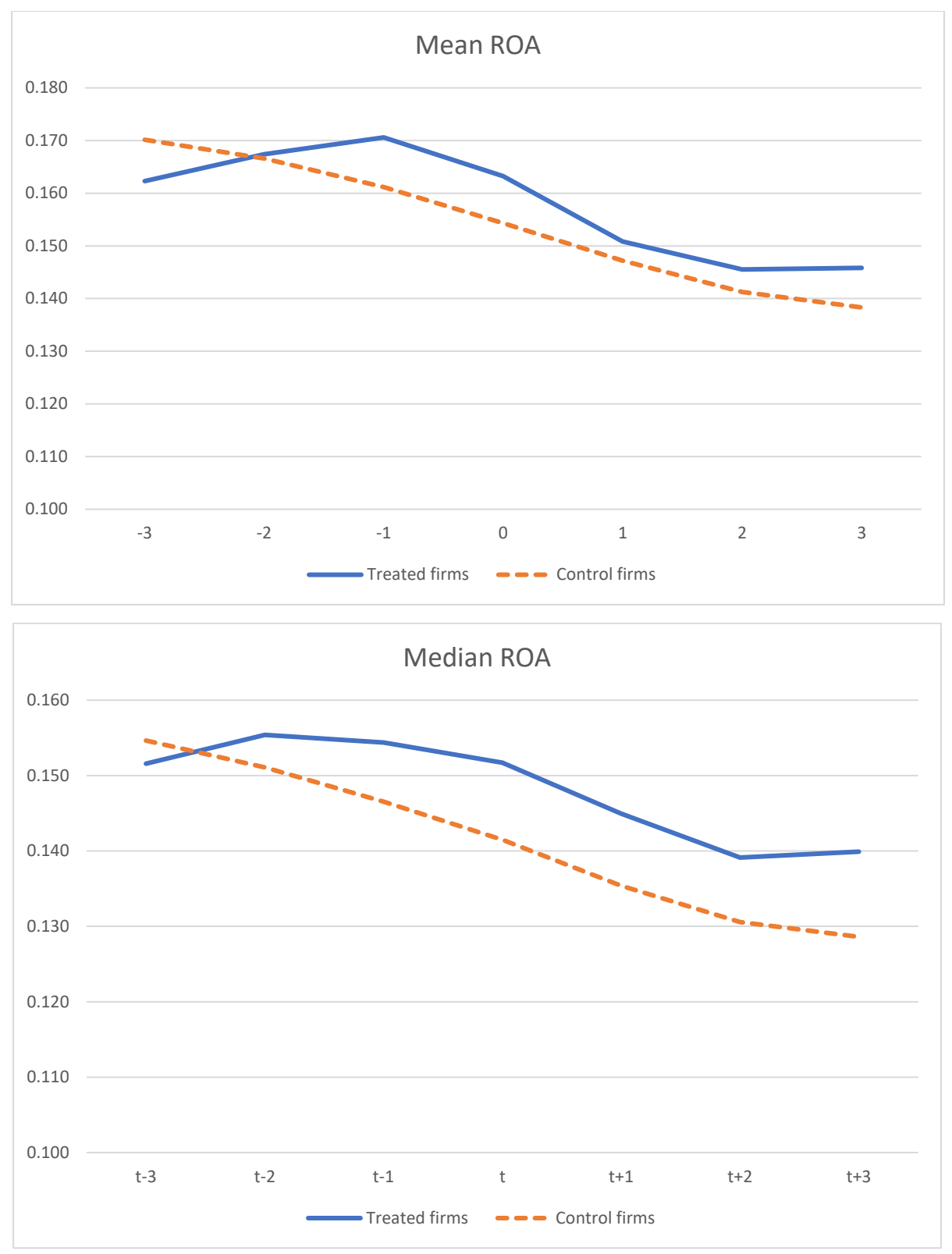


Figure 2. Distribution of distance to appointing firm's headquarters

This figure shows the distance between a treated/control firm's headquarters and the appointing firm's headquarters in miles. For each control firm, the pseudo appointing firm is the appointing firm of the treated firm to which this control firm is matched. Sample of CEOs' outside director appointments is from 1999 to 2012. Treated firms are firms whose CEO accepts a new outside directorship in year t. Control firms are firms whose CEO does not have an outside director appointment in the entire sample period.

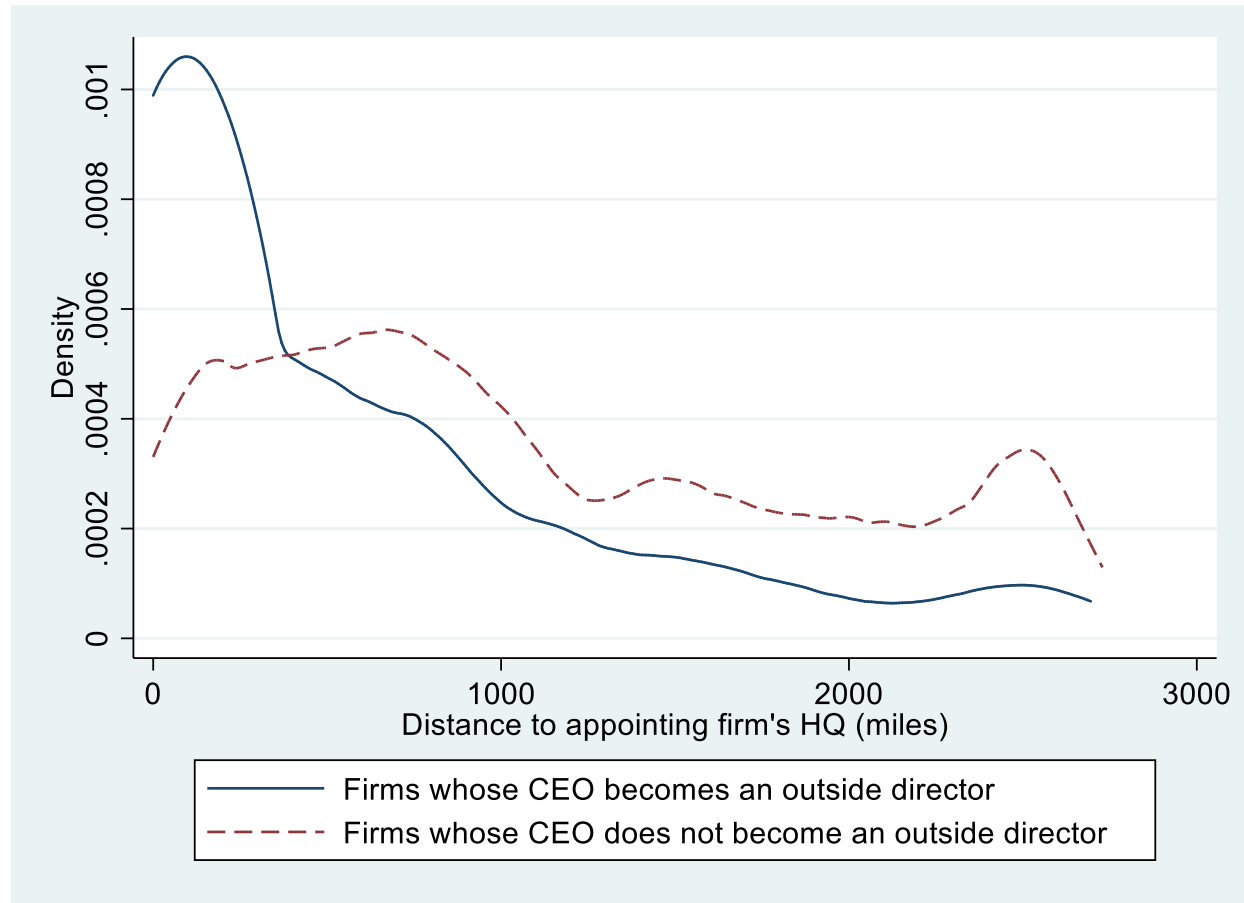


Table 1. Summary statistics

This table displays summary statistics of number of CEOs' outside directorships. Sample is from 1999 to 2012.

Panel A. Frequency distribution of number of outside directorships CEOs already hold before accepting a new appointment

\begin{tabular}{ccc}
\hline \hline $\begin{array}{c}\text { Number of CEOs' existing outside directorships } \\
\text { before accepting a new appointment }\end{array}$ & Frequency & Percent \\
\hline 0 & 389 & $48 \%$ \\
1 & 257 & $32 \%$ \\
2 & 118 & $15 \%$ \\
3 & 32 & $4 \%$ \\
4 & 8 & $1 \%$ \\
& & \\
\hline
\end{tabular}

Panel B. Number of CEOs' outside directorship appointments by year

\begin{tabular}{cccc}
\hline \hline Year & $\begin{array}{c}\text { \# CEOs' outside } \\
\text { directorship appointments }\end{array}$ & $\begin{array}{c}\text { \# Outside directorship } \\
\text { appointments }\end{array}$ & Percent \\
\hline & 82 & 1268 & $6 \%$ \\
2009 & 79 & 1335 & $6 \%$ \\
2001 & 91 & 1442 & $6 \%$ \\
2002 & 61 & 1319 & $5 \%$ \\
2003 & 54 & 1660 & $3 \%$ \\
2004 & 56 & 1604 & $3 \%$ \\
2005 & 61 & 1464 & $4 \%$ \\
2006 & 51 & 1214 & $4 \%$ \\
2007 & 58 & 1273 & $5 \%$ \\
2009 & 60 & 1091 & $5 \%$ \\
2010 & 31 & 882 & $4 \%$ \\
2011 & 40 & 822 & $5 \%$ \\
2012 & 45 & 901 & $5 \%$ \\
Total & 35 & 876 & $4 \%$ \\
\hline
\end{tabular}


Panel C. Number of firms whose CEO holds outside directorship(s) by year

\begin{tabular}{cccc|ccc}
\hline \hline Year & $\begin{array}{c}\text { \# S\&P 1500 } \\
\text { firms whose } \\
\text { CEO holds } \\
\text { outside }\end{array}$ & $\begin{array}{c}\text { \# S\&P } \\
1500 \\
\text { firms in } \\
\text { directorship(s) }\end{array}$ & Percent & $\begin{array}{c}\text { \# S\&P 500 } \\
\text { firms whose } \\
\text { CEO holds } \\
\text { outside }\end{array}$ & $\begin{array}{c}\text { \# S\&P } \\
500 \text { firms } \\
\text { in sample }\end{array}$ & Percent \\
directorship(s) & & \\
1999 & 333 & 1104 & $30 \%$ & 170 & 413 & $41 \%$ \\
2000 & 363 & 1266 & $29 \%$ & 191 & 423 & $45 \%$ \\
2001 & 395 & 1337 & $30 \%$ & 208 & 448 & $46 \%$ \\
2002 & 380 & 1362 & $28 \%$ & 211 & 458 & $46 \%$ \\
2003 & 408 & 1418 & $29 \%$ & 212 & 459 & $46 \%$ \\
2004 & 403 & 1426 & $28 \%$ & 200 & 452 & $44 \%$ \\
2005 & 426 & 1409 & $30 \%$ & 204 & 449 & $45 \%$ \\
2006 & 410 & 1397 & $29 \%$ & 200 & 448 & $45 \%$ \\
2007 & 405 & 1428 & $28 \%$ & 190 & 453 & $42 \%$ \\
2008 & 415 & 1479 & $28 \%$ & 193 & 467 & $41 \%$ \\
2009 & 373 & 1502 & $25 \%$ & 172 & 473 & $36 \%$ \\
2010 & 389 & 1475 & $26 \%$ & 179 & 476 & $38 \%$ \\
2011 & 399 & 1446 & $28 \%$ & 182 & 465 & $39 \%$ \\
2012 & 405 & 1441 & $28 \%$ & 190 & 463 & $41 \%$ \\
Total & 5504 & 19490 & $28 \%$ & 2702 & 6347 & $43 \%$ \\
\hline
\end{tabular}


Table 2. Characteristics of CEOs' firms and appointing firms

Panel A displays the comparison of mean and median values between firms whose CEO accepts a new outside directorship in a year and firms whose CEO does not have an outside directorship appointment in the entire sample period. Sample is from year 1999 to 2012. All variables are defined in Appendix. Two-sample t tests (Wilcoxon-Mann-Whitney tests) are conducted to test whether the means (medians) of variables are significantly different from two groups. Statistical significance at $1 \%, 5 \%$, and $10 \%$ level is indicated by $* * *, * *$, and $*$, respectively. Panel B displays the percentage of appointing firm - CEO's firm pairs that have certain relationships in each row. Panel C displays the summary statistics of change in CEOs' network centrality at the appointment year.

Panel A. Firm and CEO characteristics

\begin{tabular}{|c|c|c|c|c|}
\hline & \multicolumn{2}{|c|}{$\begin{array}{l}\text { Firms whose CEO } \\
\text { accepts a new outside } \\
\text { directorship } \\
\text { appointment } \\
(\mathrm{N}=804)\end{array}$} & \multicolumn{2}{|c|}{$\begin{array}{c}\text { Firms whose CEO does } \\
\text { not have an outside } \\
\text { directorship } \\
\text { appointment } \\
(\mathrm{N}=16,101)\end{array}$} \\
\hline & Mean & Median & Mean & Median \\
\hline Total assets $(\$ \mathrm{~m})$ & 16617 & 3928 & $11744^{* * *}$ & $2030^{* * *}$ \\
\hline Firm age & 34 & 36 & $27 * * *$ & $22^{* * *}$ \\
\hline Market-to-book ratio & 1.89 & 1.50 & 1.85 & $1.45^{* *}$ \\
\hline$(\mathrm{CAPX}+\mathrm{R} \& \mathrm{D}) / \operatorname{lag}(\mathrm{AT})$ & 0.08 & 0.06 & 0.08 & 0.06 \\
\hline Sales growth rate & 0.10 & 0.07 & 0.10 & 0.07 \\
\hline $\mathrm{ROA}$ & 0.16 & 0.15 & $0.15^{* * *}$ & $0.14^{* * *}$ \\
\hline Stock return & 0.09 & 0.07 & 0.11 & 0.09 \\
\hline Institutional ownership & 0.73 & 0.75 & 0.74 & 0.77 \\
\hline Board size & 11 & 10 & $10^{* *}$ & $9^{* * *}$ \\
\hline Board independence ratio & 0.47 & 0.45 & 0.47 & 0.45 \\
\hline CEO's tenure & 6 & 5 & $9^{* * *}$ & $7^{* * *}$ \\
\hline CEO's age & 57 & 57 & 57 & 57 \\
\hline CEO's compensation ( $\$$ ths $)$ & $\$ 7,085$ & $\$ 5,180$ & $\$ 5,282^{* * *}$ & $\$ 3,240^{* * *}$ \\
\hline CEO's equity compensation (\%) & 66.64 & 72.69 & $60.74^{* * *}$ & $68.18^{* * *}$ \\
\hline CEO's beneficial ownership (\%) & 1.29 & 0.59 & $3.65^{* * *}$ & $0.99^{* * *}$ \\
\hline
\end{tabular}


Panel B. Relationship between CEOs' own firms and appointing firms

CEOs' own firms and Appointing firms $\quad$ Percent

Market share appointing firm > CEO's firm $\quad 56 \%$

Market value appointing firm > CEO's firm $\quad 53 \%$

Firm age appointing firm > CEO's firm $\quad 45 \%$

Same two-digit SIC industry $\quad 14 \%$

Same four-digit SIC industry $3 \%$

Same Hoberg-Phillips industry $\quad 7 \%$

Vertically related $10 \%$

Informationally related $\quad 30 \%$

Have business transaction in any year between t-3 and $t+3 \quad 12 \%$

Already have business transaction before appointment $2 \%$

Start new business transaction after appointment or at the same year $\quad 11 \%$

Panel C. Change in CEOs' network centrality at the appointment year

\begin{tabular}{lcccc}
\hline \hline & Mean $(\mathrm{p}$ value $)$ & Median $(\mathrm{p}$ value $)$ & Min & Max \\
\cline { 2 - 5 }$\Delta$ Degree & $0.0185^{* * *}(<0.001)$ & $0.0106^{* * *}(<0.001)$ & -0.007 & 0.182 \\
$\Delta$ Eigenvector & $0.0057^{* * *}(0.0021)$ & $0.0002^{* * *}(<0.001)$ & -0.043 & 0.678 \\
\hline
\end{tabular}


Table 3. Determinants of CEOs accepting an outside directorship

This table displays logit regression results. Sample is from year 1999 to 2012. Dependent variable is a dummy variable equal to 1 if in that year a firm's CEO accepts an outside directorship in another firm. All independent variables are for CEOs' own firms and defined in Appendix. All independent variables are winsorized at $1 \%$ and $99 \%$. Standard errors are corrected for heteroscedasticity and clustered at firm level. Statistical significance at 1\%,5\%, and $10 \%$ level is indicated by ***,**, and ${ }^{*}$, respectively.

\begin{tabular}{|c|c|c|}
\hline & $(1)$ & $(2)$ \\
\hline $\operatorname{Ln}($ Assets $)$ & $\begin{array}{c}0.253^{* * *} \\
(0.0275)\end{array}$ & $\begin{array}{c}0.119^{* * *} \\
(0.0435)\end{array}$ \\
\hline Firm age & $\begin{array}{r}0.0163^{* * *} \\
(0.00357)\end{array}$ & $\begin{array}{r}0.0100^{* * *} \\
(0.00374)\end{array}$ \\
\hline MB ratio & $\begin{array}{l}0.0577^{*} \\
(0.0329)\end{array}$ & $\begin{array}{c}0.0716 \\
(0.0498)\end{array}$ \\
\hline$(\mathrm{CAPX}+\mathrm{R} \& \mathrm{D}) / \operatorname{lag}(\mathrm{AT})$ & $\begin{array}{l}-0.358 \\
(0.513)\end{array}$ & $\begin{array}{l}-0.660 \\
(0.572)\end{array}$ \\
\hline Sales growth rate & $\begin{array}{l}0.0324 \\
(0.115)\end{array}$ & $\begin{array}{c}0.128 \\
(0.153)\end{array}$ \\
\hline ROA & $\begin{array}{l}0.702^{*} \\
(0.380)\end{array}$ & $\begin{array}{l}0.0943 \\
(0.386)\end{array}$ \\
\hline Stock return & $\begin{array}{r}-0.0558 \\
(0.104)\end{array}$ & $\begin{array}{l}-0.127 \\
(0.0927)\end{array}$ \\
\hline Financial firm dummy & $\begin{array}{c}-0.947^{* * * *} \\
(0.198)\end{array}$ & $\begin{array}{c}-0.865^{* * *} \\
(0.172)\end{array}$ \\
\hline Institutional ownership & & $\begin{array}{l}0.135 \\
(0.407)\end{array}$ \\
\hline Blockholder presence & & $\begin{array}{l}0.0415 \\
(0.121)\end{array}$ \\
\hline Board size & & $\begin{array}{c}0.0175 \\
(0.0282)\end{array}$ \\
\hline Board independence ratio & & $\begin{array}{l}0.446^{*} \\
(0.258)\end{array}$ \\
\hline CEO's tenure & & $\begin{array}{c}-0.0544^{* * *} \\
(0.00933)\end{array}$ \\
\hline \# CEO's existing outside directorships & & $\begin{array}{c}0.405^{* * *} \\
(0.0621)\end{array}$ \\
\hline CEO's age & & $\begin{array}{l}0.0171^{* *} \\
(0.00747)\end{array}$ \\
\hline CEO's age $>62$ dummy & & $\begin{array}{c}-0.457^{* * *} \\
(0.158)\end{array}$ \\
\hline $\operatorname{Ln}($ CEO compensation $)$ & & $\begin{array}{c}0.0401 \\
(0.0540)\end{array}$ \\
\hline Equity-based compensation percent & & $\begin{array}{c}0.423 \\
(0.289)\end{array}$ \\
\hline CEO's beneficial ownership & & $\begin{array}{c}-0.0367^{* * *} \\
(0.0129)\end{array}$ \\
\hline Observations & 16,905 & 13,310 \\
\hline Year FE & Yes & Yes \\
\hline
\end{tabular}


Table 4. Univariate analyses of CEO firms' announcement effect

This table displays CEO firms' announcement effect of outside directorship appointments. Sample is from 1999 to 2012. The cumulative abnormal returns (CARs) are calculated over the $(-1,1)$ day event window adjusted by value-weighted market index, where $t=0$ is the announcement date. In Panel A, I report mean and median values for all firms. In Panel B, C, and D, I compare mean CARs of subsamples. Market value is the stock price at the end of a fiscal year multiplied by number of common shares outstanding. A firm's market share is the percentage of its sales in the same SIC2 industry. CEO's firm and the appointing firm are in the same industry based on Hoberg-Phillips classifications. Two firms operate in vertically related industries if these two industries have a customer-supplier relationship and either customer percentage or supplier percentage exceeds 1\% based on the Bureau of Economic Analysis Input-Output tables. Informationally related relation is defined following Hameed et al. (2015) with details in Appendix. Degree and eigenvector are two centrality measures for an individual in the network obtained from BoardEx. New business relationship means a new business transaction that starts at CEOs' outside directorship appointment year or in the following three years. One-sample t (median) tests are conducted to test whether each mean (median) value is significantly different from zero. Two-sample t tests (Wilcoxon-Mann-Whitney tests) are conducted to test whether the means (medians) of variables are significantly different across two groups. Statistical significance at 1\%, $5 \%$, and $10 \%$ level is indicated by $* * *, * *$, and $*$, respectively.

Panel A

\begin{tabular}{|c|c|c|}
\hline & Mean ( $p$ value) & Median ( $\mathrm{p}$ value) \\
\hline \multicolumn{3}{|l|}{ CEOs' own firms } \\
\hline $\mathrm{CAR}(-1,1)$ & $-0.01 \%(0.9672)$ & $0.05 \%(0.5543)$ \\
\hline $\operatorname{CAR}(-5,1)$ & $-0.04 \%(0.8619)$ & $0.26 \%(0.3642)$ \\
\hline $\operatorname{CAR}(-5,5)$ & $0.25 \%(0.3569)$ & $0.39 \%(0.1146)$ \\
\hline $\operatorname{CAR}(-10,1)$ & $-0.01 \%(0.9852)$ & $-0.12 \%(0.9953)$ \\
\hline $\operatorname{CAR}(-10,10)$ & $0.19 \%(0.6343)$ & $0.63 \%(0.1045)$ \\
\hline \multicolumn{3}{|l|}{ Appointing firms } \\
\hline $\operatorname{CAR}(-1,1)$ & $0.18 \%(0.2563)$ & $-0.06 \%(0.9804)$ \\
\hline $\mathrm{N}$ & 594 & \\
\hline
\end{tabular}

Panel B

\begin{tabular}{ccccc}
\hline \hline & $\begin{array}{c}\text { First outside } \\
\text { directorship }\end{array}$ & $\begin{array}{c}\text { Second outside } \\
\text { directorship }\end{array}$ & $\begin{array}{c}\text { Third outside } \\
\text { directorship }\end{array}$ & $\begin{array}{c}\text { Fourth outside } \\
\text { directorship }\end{array}$ \\
\cline { 2 - 5 } Mean & $0.27^{*}$ & -0.40 & 0.02 & -0.54 \\
\hline & & Second - First & Third - Second & Fourth - Third \\
\cline { 2 - 4 } & & $-0.67^{*}$ & 0.42 & 0.56 \\
\hline
\end{tabular}




\section{Panel C}

\begin{tabular}{|c|c|c|c|c|c|c|}
\hline & $\begin{array}{c}\text { CEO's } \\
\text { ownership } \\
<\text { median }\end{array}$ & $\begin{array}{c}\text { CEO's } \\
\text { ownership } \\
\text { >median }\end{array}$ & $\begin{array}{c}\text { No } \\
\text { blockholder }\end{array}$ & $\begin{array}{c}\text { With } \\
\text { blockholder }\end{array}$ & $\begin{array}{c}\text { E index } \\
>3\end{array}$ & $\begin{array}{c}\mathrm{E} \text { index } \\
<3\end{array}$ \\
\hline First outside directorship & $0.57^{* *}$ & -0.02 & $0.76^{* *}$ & 0.22 & -0.06 & $0.93^{*}$ \\
\hline Second outside directorship & -0.16 & $-0.71^{*}$ & -0.08 & -0.45 & -0.57 & -0.14 \\
\hline Difference & $0.73^{*}$ & 0.69 & 0.84 & $0.67^{*}$ & 0.51 & $1.07^{*}$ \\
\hline Second outside directorship & -0.16 & $-0.71^{*}$ & -0.08 & -0.45 & -0.57 & -0.14 \\
\hline Third outside directorship & -0.25 & 0.27 & 0.55 & -0.09 & 0.53 & -0.67 \\
\hline Difference & 0.09 & -0.97 & -0.63 & -0.36 & $-1.10^{*}$ & 0.53 \\
\hline Third outside directorship & -0.25 & 0.27 & 0.55 & -0.09 & 0.53 & -0.67 \\
\hline Fourth outside directorship & 0.04 & -1.05 & 0.94 & -0.93 & -0.01 & -2.01 \\
\hline Difference & -0.29 & 1.32 & -0.39 & 0.84 & 0.54 & 1.34 \\
\hline
\end{tabular}

Panel D

\begin{tabular}{lccc}
\hline \hline & Yes & No & Difference \\
\cline { 2 - 4 } & & & \\
Larger appointing firm (market value) & 0.56 & -0.3 & $0.86^{* *}$ \\
Larger appointing firm (market share) & 0.31 & 0.27 & 0.04 \\
Same industry & -0.69 & 0.34 & -1.03 \\
Vertically related & $1.12^{*}$ & 0.18 & $0.94^{*}$ \\
Informationally related & 0.38 & 0.04 & 0.34 \\
$\Delta$ Degree $>0$ & -0.33 & 0.28 & -0.61 \\
$\Delta$ Eigenvector $>0$ & 0.24 & 0.78 & -0.54 \\
New business relationship & $0.98^{*}$ & 0.19 & 0.79 \\
\hline
\end{tabular}


This table reports results from DID Panel OLS regressions. Dependent variable is $\triangle R O A_{t-3}$ to $t+3$, the average $R O A$ from year $\mathrm{t}+1$ to $\mathrm{t}+3$ minus the average $R O A$ from year $\mathrm{t}-3$ to $\mathrm{t}-1$ for each observation at year t. Sample of CEOs' outside director appointments is from 1999 to 2012. Treat dummy is an indicator for treated firms - firms whose CEO accepts a new outside directorship in year t. All other variables are defined in Appendix. All variables are winsorized at 1\% and 99\%. Standard errors are clustered at firm level. Statistical significance at 1\%, 5\%, and 10\% level is indicated by $* * *, * *$, and $*$, respectively.

\begin{tabular}{|c|c|c|c|c|c|}
\hline \multirow[b]{2}{*}{ Dependent variable } & (1) & (2) & (3) & (4) & (5) \\
\hline & \multicolumn{5}{|c|}{$\Delta R O A_{t-3}$ to $t+3$} \\
\hline Treat dummy & $\begin{array}{c}0.00298 \\
(0.00322)\end{array}$ & $\begin{array}{l}0.00700^{*} \\
(0.00364)\end{array}$ & $\begin{array}{c}0.00134 \\
(0.00363)\end{array}$ & $\begin{array}{l}-0.00183 \\
(0.00313)\end{array}$ & $\begin{array}{l}-0.00152 \\
(0.00360)\end{array}$ \\
\hline$\Delta \operatorname{Ln}($ Assets $)$ & & & $\begin{array}{c}-0.145^{* * *} \\
(0.0278)\end{array}$ & $\begin{array}{c}-0.138^{* * *} \\
(0.0125)\end{array}$ & $\begin{array}{c}-0.140 * * * \\
(0.0130)\end{array}$ \\
\hline$\Delta \mathrm{MB}$ & & & $\begin{array}{c}0.0243^{* *} \\
(0.0109)\end{array}$ & $\begin{array}{c}0.0101^{* * *} \\
(0.00204)\end{array}$ & $\begin{array}{c}0.00966^{* * *} \\
(0.00194)\end{array}$ \\
\hline$\Delta(\mathrm{CAPX}+\mathrm{R} \& \mathrm{D}) / \operatorname{lag}(\mathrm{AT})$ & & & & $\begin{array}{c}0.279^{* * *} \\
(0.105)\end{array}$ & $\begin{array}{c}0.264^{* * *} \\
(0.0956)\end{array}$ \\
\hline$\Delta$ Sales growth rate & & & & $\begin{array}{l}0.0341^{*} \\
(0.0178)\end{array}$ & $\begin{array}{c}0.0387^{* *} \\
(0.0195)\end{array}$ \\
\hline$\Delta \operatorname{Ln}($ Per capita personal income $)$ & & & & & $\begin{array}{c}-0.00945 \\
(0.0360)\end{array}$ \\
\hline$\Delta \operatorname{Ln}($ Unemployment rate $)$ & & & & & $\begin{array}{l}-0.00245 \\
(0.00151)\end{array}$ \\
\hline Observations & 14,940 & 14,878 & 14,878 & 14,706 & 12,986 \\
\hline R-squared & 0.000 & 0.199 & 0.312 & 0.358 & 0.378 \\
\hline Industry-Year FE & No & Yes & Yes & Yes & Yes \\
\hline
\end{tabular}


This table reports results from DID Panel 2SLS regressions. Panel A displays 1st-stage regression results. Panel $\mathrm{B}$ displays 2nd-stage regression results. $\triangle R O A_{t-3}$ to $t+3$ is the average $R O A$ from year $\mathrm{t}+1$ to $\mathrm{t}+3$ minus the average $R O A$ from year $\mathrm{t}-3$ to $\mathrm{t}-1$ for each observation at year $\mathrm{t}$. Treat dummy is an indicator for treated firms - firms whose CEO accepts a new outside directorship in year t. Distance is the distance between the headquarters of CEOs' firms and the appointing firms. All other variables are defined in Appendix. All variables are winsorized at 1\% and 99\%. Standard errors are clustered at treated firm level. Statistical significance at 1\%, $5 \%$, and $10 \%$ level is indicated by $* * *, * *$, and $*$, respectively.

Panel A. 1st-stage results

\begin{tabular}{|c|c|c|c|c|c|}
\hline \multirow[b]{2}{*}{ Dependent variable } & (1) & (2) & (3) & (4) & (5) \\
\hline & \multicolumn{5}{|c|}{ Treat dummy } \\
\hline $\operatorname{Ln}(1+$ distance to appointing firm $)$ & $\begin{array}{c}-0.0248^{* * *} \\
(0.00200)\end{array}$ & $\begin{array}{c}-0.0243^{* * *} \\
(0.00196)\end{array}$ & $\begin{array}{c}-0.0243^{* * *} \\
(0.00195)\end{array}$ & $\begin{array}{c}-0.0243^{* * *} \\
(0.00196)\end{array}$ & $\begin{array}{r}-0.0229 * * * \\
(0.00206)\end{array}$ \\
\hline$\Delta \operatorname{Ln}($ Assets $)$ & & & $\begin{array}{c}-0.0141^{* * *} \\
(0.00539)\end{array}$ & $\begin{array}{c}-0.0174^{* * *} \\
(0.00549)\end{array}$ & $\begin{array}{r}-0.0166^{* * *} \\
(0.00544)\end{array}$ \\
\hline$\Delta \mathrm{MB}$ & & & $\begin{array}{c}0.00136 \\
(0.000885)\end{array}$ & $\begin{array}{c}0.000951 \\
(0.000906)\end{array}$ & $\begin{array}{c}0.000988 \\
(0.000907)\end{array}$ \\
\hline$\Delta(\mathrm{CAPX}+\mathrm{R} \& \mathrm{D}) / \operatorname{lag}(\mathrm{AT})$ & & & & $\begin{array}{l}0.00534 \\
(0.0150)\end{array}$ & $\begin{array}{l}0.00570 \\
(0.0146)\end{array}$ \\
\hline$\Delta$ Sales growth rate & & & & $\begin{array}{c}0.00938^{* *} \\
(0.00398)\end{array}$ & $\begin{array}{r}0.00884^{* *} \\
(0.00364)\end{array}$ \\
\hline$\Delta \operatorname{Ln}($ Per capita personal income $)$ & & & & & $\begin{array}{l}-0.0371 \\
(0.0471)\end{array}$ \\
\hline$\Delta \operatorname{Ln}($ Unemployment rate $)$ & & & & & $\begin{array}{c}0.140 \\
(0.272)\end{array}$ \\
\hline Observations & 20,611 & 20,601 & 20,601 & 20,308 & 18,661 \\
\hline R-squared & 0.039 & 0.096 & 0.097 & 0.098 & 0.107 \\
\hline F statistics & 155 & 154 & 155 & 154 & 123 \\
\hline Industry-Year FE & No & Yes & Yes & Yes & Yes \\
\hline
\end{tabular}


Panel B. 2nd-stage results

\begin{tabular}{|c|c|c|c|c|c|}
\hline \multirow[b]{2}{*}{ Dependent variable } & (1) & $(2)$ & $(3)$ & $(4)$ & $(5)$ \\
\hline & \multicolumn{5}{|c|}{$\Delta R O A_{t-3}$ to $t+3$} \\
\hline Treat dummy & $\begin{array}{c}0.0443 \\
(0.0473)\end{array}$ & $\begin{array}{c}0.0363 \\
(0.0273)\end{array}$ & $\begin{array}{c}0.0302 \\
(0.0242)\end{array}$ & $\begin{array}{c}0.0252 \\
(0.0227)\end{array}$ & $\begin{array}{c}0.0343 \\
(0.0254)\end{array}$ \\
\hline$\Delta \operatorname{Ln}$ (Assets) & & & $\begin{array}{c}-0.108^{* * *} \\
(0.00611)\end{array}$ & $\begin{array}{c}-0.120^{* * *} \\
(0.00708)\end{array}$ & $\begin{array}{c}-0.120^{* * *} \\
(0.00725)\end{array}$ \\
\hline$\Delta \mathrm{MB}$ & & & $\begin{array}{r}0.0110^{* * *} \\
(0.00128)\end{array}$ & $\begin{array}{c}0.00940 * * * \\
(0.00121)\end{array}$ & $\begin{array}{c}0.00931^{* * * *} \\
(0.00118)\end{array}$ \\
\hline$\Delta(\mathrm{CAPX}+\mathrm{R} \& \mathrm{D}) / \operatorname{lag}(\mathrm{AT})$ & & & & $\begin{array}{c}0.0475^{* *} \\
(0.0194)\end{array}$ & $\begin{array}{c}0.0462^{* *} \\
(0.0202)\end{array}$ \\
\hline$\Delta$ Sales growth rate & & & & $\begin{array}{c}0.0286^{* * *} \\
(0.00441)\end{array}$ & $\begin{array}{c}0.0290^{* * *} \\
(0.00460)\end{array}$ \\
\hline$\Delta \operatorname{Ln}($ Per capita personal income $)$ & & & & & $\begin{array}{l}-0.0421 \\
(0.0290)\end{array}$ \\
\hline$\Delta \operatorname{Ln}($ Unemployment rate $)$ & & & & & $\begin{array}{r}-0.0693 \\
(0.128)\end{array}$ \\
\hline Observations & 20,611 & 20,601 & 20,601 & 20,308 & 18,661 \\
\hline R-squared & 0.002 & 0.227 & 0.306 & 0.312 & 0.313 \\
\hline Industry-Year FE & No & Yes & Yes & Yes & Yes \\
\hline
\end{tabular}




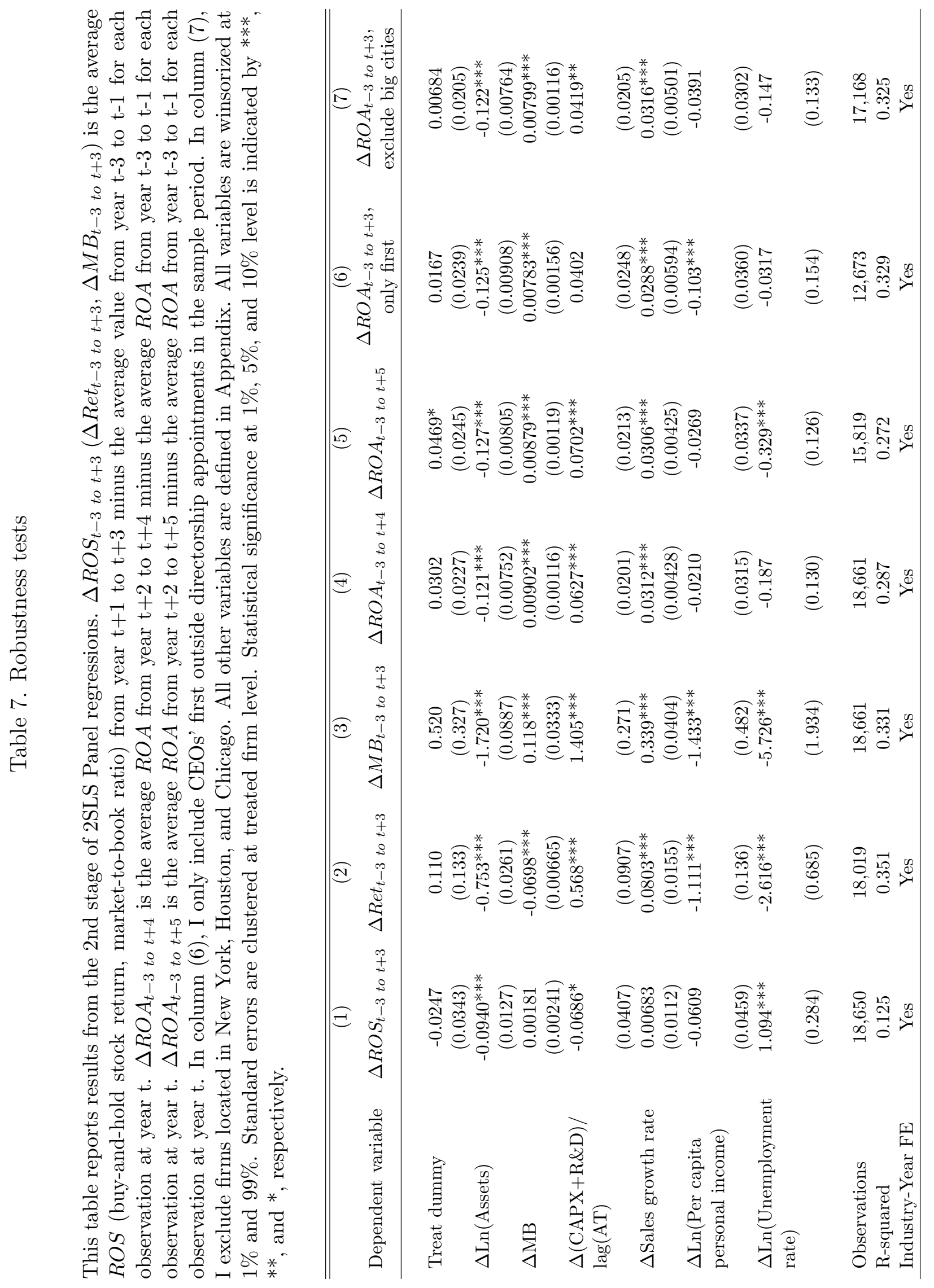


Table 8. Performance effect with agency proxy

This table reports results from the 2nd stage of 2SLS Panel regressions. $\triangle R O A_{t-3}$ to $t+3$ is the average $R O A$ from year $\mathrm{t}+1$ to $\mathrm{t}+3$ minus the average $R O A$ from year $\mathrm{t}-3$ to $\mathrm{t}-1$ for each observation at year t. Treat dummy is an indicator for treated firms - firms whose CEO accepts a new outside directorship in year t. All other variables are defined in Appendix. All variables are winsorized at $1 \%$ and $99 \%$. Standard errors are clustered at treated firm level. Statistical significance at 1\%, 5\%, and $10 \%$ level is indicated by ***, **, and $*$, respectively.

\begin{tabular}{|c|c|c|c|}
\hline \multirow{4}{*}{ Variable $\mathrm{C}$} & \multicolumn{3}{|c|}{ Dependent variable: $\Delta R O A_{t-3}$ to $t+3$} \\
\hline & (1) & $(2)$ & $(3)$ \\
\hline & CEO's ownership & No & E index $>3$ \\
\hline & $\begin{array}{c}<\text { sample median } \\
\text { dummy }\end{array}$ & $\begin{array}{l}\text { blockholder } \\
\text { dummy }\end{array}$ & dummy \\
\hline \multirow[t]{2}{*}{ Treat dummy $\times \mathrm{C}$} & $-0.107^{* *}$ & -0.0451 & $-0.0985^{* *}$ \\
\hline & $(0.0434)$ & $(0.0460)$ & $(0.0488)$ \\
\hline \multirow[t]{2}{*}{ Treat dummy } & $0.0616^{*}$ & $0.0472^{*}$ & $0.0494^{*}$ \\
\hline & $(0.0339)$ & $(0.0273)$ & $(0.0291)$ \\
\hline \multirow[t]{2}{*}{$\mathrm{C}$} & $0.00749^{* * *}$ & -0.00245 & $0.00742^{* * *}$ \\
\hline & $(0.00233)$ & $(0.00223)$ & $(0.00250)$ \\
\hline \multirow[t]{2}{*}{$\Delta \operatorname{Ln}($ Assets $)$} & $-0.113^{* * *}$ & $-0.119^{* * *}$ & $-0.105^{* * *}$ \\
\hline & $(0.00732)$ & $(0.00723)$ & $(0.0106)$ \\
\hline \multirow[t]{2}{*}{$\Delta \mathrm{MB}$} & $0.0108^{* * *}$ & $0.00985^{* * *}$ & $0.00809^{* * *}$ \\
\hline & $(0.00128)$ & $(0.00118)$ & $(0.00188)$ \\
\hline \multirow{2}{*}{$\Delta(\mathrm{CAPX}+\mathrm{R} \& \mathrm{D}) / \operatorname{lag}(\mathrm{AT})$} & $0.0363^{* *}$ & $0.0468^{* *}$ & 0.0294 \\
\hline & $(0.0179)$ & $(0.0198)$ & $(0.0302)$ \\
\hline \multirow[t]{2}{*}{$\Delta$ Sales growth rate } & $0.0255^{* * *}$ & $0.0290^{* * *}$ & $0.0249 * * *$ \\
\hline & $(0.00432)$ & $(0.00455)$ & $(0.00700)$ \\
\hline \multirow[t]{2}{*}{$\Delta \operatorname{Ln}($ Per capita personal income $)$} & $-0.0802^{* *}$ & $-0.0525^{*}$ & -0.0219 \\
\hline & $(0.0322)$ & $(0.0282)$ & $(0.0301)$ \\
\hline \multirow[t]{2}{*}{$\Delta \operatorname{Ln}($ Unemployment rate $)$} & -0.119 & -0.112 & -0.115 \\
\hline & $(0.137)$ & $(0.127)$ & $(0.125)$ \\
\hline Observations & 17,835 & 18,921 & 11,407 \\
\hline R-squared & 0.303 & 0.315 & 0.264 \\
\hline Industry-Year FE & Yes & Yes & Yes \\
\hline \multirow[t]{2}{*}{ Treat dummy $\times \mathrm{C}+$ Treat dummy } & -0.0454 & 0.0021 & -0.0491 \\
\hline & $(0.1088)$ & $(0.9572)$ & $(0.1609)$ \\
\hline
\end{tabular}


Table 9. Performance effect of multiple outside directorships

This table reports results from the 2nd stage of 2SLS Panel regressions. $\triangle R O A_{t-3}$ to $t+3$ is the average $R O A$ from year $\mathrm{t}+1$ to $\mathrm{t}+3$ minus the average $R O A$ from year $\mathrm{t}-3$ to $\mathrm{t}-1$ for each observation at year t. Treat dummy is an indicator for treated firms - firms whose CEO accepts a new outside directorship in year t. First (second, third, fourth) outside directorship dummy is equal 1 if a CEO already holds zero (one, two, three) outside directorships. All other variables are defined in Appendix. All variables are winsorized at 1\% and 99\%. Standard errors are clustered at treated firm level. Statistical significance at $1 \%, 5 \%$, and $10 \%$ level is indicated by $* * *$, $* *$, and $*$, respectively.

Panel A. Multiple outside directorships

\begin{tabular}{|c|c|c|c|c|}
\hline & 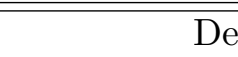 & endent variab & $\overline{: \Delta R O A_{t-3 t}}$ & \\
\hline & (1) & $(2)$ & $(3)$ & (4) \\
\hline Variable C & $\begin{array}{l}\text { First outside } \\
\text { directorship } \\
\text { dummy }\end{array}$ & $\begin{array}{c}\text { Second } \\
\text { outside } \\
\text { directorship } \\
\text { dummy }\end{array}$ & $\begin{array}{c}\text { Third } \\
\text { outside } \\
\text { directorship } \\
\text { dummy }\end{array}$ & $\begin{array}{c}\text { Fourth } \\
\text { outside } \\
\text { directorship } \\
\text { dummy }\end{array}$ \\
\hline Treat dummy $\times \mathrm{C}$ & $0.0822^{*}$ & $-0.103^{* *}$ & 0.00457 & $8.91 \mathrm{e}-05$ \\
\hline & $(0.0436)$ & $(0.0481)$ & $(0.0369)$ & $(0.0545)$ \\
\hline Treat dummy & -0.0107 & $0.0715^{*}$ & 0.0343 & 0.0340 \\
\hline & $(0.0169)$ & $(0.0424)$ & $(0.0288)$ & $(0.0246)$ \\
\hline $\mathrm{C}$ & $-0.00409^{*}$ & $0.00755^{* * *}$ & $-0.0145^{* * *}$ & -0.00636 \\
\hline & $(0.00211)$ & $(0.00263)$ & $(0.00452)$ & $(0.0148)$ \\
\hline$\Delta \operatorname{Ln}($ Assets $)$ & $-0.118^{* * *}$ & $-0.119^{* * *}$ & $-0.119^{* * *}$ & $-0.119^{* * *}$ \\
\hline & $(0.00729)$ & $(0.00735)$ & $(0.00724)$ & $(0.00724)$ \\
\hline$\Delta \mathrm{MB}$ & $0.00983^{* * *}$ & $0.00971^{* * *}$ & $0.00982^{* * *}$ & $0.00977^{* * *}$ \\
\hline & $(0.00118)$ & $(0.00119)$ & $(0.00119)$ & $(0.00118)$ \\
\hline$\Delta(\mathrm{CAPX}+\mathrm{R} \& \mathrm{D}) / \operatorname{lag}(\mathrm{AT})$ & $0.0449 * *$ & $0.0449 * *$ & $0.0476^{* *}$ & $0.0466^{* *}$ \\
\hline & $(0.0199)$ & $(0.0202)$ & $(0.0199)$ & $(0.0198)$ \\
\hline$\Delta$ Sales growth rate & $0.0291^{* * *}$ & $0.0292^{* * *}$ & $0.0292^{* * *}$ & $0.0290 * * *$ \\
\hline & $(0.00456)$ & $(0.00467)$ & $(0.00454)$ & $(0.00452)$ \\
\hline$\Delta \operatorname{Ln}($ Per capita personal income $)$ & $-0.0549^{*}$ & $-0.0660 * *$ & $-0.0551^{*}$ & $-0.0536^{*}$ \\
\hline & $(0.0286)$ & $(0.0295)$ & $(0.0284)$ & $(0.0282)$ \\
\hline$\Delta \operatorname{Ln}($ Unemployment rate) & -0.125 & -0.145 & -0.0964 & -0.109 \\
\hline & $(0.125)$ & $(0.128)$ & $(0.127)$ & $(0.126)$ \\
\hline Observations & 18,921 & 18,345 & 18,833 & 18,910 \\
\hline R-squared & 0.312 & 0.309 & 0.317 & 0.316 \\
\hline Industry-Year FE & Yes & Yes & Yes & Yes \\
\hline Treat dummy $\times \mathrm{C}+$ Treat & $0.0715^{*}$ & -0.0315 & $0.0389^{*}$ & 0.0340 \\
\hline & $(0.0896)$ & $(0.2579)$ & $(0.0547)$ & $(0.4852)$ \\
\hline
\end{tabular}




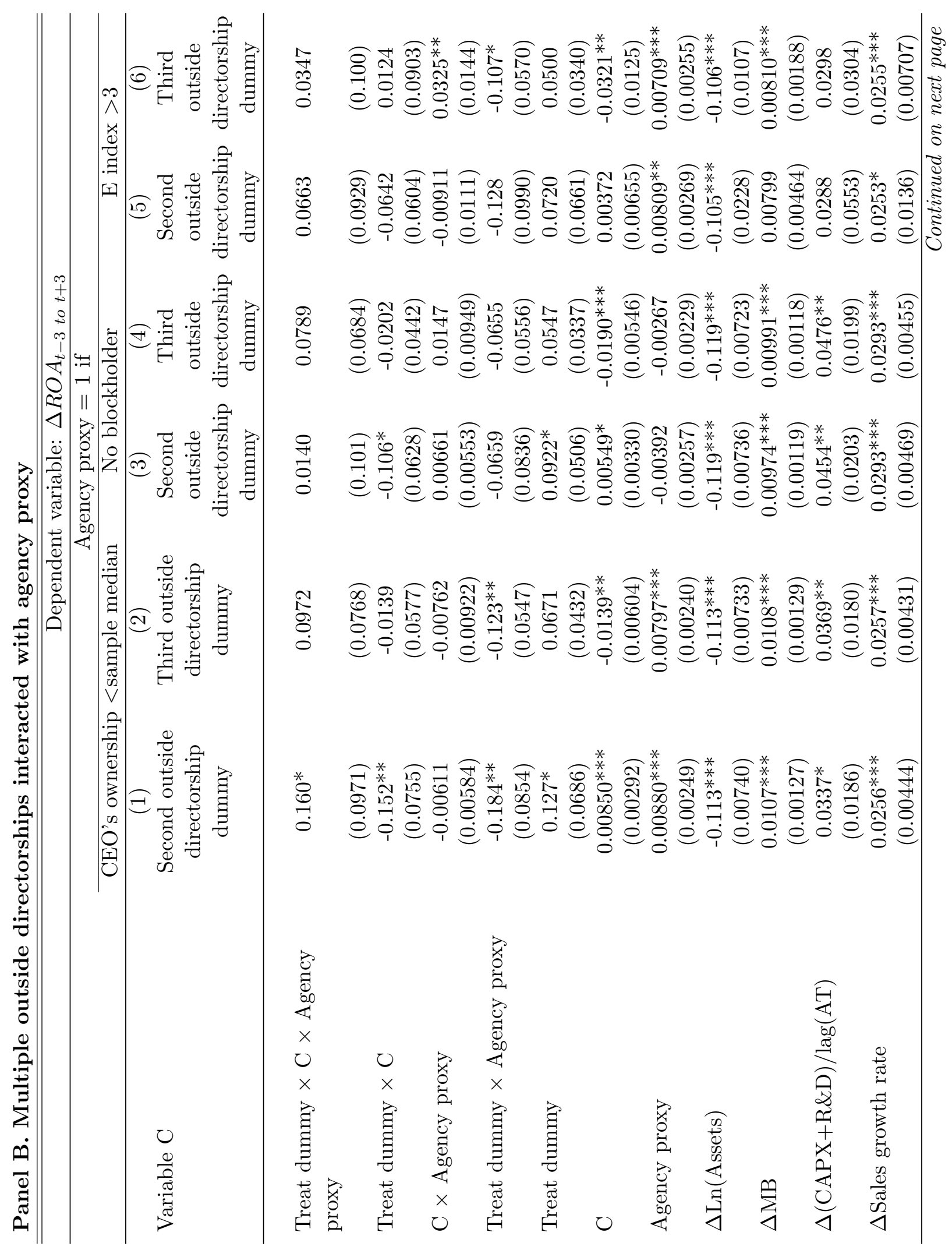




\begin{tabular}{|c|c|c|c|c|c|c|}
\hline & $(1)$ & $(2)$ & $(3)$ & $(4)$ & $(5)$ & (6) \\
\hline \multirow[t]{2}{*}{$\Delta \operatorname{Ln}($ Per capita personal income $)$} & $-0.0917^{* * *}$ & $-0.0817^{* *}$ & $-0.0643^{* *}$ & $-0.0535^{*}$ & -0.0324 & -0.0249 \\
\hline & $(0.0339)$ & $(0.0324)$ & $(0.0296)$ & $(0.0284)$ & $(0.0518)$ & $(0.0307)$ \\
\hline \multirow[t]{2}{*}{$\Delta \operatorname{Ln}($ Unemployment rate $)$} & -0.154 & -0.112 & -0.149 & -0.0969 & -0.154 & -0.119 \\
\hline & $(0.139)$ & $(0.138)$ & $(0.130)$ & $(0.128)$ & $(0.224)$ & $(0.127)$ \\
\hline Observations & 17,260 & 17,747 & 18,345 & 18,833 & 11,134 & 11,375 \\
\hline R-squared & 0.292 & 0.303 & 0.308 & 0.315 & 0.262 & 0.265 \\
\hline Industry-Year FE & Yes & Yes & Yes & Yes & Yes & Yes \\
\hline \multirow{2}{*}{$\begin{array}{l}\text { Treat dummy } \times \mathrm{C} \times \text { Agency } \\
\text { proxy }+ \text { Treat dummy } \times \text { Agency } \\
\text { proxy }\end{array}$} & -0.024 & -0.0258 & -0.0519 & 0.0134 & -0.0617 & -0.0723 \\
\hline & $(0.6276)$ & $(0.5432)$ & $(0.3414)$ & $(0.7241)$ & $(0.4931)$ & $(0.3366)$ \\
\hline \multirow{2}{*}{$\begin{array}{l}\text { Treat dummy } \times \mathrm{C} \times \text { Agency } \\
\text { proxy }+ \text { Treat dummy } \times \mathrm{C}+ \\
\text { Treat dummy } \times \text { Agency proxy }+ \\
\text { Treat dummy }\end{array}$} & -0.049 & 0.0274 & $-0.0657^{*}$ & $0.0479^{*}$ & -0.0539 & -0.0099 \\
\hline & $(0.1444)$ & $(0.2789)$ & $(0.0992)$ & $(0.0884)$ & $(0.4195)$ & $(0.5766)$ \\
\hline
\end{tabular}


Table 10. Expected number of outside directorships

This table reports results from the 2nd stage of 2SLS Panel regressions. $\triangle R O A_{t-3}$ to $t+3$ is the average $R O A$ from year $\mathrm{t}+1$ to $\mathrm{t}+3$ minus the average $R O A$ from year $\mathrm{t}-3$ to $\mathrm{t}-1$ for each observation at year t. \# CEOs' existing directorships are hand collected from appointing firms' proxy statements. CEOs' expected numbers of outside directorships are obtained from a Poisson regression. The results of the Poisson regression are reported in Appendix Table A3. All other variables are defined in Appendix. All variables are winsorized at 1\% and 99\%. Standard errors are clustered at treated firm level. Statistical significance at 1\%, $5 \%$, and $10 \%$ level is indicated by $* * *, * *$, and $*$, respectively.

\begin{tabular}{|c|c|c|c|c|}
\hline \multirow[b]{5}{*}{ Variable $\mathrm{C}$} & \multicolumn{4}{|c|}{ Dependent variable: $\Delta R O A_{t-3}$ to $t+3$} \\
\hline & & \multicolumn{3}{|c|}{ Agency proxy $=1$ if } \\
\hline & & $\begin{array}{c}\text { CEO's } \\
\text { ownership } \\
<\text { sample } \\
\text { median }\end{array}$ & $\begin{array}{c}\text { No } \\
\text { blockholder }\end{array}$ & E index $>3$ \\
\hline & (1) & $(2)$ & $(3)$ & (4) \\
\hline & \multicolumn{4}{|c|}{$\begin{aligned} \text { Dummy }= & 1 \text { if \# CEO's existing outside directorships }> \\
& \text { Estimated \# outside directorships }\end{aligned}$} \\
\hline Treat dummy $\times \mathrm{C} \times$ Agency proxy & & $\begin{array}{c}0.136 \\
(0.0840)\end{array}$ & $\begin{array}{c}0.00298 \\
(0.105)\end{array}$ & $\begin{array}{c}0.0842 \\
(0.0974)\end{array}$ \\
\hline Treat dummy $\times \mathrm{C}$ & $\begin{array}{r}-0.0811^{*} \\
(0.0452)\end{array}$ & $\begin{array}{l}-0.135^{*} \\
(0.0704)\end{array}$ & $\begin{array}{l}-0.0817 \\
(0.0557)\end{array}$ & $\begin{array}{l}-0.0652 \\
(0.0663)\end{array}$ \\
\hline $\mathrm{C} \times$ Agency proxy & & $\begin{array}{l}-0.00631 \\
(0.00618)\end{array}$ & $\begin{array}{c}0.00544 \\
(0.00535)\end{array}$ & $\begin{array}{c}-0.000994 \\
(0.00541)\end{array}$ \\
\hline Treat dummy $\times$ Agency proxy & & $\begin{array}{r}-0.168^{* *} \\
(0.0761)\end{array}$ & $\begin{array}{l}-0.0240 \\
(0.0956)\end{array}$ & $\begin{array}{l}-0.148^{*} \\
(0.0839)\end{array}$ \\
\hline Treat dummy & $\begin{array}{l}0.0734^{*} \\
(0.0437)\end{array}$ & $\begin{array}{l}0.137^{* *} \\
(0.0688)\end{array}$ & $\begin{array}{c}0.0806 \\
(0.0496)\end{array}$ & $\begin{array}{c}0.0791 \\
(0.0516)\end{array}$ \\
\hline $\mathrm{C}$ & $\begin{array}{c}0.00517^{* *} \\
(0.00234)\end{array}$ & $\begin{array}{l}0.00646^{* *} \\
(0.00265)\end{array}$ & $\begin{array}{c}0.00363 \\
(0.00293)\end{array}$ & $\begin{array}{l}0.000784 \\
(0.00377)\end{array}$ \\
\hline Agency proxy & & $\begin{array}{c}0.00935^{* * *} \\
(0.00284)\end{array}$ & $\begin{array}{l}-0.00313 \\
(0.00319)\end{array}$ & $\begin{array}{c}0.00848^{* * *} \\
(0.00327)\end{array}$ \\
\hline$\Delta \operatorname{Ln}($ Assets $)$ & $\begin{array}{c}-0.105^{* * *} \\
(0.00871)\end{array}$ & $\begin{array}{l}-0.105^{* * *} \\
(0.00868)\end{array}$ & $\begin{array}{c}-0.105^{* * *} \\
(0.00871)\end{array}$ & $\begin{array}{c}-0.0924^{* * *} \\
(0.0127)\end{array}$ \\
\hline$\Delta \mathrm{MB}$ & $\begin{array}{c}0.00951^{* * *} \\
(0.00142)\end{array}$ & $\begin{array}{c}0.00958^{* * *} \\
(0.00142)\end{array}$ & $\begin{array}{c}0.00952^{* * *} \\
(0.00142)\end{array}$ & $\begin{array}{c}0.00749^{* * *} \\
(0.00215)\end{array}$ \\
\hline$\Delta(\mathrm{CAPX}+\mathrm{R} \& \mathrm{D}) / \operatorname{lag}(\mathrm{AT})$ & $\begin{array}{c}0.0355^{*} \\
(0.0198)\end{array}$ & $\begin{array}{c}0.0361^{*} \\
(0.0198)\end{array}$ & $\begin{array}{l}0.0361^{*} \\
(0.0200)\end{array}$ & $\begin{array}{c}0.00132 \\
(0.0292)\end{array}$ \\
\hline$\Delta$ Sales growth rate & $\begin{array}{c}0.0206^{* * *} \\
(0.00485)\end{array}$ & $\begin{array}{c}0.0202^{* * *} \\
(0.00480)\end{array}$ & $\begin{array}{c}0.0207^{* * *} \\
(0.00485)\end{array}$ & $\begin{array}{l}0.0186^{* *} \\
(0.00780)\end{array}$ \\
\hline$\Delta \operatorname{Ln}($ Per capita personal income $)$ & $\begin{array}{c}-0.108^{* * *} \\
(0.0355)\end{array}$ & $\begin{array}{c}-0.101^{* * *} \\
(0.0359)\end{array}$ & $\begin{array}{c}-0.108^{* * *} \\
(0.0354)\end{array}$ & $\begin{array}{c}-0.0231 \\
(0.0356)\end{array}$ \\
\hline$\Delta \operatorname{Ln}($ Unemployment rate $)$ & $\begin{array}{c}-0.351^{* *} \\
(0.149)\end{array}$ & $\begin{array}{c}-0.357^{* *} \\
(0.150)\end{array}$ & $\begin{array}{c}-0.362^{* *} \\
(0.151)\end{array}$ & $\begin{array}{l}-0.274^{*} \\
(0.143)\end{array}$ \\
\hline Observations & 14,634 & 14,634 & 14,634 & 9,163 \\
\hline R-squared & 0.304 & 0.296 & 0.303 & 0.248 \\
\hline Industry-Year FE & Yes & Yes & Yes & Yes \\
\hline
\end{tabular}




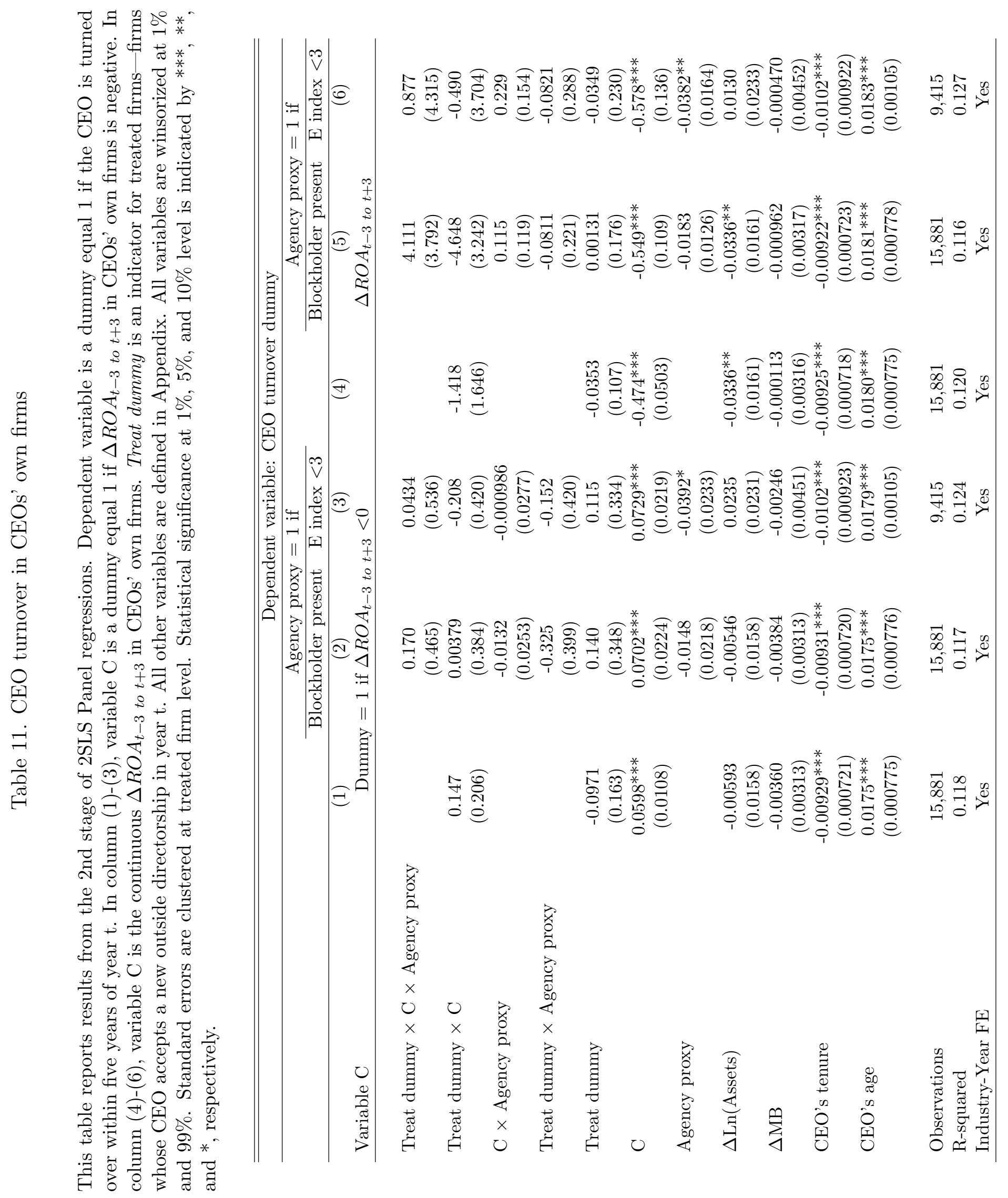




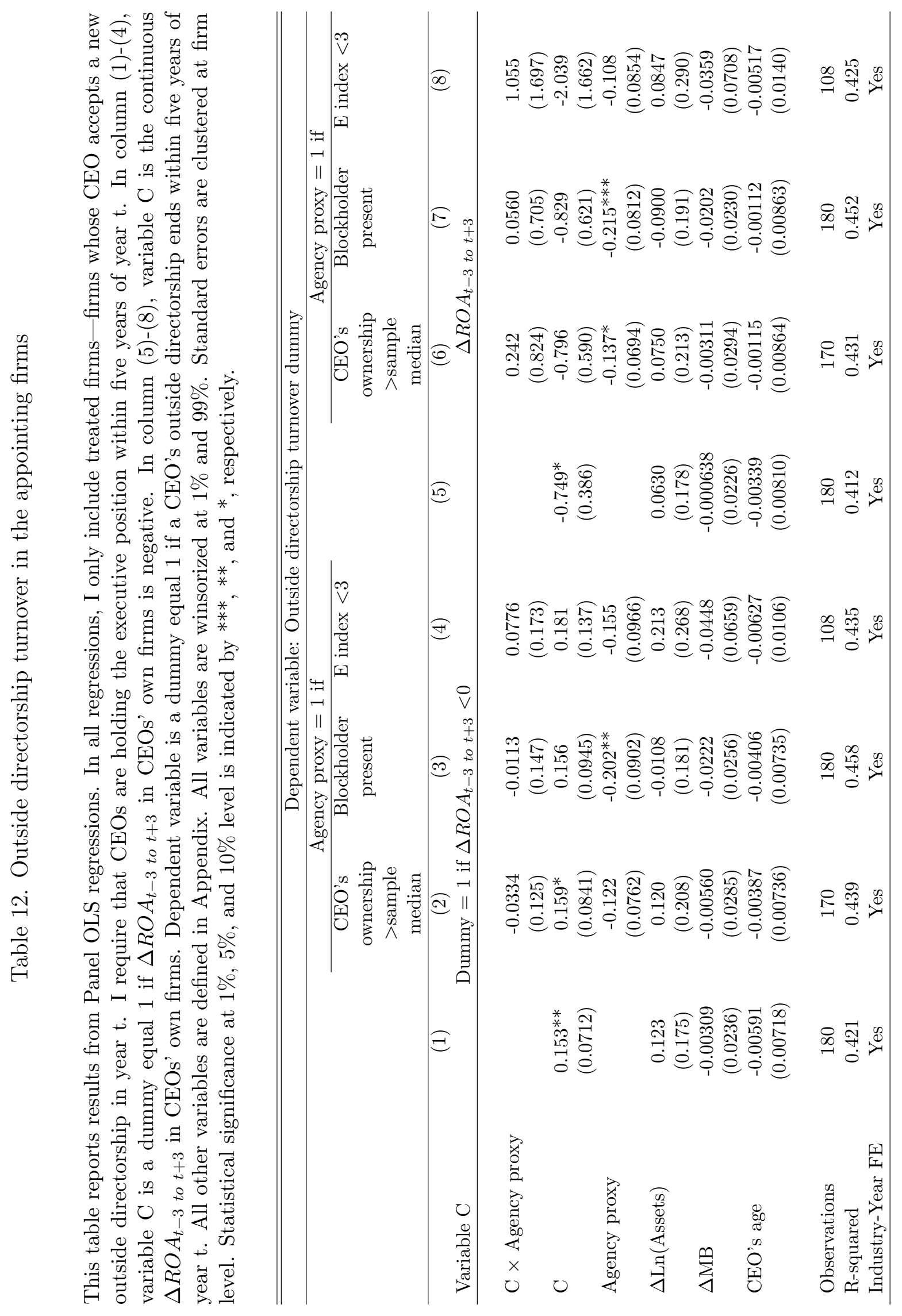




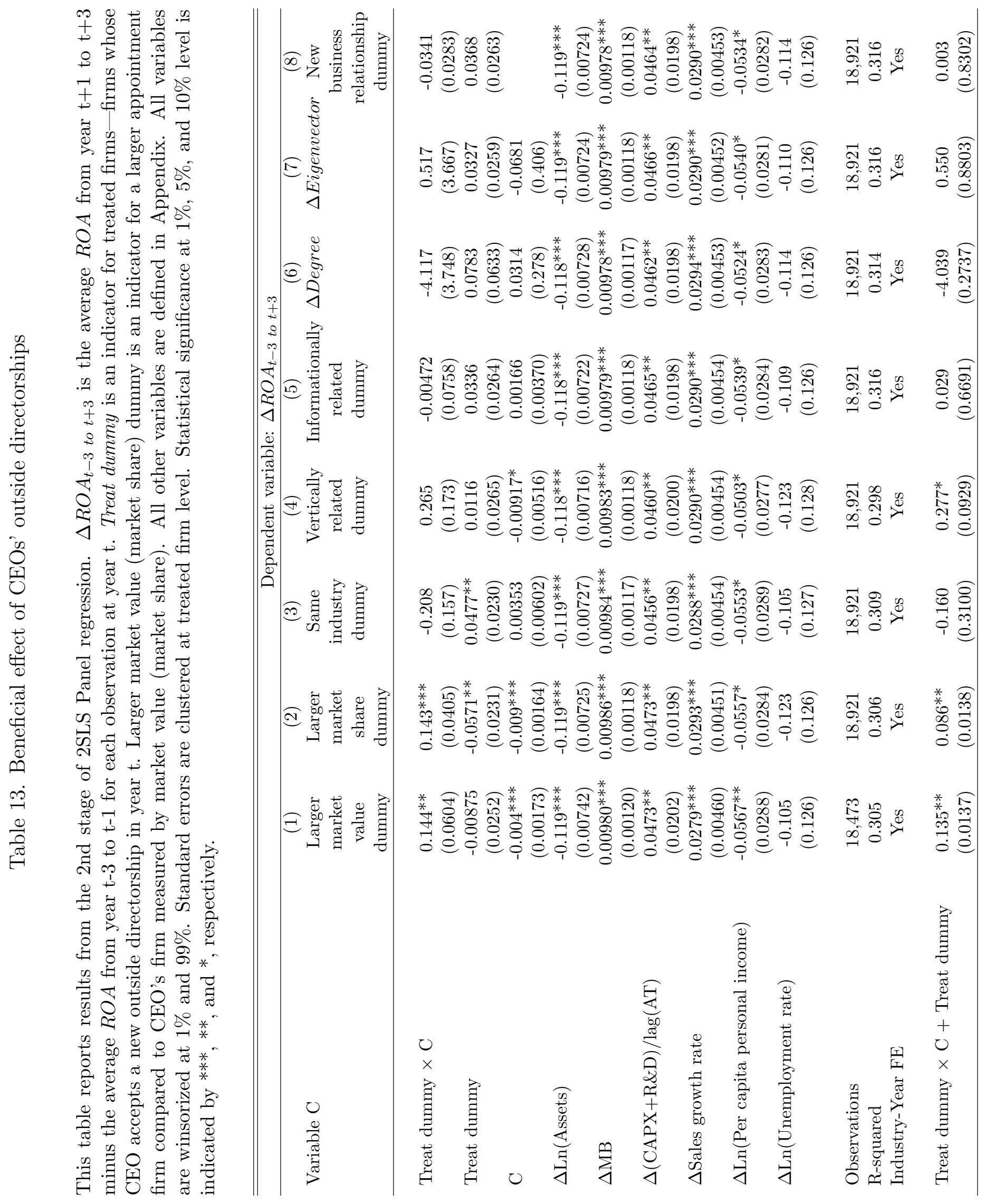


Table 14. CEOs' general managerial ability

This table reports results from the 2nd stage of 2SLS Panel regression. $\triangle R O A_{t-3}$ to $t+3$ is the average $R O A$ from year $\mathrm{t}+1$ to $\mathrm{t}+3$ minus the average $R O A$ from year $\mathrm{t}-3$ to $\mathrm{t}-1$ for each observation at year t. Treat dummy is an indicator for treated firms - firms whose CEO accepts a new outside directorship in year t. The definition of CEO's General Ability (GA) Index and all other variables are in Appendix. Negative GA index dummy is equal 1 for CEOs with a negative standardized GA index. All variables are winsorized at $1 \%$ and $99 \%$. Standard errors are clustered at treated firm level. Statistical significance at $1 \%, 5 \%$, and $10 \%$ level is indicated by $* * *, * *$, and ${ }^{*}$, respectively.

\begin{tabular}{|c|c|c|}
\hline & Dependent varia & $\Delta R O A_{t-3}$ to $t+3$ \\
\hline Variable $\mathrm{C}$ & $\begin{array}{c}(1) \\
\text { Larger market value } \\
\text { dummy }\end{array}$ & $\begin{array}{c}(2) \\
\text { Larger market share } \\
\text { dummy }\end{array}$ \\
\hline Treat dummy $\times \mathrm{C} \times$ Negative GA index dummy & $\begin{array}{l}0.0618 \\
(0.173)\end{array}$ & $\begin{array}{c}0.339^{* * *} \\
(0.122)\end{array}$ \\
\hline Treat dummy $\times \mathrm{C}$ & $\begin{array}{c}0.121^{* *} \\
(0.0548)\end{array}$ & $\begin{array}{c}0.0191 \\
(0.0396)\end{array}$ \\
\hline Treat dummy $\times$ Negative GA index dummy & $\begin{array}{c}0.120 \\
(0.0814)\end{array}$ & $\begin{array}{l}-0.0865 \\
(0.0721)\end{array}$ \\
\hline $\mathrm{C} \times$ Negative GA index dummy & $\begin{array}{c}0.00343 \\
(0.00416)\end{array}$ & $\begin{array}{l}-0.00145 \\
(0.00472)\end{array}$ \\
\hline Treat dummy & $\begin{array}{c}-0.0526^{* *} \\
(0.0220)\end{array}$ & $\begin{array}{l}-0.0269 \\
(0.0260)\end{array}$ \\
\hline $\mathrm{C}$ & $\begin{array}{c}-0.00636^{* * *} \\
(0.00230)\end{array}$ & $\begin{array}{c}-0.00788^{* * *} \\
(0.00253)\end{array}$ \\
\hline Negative GA index dummy & $\begin{array}{l}-0.00177 \\
(0.00324)\end{array}$ & $\begin{array}{c}0.00175 \\
(0.00422)\end{array}$ \\
\hline$\Delta \operatorname{Ln}($ Assets $)$ & $\begin{array}{l}-0.118^{* * *} \\
(0.00714)\end{array}$ & $\begin{array}{r}-0.118^{* * *} \\
(0.00700)\end{array}$ \\
\hline$\Delta \mathrm{MB}$ & $\begin{array}{c}0.00995^{* * *} \\
(0.00115)\end{array}$ & $\begin{array}{l}0.0100^{* * *} \\
(0.00114)\end{array}$ \\
\hline$\Delta(\mathrm{CAPX}+\mathrm{R} \& \mathrm{D}) / \operatorname{lag}(\mathrm{AT})$ & $\begin{array}{r}0.0446^{* *} \\
(0.0201)\end{array}$ & $\begin{array}{c}0.0432^{* *} \\
(0.0200)\end{array}$ \\
\hline$\Delta$ Sales growth rate & $\begin{array}{c}0.0275^{* * *} \\
(0.00461)\end{array}$ & $\begin{array}{c}0.0292^{* * *} \\
(0.00453)\end{array}$ \\
\hline$\Delta \operatorname{Ln}($ Per capita personal income $)$ & $\begin{array}{c}-0.0666^{* *} \\
(0.0292)\end{array}$ & $\begin{array}{c}-0.0648^{* *} \\
(0.0290)\end{array}$ \\
\hline$\Delta \operatorname{Ln}($ Unemployment rate $)$ & $\begin{array}{l}-0.103 \\
(0.127)\end{array}$ & $\begin{array}{c}-0.0905 \\
(0.127)\end{array}$ \\
\hline Observations & 18,354 & 18,800 \\
\hline R-squared & 0.301 & 0.291 \\
\hline Industry-Year FE & Yes & Yes \\
\hline
\end{tabular}


Table 15. CEOs without previous outside director experiences

This table reports results from the 2nd stage of 2SLS Panel regressions. $\triangle R O A_{t-3}$ to $t+3$ is the average $R O A$ from year $\mathrm{t}+1$ to $\mathrm{t}+3$ minus the average $R O A$ from year $\mathrm{t}-3$ to $\mathrm{t}-1$ for each observation at year t. No experience dummy is equal 1 for CEOs who do not have any previous experiences being an outside director at another firm. All other variables are defined in Appendix. All variables are winsorized at $1 \%$ and $99 \%$. Standard errors are clustered at treated firm level. Statistical significance at $1 \%, 5 \%$, and $10 \%$ level is indicated by $* * *, * *$, and $*$, respectively.

\begin{tabular}{|c|c|c|c|}
\hline \multirow[b]{3}{*}{ Variable $\mathrm{C}$} & \multicolumn{3}{|c|}{ Dependent variable: $\Delta R O A_{t-3}$ to $t+3$} \\
\hline & $(1)$ & $(2)$ & $(3)$ \\
\hline & & $\begin{array}{l}\text { Larger market } \\
\text { value dummy }\end{array}$ & $\begin{array}{l}\text { Larger market } \\
\text { share dummy }\end{array}$ \\
\hline Treat dummy $\times$ No exp. dummy $\times \mathrm{C}$ & & $\begin{array}{l}0.254^{*} \\
(0.149)\end{array}$ & $\begin{array}{c}0.382^{* * *} \\
(0.119)\end{array}$ \\
\hline Treat dummy $\times$ No exp. dummy & $\begin{array}{l}0.151^{* *} \\
(0.0653)\end{array}$ & $\begin{array}{c}0.109^{*} \\
(0.0591)\end{array}$ & $\begin{array}{c}-0.103 \\
(0.0706)\end{array}$ \\
\hline No exp. dummy $\times \mathrm{C}$ & & $\begin{array}{l}-0.00180 \\
(0.00414)\end{array}$ & $\begin{array}{l}-0.00507 \\
(0.00396)\end{array}$ \\
\hline Treat dummy $\times \mathrm{C}$ & & $\begin{array}{c}0.0670 \\
(0.0435)\end{array}$ & $\begin{array}{l}0.00494 \\
(0.0347)\end{array}$ \\
\hline Treat dummy & $\begin{array}{l}-0.0222 \\
(0.0168)\end{array}$ & $\begin{array}{c}-0.0484^{* *} \\
(0.0215)\end{array}$ & $\begin{array}{l}-0.0259 \\
(0.0235)\end{array}$ \\
\hline No exp. dummy & $\begin{array}{r}-0.00314^{*} \\
(0.00182)\end{array}$ & $\begin{array}{l}-0.00230 \\
(0.00263)\end{array}$ & $\begin{array}{c}0.00161 \\
(0.00324)\end{array}$ \\
\hline $\mathrm{C}$ & & $\begin{array}{l}-0.00295 \\
(0.00331)\end{array}$ & $\begin{array}{c}-0.00576^{*} \\
(0.00299)\end{array}$ \\
\hline$\Delta \operatorname{Ln}($ Assets $)$ & $\begin{array}{r}-0.118^{* * *} \\
(0.00735)\end{array}$ & $\begin{array}{r}-0.118^{* * *} \\
(0.00755)\end{array}$ & $\begin{array}{l}-0.118^{* * *} \\
(0.00738)\end{array}$ \\
\hline$\Delta \mathrm{MB}$ & $\begin{array}{c}0.00995^{* * *} \\
(0.00119)\end{array}$ & $\begin{array}{c}0.00999^{* * *} \\
(0.00122)\end{array}$ & $\begin{array}{c}0.0100^{* * *} \\
(0.00119)\end{array}$ \\
\hline$\Delta(\mathrm{CAPX}+\mathrm{R} \& \mathrm{D}) / \operatorname{lag}(\mathrm{AT})$ & $\begin{array}{c}0.0418^{* *} \\
(0.0200)\end{array}$ & $\begin{array}{c}0.0416^{* *} \\
(0.0204)\end{array}$ & $\begin{array}{c}0.0425^{* *} \\
(0.0199)\end{array}$ \\
\hline$\Delta$ Sales growth rate & $\begin{array}{r}0.0291^{* * *} \\
(0.00463)\end{array}$ & $\begin{array}{c}0.0281^{* * *} \\
(0.00472)\end{array}$ & $\begin{array}{c}0.0295^{* * *} \\
(0.00461)\end{array}$ \\
\hline$\Delta \operatorname{Ln}($ Per capita personal income $)$ & $\begin{array}{c}-0.0613^{* *} \\
(0.0293)\end{array}$ & $\begin{array}{c}-0.0646^{* *} \\
(0.0300)\end{array}$ & $\begin{array}{c}-0.0664^{* *} \\
(0.0294)\end{array}$ \\
\hline$\Delta \operatorname{Ln}($ Unemployment rate $)$ & $\begin{array}{l}-0.159 \\
(0.128)\end{array}$ & $\begin{array}{l}-0.161 \\
(0.130)\end{array}$ & $\begin{array}{l}-0.200 \\
(0.132)\end{array}$ \\
\hline Observations & 18,617 & 18,178 & 18,617 \\
\hline R-squared & 0.304 & 0.280 & 0.276 \\
\hline Industry-Year FE & Yes & Yes & Yes \\
\hline
\end{tabular}


Table 16. Marginal beneficial effect with multiple outside directorships

This table reports results from the 2nd stage of 2SLS Panel regression. $\triangle R O A_{t-3}$ to $t+3$ is the average $R O A$ from year $\mathrm{t}+1$ to $\mathrm{t}+3$ minus the average $R O A$ from year $\mathrm{t}-3$ to $\mathrm{t}-1$ for each observation at year t. Treat dummy is an indicator for treated firms - firms whose CEO accepts a new outside directorship in year t. Larger market value (market share) dummy is an indicator for a larger appointment firm compared to CEO's firm measured by market value (market share). All other variables are defined in Appendix. All variables are winsorized at 1\% and 99\%. Standard errors are clustered at treated firm level. Statistical significance at 1\%, $5 \%$, and $10 \%$ level is indicated by ***, **, and *, respectively.

\begin{tabular}{|c|c|c|}
\hline & \multicolumn{2}{|c|}{ Dependent variable: $\Delta R O A_{t-3}$ to $t+3$} \\
\hline \multirow[b]{2}{*}{ Variable $\mathrm{C}$} & (1) & $(2)$ \\
\hline & $\begin{array}{l}\text { Larger market } \\
\text { value dummy }\end{array}$ & $\begin{array}{l}\text { Larger market } \\
\text { share dummy }\end{array}$ \\
\hline \multirow[t]{2}{*}{ Treat dummy $\times \mathrm{C}$} & $0.202^{*}$ & $0.252^{* * *}$ \\
\hline & $(0.104)$ & $(0.0804)$ \\
\hline \multirow{2}{*}{ Treat dummy $\times \mathrm{C} \times$ Second outside directorships dummy } & -0.0651 & $-0.221^{* *}$ \\
\hline & $(0.148)$ & $(0.108)$ \\
\hline \multirow[t]{2}{*}{ Treat dummy $\times \mathrm{C} \times$ Third outside directorships dummy } & -0.123 & $-0.225^{* *}$ \\
\hline & $(0.144)$ & $(0.0896)$ \\
\hline \multirow[t]{2}{*}{ Treat dummy $\times \mathrm{C} \times$ Fourth outside directorships dummy } & -0.157 & -0.358 \\
\hline & $(0.139)$ & $(0.227)$ \\
\hline \multirow[t]{2}{*}{ Treat dummy $\times$ Second outside directorships dummy } & $-0.0951^{*}$ & 0.0312 \\
\hline & $(0.0564)$ & $(0.0713)$ \\
\hline \multirow[t]{2}{*}{ Treat dummy $\times$ Third outside directorships dummy } & -0.0239 & $0.104^{*}$ \\
\hline & $(0.0580)$ & $(0.0558)$ \\
\hline \multirow[t]{2}{*}{ Treat dummy $\times$ Fourth outside directorships dummy } & -0.00843 & 0.203 \\
\hline & $(0.0588)$ & $(0.207)$ \\
\hline \multirow[t]{2}{*}{$\mathrm{C} \times$ Second outside directorships dummy } & -0.00626 & -0.000745 \\
\hline & $(0.00573)$ & $(0.00669)$ \\
\hline \multirow[t]{2}{*}{$\mathrm{C} \times$ Third outside directorships dummy } & 0.00928 & 0.00866 \\
\hline & $(0.0105)$ & $(0.00939)$ \\
\hline \multirow[t]{2}{*}{$\mathrm{C} \times$ Fourth outside directorships dummy } & -0.00960 & 0.0440 \\
\hline & $(0.0197)$ & $(0.0720)$ \\
\hline \multirow[t]{2}{*}{ Treat dummy } & 0.0204 & $-0.0847^{*}$ \\
\hline & $(0.0427)$ & $(0.0435)$ \\
\hline \multirow[t]{2}{*}{$\mathrm{C}$} & $-0.00400^{* *}$ & $-0.00899^{* * *}$ \\
\hline & $(0.00193)$ & $(0.00202)$ \\
\hline \multirow[t]{2}{*}{ Second outside directorships dummy } & $0.00974^{* *}$ & 0.00739 \\
\hline & $(0.00431)$ & $(0.00574)$ \\
\hline \multirow[t]{2}{*}{ Third outside directorships dummy } & $-0.0161^{* *}$ & $-0.0203^{* * *}$ \\
\hline & $(0.00662)$ & $(0.00783)$ \\
\hline
\end{tabular}




\begin{tabular}{lcc}
\hline Fourth outside directorships dummy & 0.00296 & -0.0421 \\
$\Delta \operatorname{Ln}($ Assets $)$ & $(0.0148)$ & $(0.0720)$ \\
& $-0.118^{* * *}$ & $-0.118^{* * *}$ \\
$\Delta \mathrm{MB}$ & $(0.00747)$ & $(0.00731)$ \\
$\Delta(\mathrm{CAPX}+\mathrm{R} \& \mathrm{D}) / \operatorname{lag}(\mathrm{AT})$ & $0.00993^{* * *}$ & $0.00993^{* * *}$ \\
& $(0.00121)$ & $(0.00118)$ \\
$\Delta$ Sales growth rate & $0.0450^{* *}$ & $0.0462^{* *}$ \\
& $(0.0203)$ & $(0.0199)$ \\
$\Delta$ Ln(Per capita personal income) & $0.0280^{* * *}$ & $0.0291^{* * *}$ \\
& $(0.00462)$ & $(0.00453)$ \\
$\Delta$ Ln(Unemployment rate) & $-0.0604^{* *}$ & $-0.0608^{* *}$ \\
& $(0.0297)$ & $(0.0296)$ \\
Observations & -0.119 & -0.146 \\
R-squared & $(0.126)$ & $(0.126)$ \\
Industry-Year FE & 18,462 & 18,910 \\
Treat dummy $\times$ C + Treat dummy $\times$ C $\times$ Second outside & $0.1369^{* * *}$ & 0.293 \\
directorships dummy & & Yes \\
Treat dummy $\times$ C + Treat dummy $\times$ C $\times$ Third outside & $(0.0097)$ & 0.031 \\
directorships dummy & $0.079^{*}$ & $0.5722)$ \\
Treat dummy $\times$ C + Treat dummy $\times$ C $\times$ Fourth outside & $(0.0695)$ & 0.027 \\
directorships dummy & 0.045 & -0.106 \\
\hline
\end{tabular}




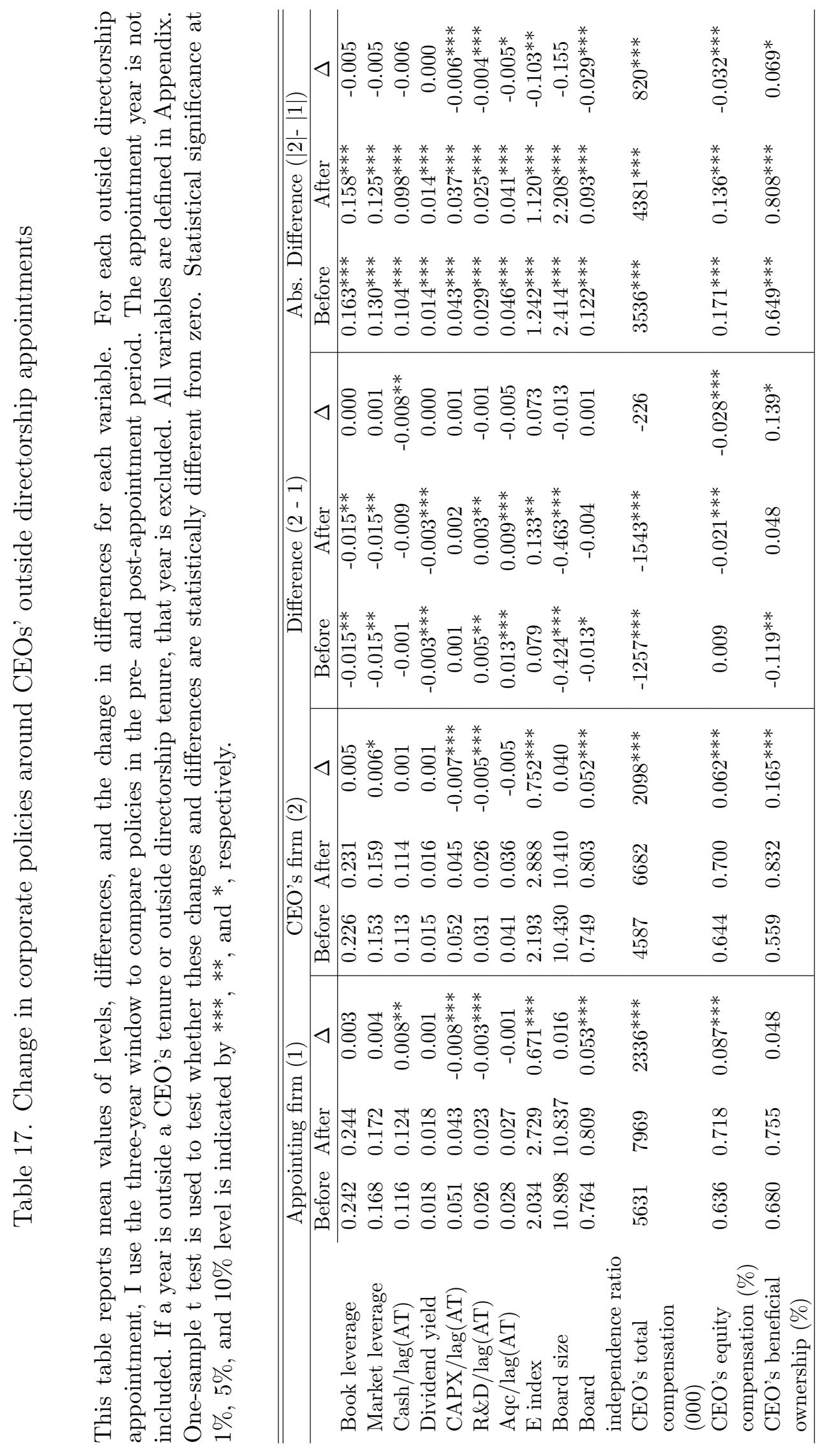


Table A1. Diff-in-Diff Panel OLS regression of ROA in paired sample

This table reports results from DID Panel OLS regressions. I pair each treated firm to all the control firms in the same SIC2 industry and in the same year. Dependent variable is $\Delta R O A_{t-3}$ to $t+3$, the average $R O A$ from year $\mathrm{t}+1$ to $\mathrm{t}+3$ minus the average $R O A$ from year $\mathrm{t}-3$ to $\mathrm{t}-1$ for each observation at year t. Sample of CEOs' outside director appointments is from 1999 to 2012. Treat dummy is an indicator for treated firms - firms whose CEO accepts a new outside directorship in year t. All other variables are defined in Appendix. All variables are winsorized at 1\% and 99\%. Standard errors are clustered at treated firm level. Statistical significance at 1\%, 5\%, and $10 \%$ level is indicated by $* * *, * *$, and $*$, respectively.

\begin{tabular}{|c|c|c|c|c|c|}
\hline Dependent variable & $(1)$ & $(2)$ & $\begin{array}{c}(3) \\
R O A_{t-3 \text { to }}\end{array}$ & (4) & $(5)$ \\
\hline Treat dummy & $\begin{array}{c}0.0133^{* * *} \\
(0.00355)\end{array}$ & $\begin{array}{c}0.00904^{* * *} \\
(0.00323)\end{array}$ & $\begin{array}{c}0.00510 \\
(0.00311)\end{array}$ & $\begin{array}{c}0.00296 \\
(0.00313)\end{array}$ & $\begin{array}{c}0.00431 \\
(0.00362)\end{array}$ \\
\hline$\Delta \operatorname{Ln}($ Assets $)$ & & & $\begin{array}{c}-0.109^{* * *} \\
(0.00605)\end{array}$ & $\begin{array}{l}-0.120^{* * *} \\
(0.00701)\end{array}$ & $\begin{array}{c}-0.120^{* * *} \\
(0.00718)\end{array}$ \\
\hline$\Delta \mathrm{MB}$ & & & $\begin{array}{c}0.0110^{* * *} \\
(0.00128)\end{array}$ & $\begin{array}{c}0.00942^{* * *} \\
(0.00121)\end{array}$ & $\begin{array}{c}0.00935^{* * *} \\
(0.00117)\end{array}$ \\
\hline$\Delta(\mathrm{CAPX}+\mathrm{R} \& \mathrm{D}) / \operatorname{lag}(\mathrm{AT})$ & & & & $\begin{array}{c}0.0478^{* *} \\
(0.0195)\end{array}$ & $\begin{array}{c}0.0467^{* *} \\
(0.0202)\end{array}$ \\
\hline$\Delta$ Sales growth rate & & & & $\begin{array}{c}0.0288^{* * *} \\
(0.00441)\end{array}$ & $\begin{array}{c}0.0293^{* * *} \\
(0.00459)\end{array}$ \\
\hline$\Delta \operatorname{Ln}($ Per capita personal income $)$ & & & & & $\begin{array}{l}-0.0415 \\
(0.0293)\end{array}$ \\
\hline$\Delta \operatorname{Ln}($ Unemployment rate $)$ & & & & & $\begin{array}{c}-0.0625 \\
(0.127)\end{array}$ \\
\hline Observations & 20,611 & 20,601 & 20,601 & 20,308 & 18,661 \\
\hline R-squared & 0.002 & 0.229 & 0.307 & 0.313 & 0.315 \\
\hline Industry-Year FE & No & Yes & Yes & Yes & Yes \\
\hline
\end{tabular}


Table A2. Multivariate analyses of CEO firms' announcement effect

This tables displays multivariate analyses of CEO firms' announcement effect of outside directorship appointments. Sample is from 1999 to 2012. Dependent variable is the market-adjusted cumulative abnormal returns (CARs) calculated over the $(-1,1)$ day event window, where $t=0$ is the announcement date. Larger market value (market share) dummy is an indicator for a larger appointment firm compared to CEO's firm measured by market value (market share). CEO's firm and the appointing firm are in the same industry based on Hoberg-Phillips classifications. Vertically related relation and informationally related relation are defined in the Appendix A. Degree and eigenvector are two centrality measures for an individual in the network obtained from BoardEx. New business relationship dummy is an indicator for a new business transaction that starts at CEOs' outside directorship appointment year or in the following three years. All other variables are defined in Appendix. Standard errors are corrected for heteroscedasticity. Statistical significance at $1 \%, 5 \%$, and $10 \%$ level is indicated by $* * *, * *$, and $*$, respectively.

Panel A

\begin{tabular}{lccc}
\hline \hline & \multicolumn{3}{c}{ Dependent variable: CAR(-1, 1) } \\
\hline Variable X & $\begin{array}{c}\text { Second outside } \\
\text { directorship } \\
\text { dummy }\end{array}$ & $\begin{array}{c}\text { Third outside } \\
\text { directorship } \\
\text { dummy }\end{array}$ & $\begin{array}{c}\text { Fourth outside } \\
\text { directorship } \\
\text { dummy }\end{array}$ \\
\hline X & $-0.762^{* *}$ & 0.0528 & \\
Ln(Assets) & $(0.366)$ & $(0.425)$ & -0.793 \\
MB ratio & -0.0401 & 0.00862 & $(0.679)$ \\
& $(0.140)$ & $(0.123)$ & -0.0118 \\
& 0.161 & 0.0454 & $0.121)$ \\
Observations & $(0.232)$ & $(0.185)$ & 0.0413 \\
R-squared & 410 & 482 & \\
Industry-Year FE & 0.118 & 0.082 & 500 \\
\hline
\end{tabular}




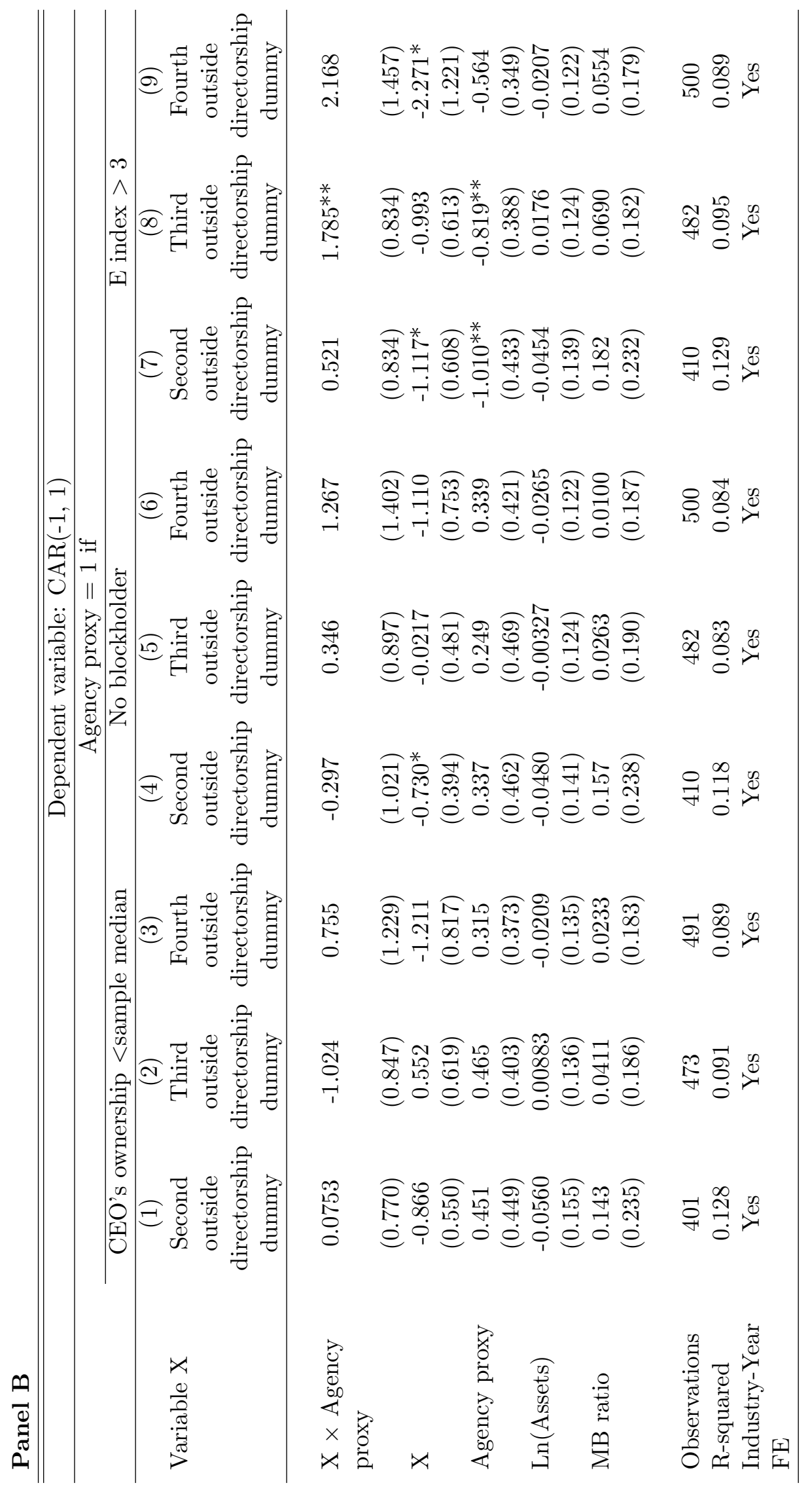




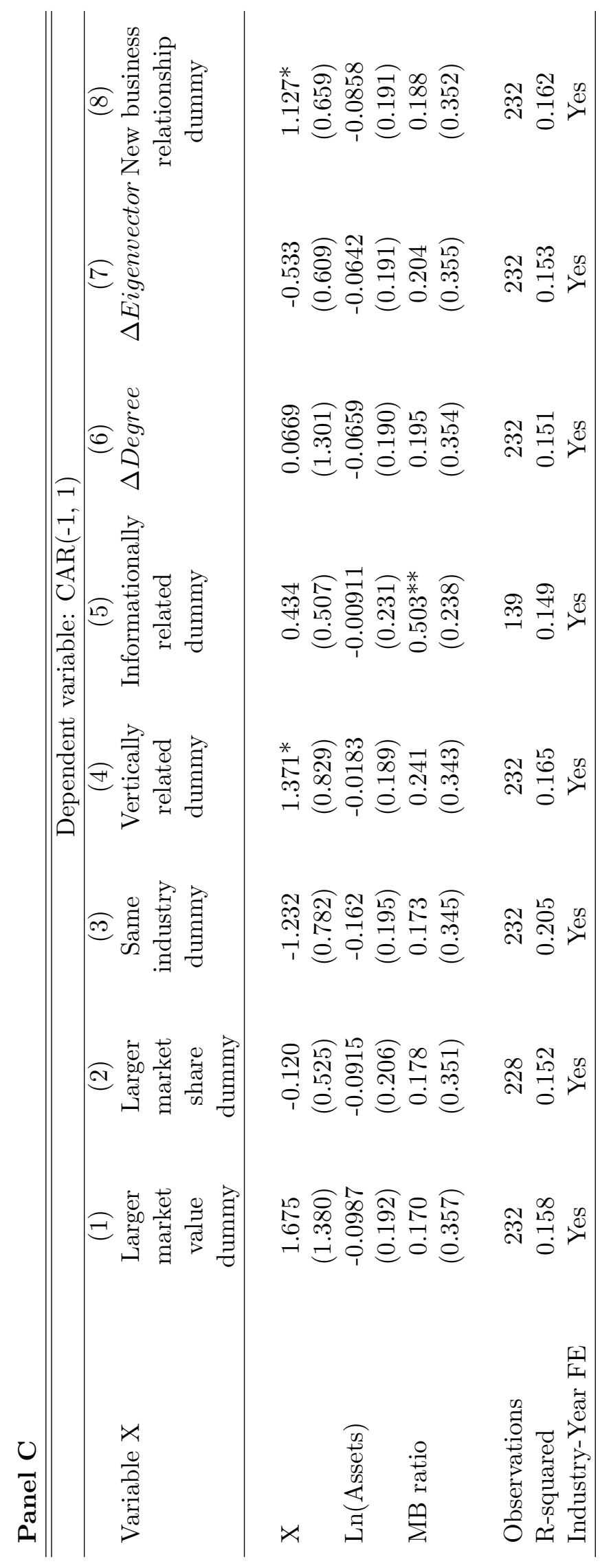


Table A3. Poisson regression of number of CEOs' outside directorships

This table displays Poisson regression results. Sample is from year 1999 to 2012. Dependent variable is \# CEO's existing outside directorships that are hand collected from appointing firms' proxy statements. All independent variables are for CEOs' own firms and are defined in Appendix. All variables are winsorized at $1 \%$ and $99 \%$. Standard errors are clustered at firm level. Statistical significance at $1 \%, 5 \%$, and $10 \%$ level is indicated by ${ }^{* * *},{ }^{* *}$, and ${ }^{*}$, respectively.

\begin{tabular}{|c|c|}
\hline Dependent variable & \# CEO's existing outside directorships \\
\hline $\operatorname{Ln}$ (Assets) & $\begin{array}{c}0.334^{* * *} \\
(0.0530)\end{array}$ \\
\hline Firm age & $\begin{array}{l}0.0141^{* *} \\
(0.00608)\end{array}$ \\
\hline MB ratio & $\begin{array}{l}-0.138^{*} \\
(0.0725)\end{array}$ \\
\hline$(\mathrm{CAPX}+\mathrm{R} \& \mathrm{D}) / \operatorname{lag}(\mathrm{AT})$ & $\begin{array}{l}0.0989 \\
(1.030)\end{array}$ \\
\hline Sales growth rate & $\begin{array}{c}-0.707^{* * *} \\
(0.220)\end{array}$ \\
\hline $\mathrm{ROA}$ & $\begin{array}{c}0.246 \\
(0.609)\end{array}$ \\
\hline Stock return & $\begin{array}{c}0.145 \\
(0.103)\end{array}$ \\
\hline CEO's age & $\begin{array}{c}0.0321^{* * *} \\
(0.0106)\end{array}$ \\
\hline CEO's age $>62$ dummy & $\begin{array}{l}-0.380^{*} \\
(0.202)\end{array}$ \\
\hline Chairman dummy & $\begin{array}{l}0.0629 \\
(0.140)\end{array}$ \\
\hline Board size & $\begin{array}{l}0.00875 \\
(0.0229)\end{array}$ \\
\hline Board independence ratio & $\begin{array}{c}0.571 \\
(0.486)\end{array}$ \\
\hline CEO's beneficial ownership & $\begin{array}{c}0.0136 \\
(0.00840)\end{array}$ \\
\hline CEO's beneficial ownership 1-5\% dummy & $\begin{array}{l}0.0570 \\
(0.162)\end{array}$ \\
\hline CEO's beneficial ownership 5-10\% dummy & $\begin{array}{c}0.221 \\
(0.266)\end{array}$ \\
\hline CEO's beneficial ownership 10-20\% dummy & $\begin{array}{l}-0.352 \\
(0.386)\end{array}$ \\
\hline CEO's beneficial ownership $>20 \%$ dummy & $\begin{array}{c}-1.105^{* *} \\
(0.504)\end{array}$ \\
\hline Observations & 15,682 \\
\hline Pseudo R-squared & 0.1562 \\
\hline Industry-Year FE & Yes \\
\hline
\end{tabular}


Table A4. Regression results for Non-S\&P 1500 firms

This table reports the main regression results in the paper for Non-S\&P 1500 firms. $\Delta R O A_{t-3}$ to $t+3$ is the average $R O A$ from year $\mathrm{t}+1$ to $\mathrm{t}+3$ minus the average $R O A$ from year $\mathrm{t}-3$ to $\mathrm{t}-1$ for each observation at year t. Treat dummy is an indicator for treated firms - firms whose CEO accepts a new outside directorship in year t. All other variables are defined in Appendix. All variables are winsorized at $1 \%$ and $99 \%$. Standard errors are clustered at treated firm level. Statistical significance at $1 \%, 5 \%$, and $10 \%$ level is indicated by ${ }^{* * *},{ }^{* *}$, and ${ }^{*}$, respectively.

Panel A. Average performance effect

\begin{tabular}{lc}
\hline \hline Dependent variable & $\Delta R O A_{t-3}$ to $t+3$ \\
\hline & \\
Treat dummy & -0.201 \\
& $(0.354)$ \\
$\Delta \operatorname{Ln}($ Assets $)$ & $0.105^{* * *}$ \\
$\Delta \mathrm{MB}$ & $(0.0101)$ \\
& $-0.0125^{* * *}$ \\
$\Delta(\mathrm{CAPX}+\mathrm{R} \& \mathrm{D}) / \operatorname{lag}(\mathrm{AT})$ & $(0.00170)$ \\
& $-0.0989^{* * *}$ \\
$\Delta$ Sales growth rate & $(0.0223)$ \\
& $-0.0056^{* * *}$ \\
$\Delta \mathrm{Ln}($ Per capita personal income) & $(0.00207)$ \\
& $0.227^{* * *}$ \\
$\Delta$ Unemployment rate & $(0.0555)$ \\
& $0.970^{* * *}$ \\
& $(0.254)$ \\
Observations & 47,253 \\
R-squared & 0.055 \\
Industry-Year FE & Yes \\
\hline
\end{tabular}


Panel B. Cross-sectional variations in performance effect

\begin{tabular}{|c|c|c|c|c|c|}
\hline \multirow[b]{3}{*}{ Variable $\mathrm{C}$} & \multicolumn{5}{|c|}{ Dependent variable: $\Delta R O A_{t-3}$ to $t+3$} \\
\hline & $(1)$ & $(2)$ & $(3)$ & $(4)$ & $(5)$ \\
\hline & $\begin{array}{c}\text { Second } \\
\text { outside } \\
\text { directorship } \\
\text { dummy }\end{array}$ & $\begin{array}{c}\text { Third } \\
\text { outside } \\
\text { directorship } \\
\text { dummy }\end{array}$ & $\begin{array}{c}\text { Larger } \\
\text { market } \\
\text { value } \\
\text { dummy }\end{array}$ & $\begin{array}{c}\text { Larger } \\
\text { market } \\
\text { share } \\
\text { dummy }\end{array}$ & $\begin{array}{l}\text { Vertically } \\
\text { related } \\
\text { dummy }\end{array}$ \\
\hline Treat dummy $\times \mathrm{C}$ & $\begin{array}{l}0.0247 \\
(0.520)\end{array}$ & $\begin{array}{l}0.0919 \\
(0.406)\end{array}$ & $\begin{array}{l}-0.280 \\
(0.728)\end{array}$ & $\begin{array}{l}-0.229 \\
(0.576)\end{array}$ & $\begin{array}{c}0.747 \\
(1.741)\end{array}$ \\
\hline Treat dummy & $\begin{array}{l}-0.222 \\
(0.476)\end{array}$ & $\begin{array}{l}-0.215 \\
(0.395)\end{array}$ & $\begin{array}{l}-0.178 \\
(0.180)\end{array}$ & $\begin{array}{r}-0.0296 \\
(0.122)\end{array}$ & $\begin{array}{l}-0.267 \\
(0.358)\end{array}$ \\
\hline $\mathrm{C}$ & $\begin{array}{l}0.00727 \\
(0.0235)\end{array}$ & $\begin{array}{l}-0.00705 \\
(0.0238)\end{array}$ & $\begin{array}{c}0.0207^{* * *} \\
(0.00477)\end{array}$ & $\begin{array}{c}0.0331^{* * *} \\
(0.00811)\end{array}$ & $\begin{array}{c}0.00119 \\
(0.00608)\end{array}$ \\
\hline$\Delta \operatorname{Ln}($ Assets $)$ & $\begin{array}{l}0.105^{* * *} \\
(0.0102)\end{array}$ & $\begin{array}{c}0.105^{* * *} \\
(0.0102)\end{array}$ & $\begin{array}{c}0.106^{* * *} \\
(0.0102)\end{array}$ & $\begin{array}{l}0.101^{* * *} \\
(0.0102)\end{array}$ & $\begin{array}{l}0.105^{* * * *} \\
(0.0101)\end{array}$ \\
\hline$\Delta \mathrm{MB}$ & $\begin{array}{c}-0.0125^{* * *} \\
(0.00170)\end{array}$ & $\begin{array}{c}-0.0125^{* * *} \\
(0.00170)\end{array}$ & $\begin{array}{c}-0.0127^{* * * *} \\
(0.00171)\end{array}$ & $\begin{array}{c}-0.0129^{* * *} \\
(0.00169)\end{array}$ & $\begin{array}{c}-0.0126^{* * *} \\
(0.00170)\end{array}$ \\
\hline$\Delta(\mathrm{CAPX}+\mathrm{R} \& \mathrm{D}) / \operatorname{lag}(\mathrm{AT})$ & $\begin{array}{c}-0.0989^{* * *} \\
(0.0222)\end{array}$ & $\begin{array}{c}-0.0989 * * * \\
(0.0222)\end{array}$ & $\begin{array}{c}-0.103^{* * *} \\
(0.0224)\end{array}$ & $\begin{array}{c}-0.0952^{* * *} \\
(0.0223)\end{array}$ & $\begin{array}{c}-0.0989 * * * \\
(0.0223)\end{array}$ \\
\hline$\Delta$ Sales growth rate & $\begin{array}{c}-0.00552^{* * *} \\
(0.00207)\end{array}$ & $\begin{array}{c}-0.00557^{* * *} \\
(0.00207)\end{array}$ & $\begin{array}{c}-0.00584^{* * *} \\
(0.00210)\end{array}$ & $\begin{array}{c}-0.00600^{* * *} \\
(0.00212)\end{array}$ & $\begin{array}{c}-0.00561^{* * *} \\
(0.00207)\end{array}$ \\
\hline$\Delta \operatorname{Ln}($ Per capita personal income $)$ & $\begin{array}{c}0.228^{* * *} \\
(0.0560)\end{array}$ & $\begin{array}{c}0.227^{* * *} \\
(0.0555)\end{array}$ & $\begin{array}{c}0.231^{* * *} \\
(0.0562)\end{array}$ & $\begin{array}{c}0.197^{* * *} \\
(0.0545)\end{array}$ & $\begin{array}{c}0.228^{* * *} \\
(0.0553)\end{array}$ \\
\hline$\Delta$ Unemployment rate & $\begin{array}{c}0.974^{* * *} \\
(0.254)\end{array}$ & $\begin{array}{c}0.970^{* * *} \\
(0.254)\end{array}$ & $\begin{array}{c}0.950^{* * *} \\
(0.262)\end{array}$ & $\begin{array}{c}0.938^{* * *} \\
(0.244)\end{array}$ & $\begin{array}{c}0.947^{* * *} \\
(0.262)\end{array}$ \\
\hline Observations & 47,197 & 47,249 & 45,927 & 46,950 & 47,253 \\
\hline R-squared & 0.055 & 0.055 & 0.053 & 0.057 & 0.054 \\
\hline Industry-Year FE & Yes & Yes & Yes & Yes & Yes \\
\hline
\end{tabular}

